Utah State University

DigitalCommons@USU

$5-1988$

\title{
The Effects of the Spatial Pattern of Defoliation on Regrowth of a Tussock Grass
}

Warren G. Gold

Utah State University

Follow this and additional works at: https://digitalcommons.usu.edu/etd

Part of the Plant Sciences Commons

\section{Recommended Citation}

Gold, Warren G., "The Effects of the Spatial Pattern of Defoliation on Regrowth of a Tussock Grass" (1988). All Graduate Theses and Dissertations. 6458.

https://digitalcommons.usu.edu/etd/6458

This Dissertation is brought to you for free and open access by the Graduate Studies at DigitalCommons@USU. It has been accepted for inclusion in All Graduate Theses and Dissertations by an authorized administrator of DigitalCommons@USU. For more information, please contact digitalcommons@usu.edu.

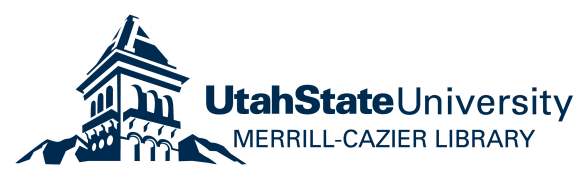


THE EFFECTS OF THE SPATIAL PATTERN OF DEFOLIATION ON REGROWTH OF A TUSSOCK GRASS

by

$$
\text { Warren G. Gold }
$$

A dissertation submitted in partial fulfillment of the requirements for the degree

of

DOCTOR OF PHILOSOPHY

in

Range Ecology

Approved:

UTAH STATE UNIVERSITY

Logan, Utah 


\section{ACKNOWLEDGEMENTS}

This research was supported by a National science Foundation grant to Dr. Martyn Caldwell and Dr. Jim Richards (DEB 8207171) and by a National Science Foundation graduate fellowship to myself. This financial support is gratefully acknowledged.

I would like to thank Dr. Caldwell for his thoughtful guidance, encouragement, and faith in my abilities. He always provided an open door for discussion and a critical eye for my work. I appreciate the helpful discussions and review of this work by Dr. Jim Hansen, Dr. Doug Johnson, Dr. Jim MacMahon, Dr. Keith Mott, and Dr. Fred Provenza. Dr. Don Sisson provided valuable statistical advice. Dr. Richards also provided a number of valuable insights and suggestions on this research.

Michelle Thompson, Kathe Walter, Walid Al-Jallad, Hussein Kalakish, Christian Larsen, and Julia Gold helped with the collection of the field data for many long hours in every kind of weather. Their reliable help was invaluable to the completion of this project. I am also deeply grateful to Halldor Thorgiersson, Dave Eissenstat, Bret Olson, Paul Barnes, Steve Link, Bob Nowak, Steve Flint, Ron Ryel, Carlos Busso, John Manwaring, and Peter Jordan for a tremendous amount of valuable advice and assistance, as well as their friendship. Gary Harris and Charlie Ashurst designed, built, maintained, and repaired almost every piece of equiptment I used. This research could certainly not 
have been done without their expert help. I am thankful to Robin scherting for helping me unwind numerous bureaucratic tangles.

Ramona Rukavina provided some important field help and vital friendship. The personal support of Jeff and Maria Norton, scott Mills, Keith Marine, Ron squibb, Billy Helprin, and Alan Carpenter has been crucial to my survival and growth. I would also like to thank my mother and father, and my sister and brothers for their patient support during my long tenure here.

Finally, my wife Julia has always stood by me through good and bad, through work and adventure these past 5 years. I am forever grateful for her love and companionship during this project and in the future. 
TABLE OF CONTENTS

Page

ACKNOWLEDGEMENTS

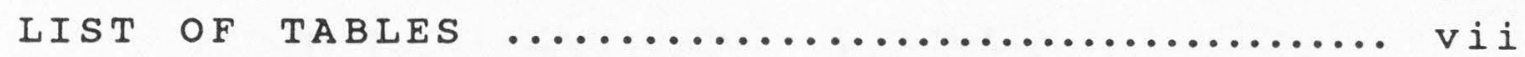

LIST OF FIGURES $\ldots \ldots \ldots \ldots \ldots \ldots \ldots \ldots \ldots \ldots \ldots \ldots \ldots \ldots \ldots \ldots \ldots$

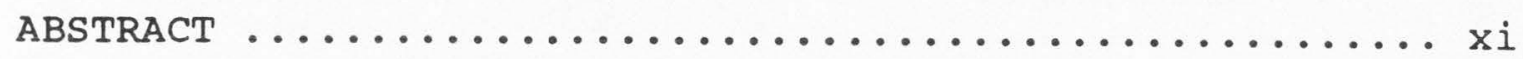

Chapter

I. OVERVIEW $\ldots \ldots \ldots \ldots \ldots \ldots \ldots \ldots \ldots \ldots \ldots \ldots \ldots \ldots \ldots \ldots \ldots$

II. THE EFFECTS OF THE SPATIAL PATTERN OF

DEFOLIATION ON REGROWTH OF A TUSSOCK GRASS:

I. GROWTH RESPONSES ................... 5

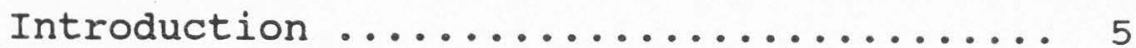

Methods ......................... 8

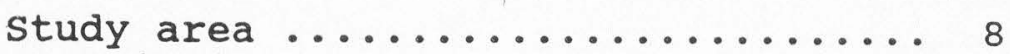

Defoliations ..................... 9

Foliage surface area measurement .... 11

Aboveground biomass production ...... 12

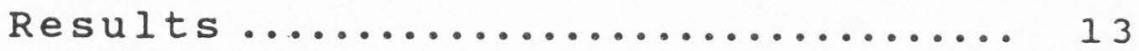

Defoliation before apical meristem

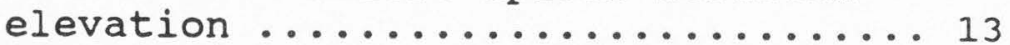

Defoliation after apical meristem

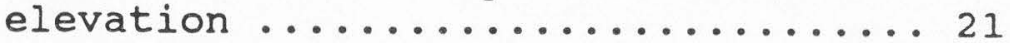

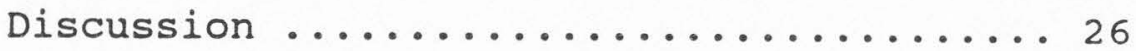

III. THE EFFECTS OF THE SPATIAL PATTERN OF

DEFOLIATION ON REGROWTH OF A TUSSOCK GRASS:

II. CANOPY GAS EXCHANGE ............... 33

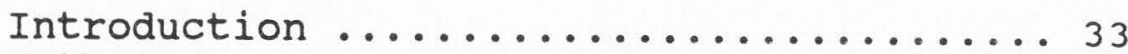

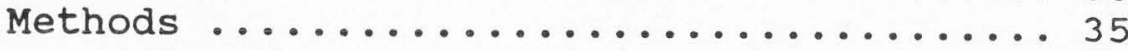

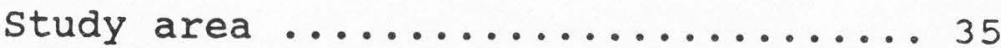

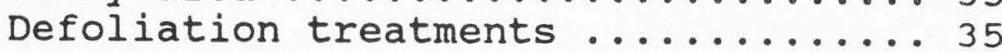

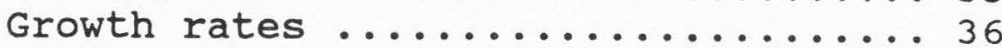

Canopy gas exchange ............. 37

Results ......................4 4

Canopy $\mathrm{CO}_{2}$ exchange ...........4 41 
TABLE OF CONTENTS (continued)

Page

Water-use efficiency .......... 47

Conductance and intercellular

$\mathrm{CO}_{2}$ concentration ...........4 47

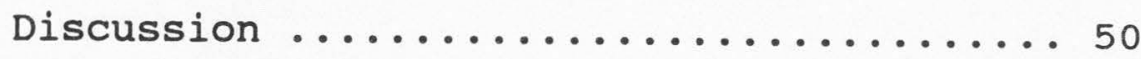

Defoliation spatial pattern and

canopy $\mathrm{CO}_{2}$ exchange ........... 50

Water-use efficiency and regrowth ... 55

Conductance and $\mathrm{CO}_{2}$ fixation ...... 57

Whole-tussock carbon gain ........ 59

IV. THE EFFECTS OF THE SPATIAL PATTERN OF

DEFOLIATION ON REGROWTH OF A TUSSOCK GRASS:

III. PHOTOSYNTHESIS, CANOPY STRUCTURE,

AND LIGHT INTERCEPTION ................61

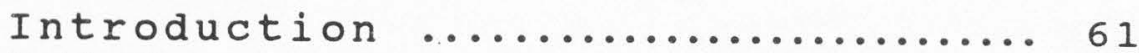

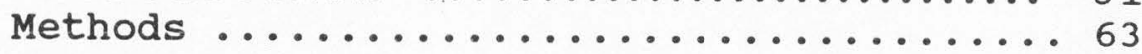

study area .....................63 63

Defoliation treatments ...............6 63

Canopy gas exchange ............. 64

Canopy structure ..............667

Light interception ............. 68

Foliage age structure ...........71

Results ........................ 71

Photosynthetic characteristics ..... 71

Canopy structure ............. 75

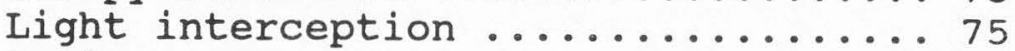

Foliage age structure .......... 77

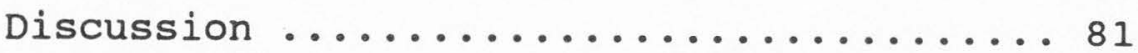

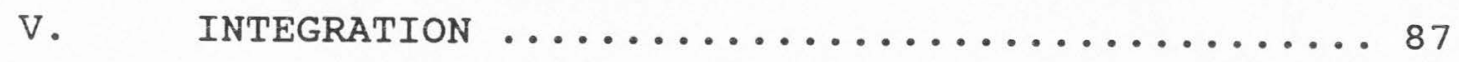

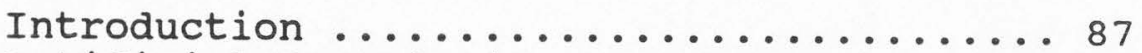

Artificial defoliation and actual

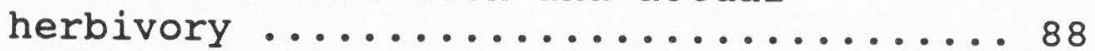

Herbivores and spatial patterns of

defoliation of Agropyron desertorum ....99 91

Spatial scales of herbivore selectivity .. 95

Compensatory photosynthesis: problems

of scale ..................... 99

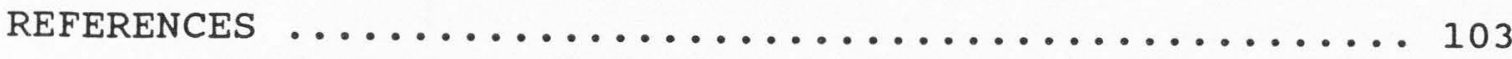


TABLE OF CONTENTS (continued)

Page

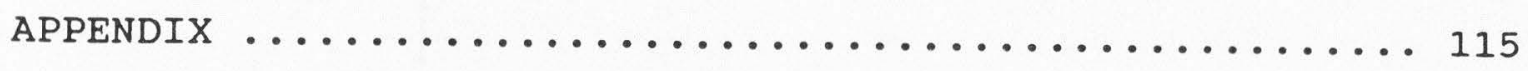

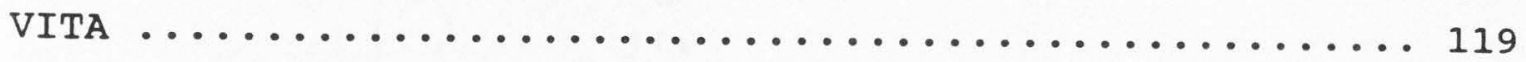


1. Percentage of total green foliage area removed from tussocks by the defoliation treatments. The numbers in parentheses are the standard error of the mean. Different letters indicate significant differences $(\mathrm{P}<.05)$ among means $(\mathrm{n}=6$ or 7$)$ within

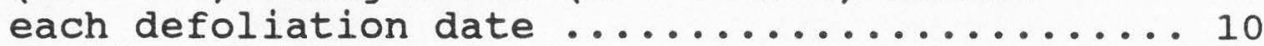

2. Experimental details and timetable ......... 10

3. Total foliage area specific growth rates during a three-week period prior to clipping in the $1985 \mathrm{mid}-\mathrm{May}$ clipping experiment. The numbers in parentheses are the standard error of the mean $(n=7)$. Different letters indicate significant differences $(P<.05)$ among

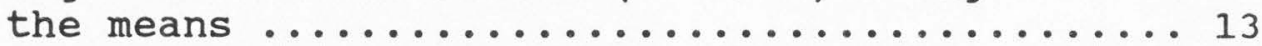

4. Conductance to water vapor $\left(g_{\mathrm{w}}\right)$ and intercellular $\mathrm{CO}_{2}$ concentration $\left(\mathrm{C}_{i}\right)$ for tussocks averaged over the middle

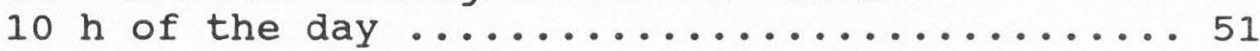

5. Light-saturated photosynthetic rates $\left(\mathrm{P}_{2000}\right)$ and quantum efficiencies (QE) from smith equations fitted to diurnal gas exchange data ...................66

6. Relative changes in light-saturated photosynthesis $\left(\mathrm{P}_{2000}\right)$ and quantum efficiency (QE) following defoliation......... 
1. Specific growth rates of green foliage area for two sequential regrowth periods

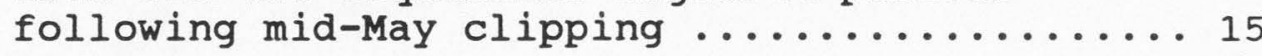

2. Specific growth rates of (a) leaf blade area and (b) leaf sheath area for two sequential regrowth periods following mid-May

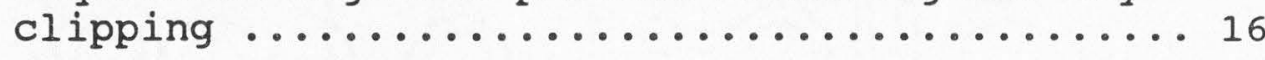

3. Rates of production and senescence of green foliage area for two sequential regrowth periods following mid-May clipping ......... 18

4. (a) Peak standing crop and (b) total-season aboveground biomass production relative to the green foliage area of the tussock prior to clipping. Tussocks were clipped in mid May .... 19

5. Specific growth rates of (a) green foliage area, (b) leaf blade area and (c) leaf sheath area following late-May clipping in $1985 \ldots 22$

6. Production and senescence rates of green foliage area following late-May clipping

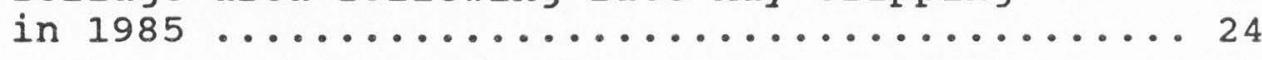

7. (a) Peak standing crop and (b) total-season aboveground biomass production relative to the green foliage area of the tussock prior to clipping. Tussocks were clipped in late

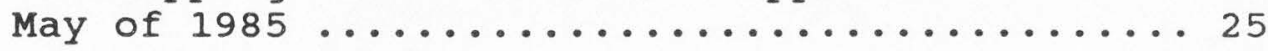

8. The relationship between $24-\mathrm{h}$ net carbon gain the day after clipping and the specific growth rate of each of the 12 tussocks over the first $14 \mathrm{~d}$ following defoliation ........442

9. The fractional change following defoliation (postclip/preclip) in (a) $24-\mathrm{h}$ net carbon gain (mol $\left.\mathrm{CO}_{2} \mathrm{~m}^{-2}\right),(\mathrm{b})$ daytime net $\mathrm{CO}_{2}$ uptake (mol $\mathrm{m}^{-2}$ ), and (c) nighttime $\mathrm{CO}_{2}$ efflux (mol $\mathrm{m}^{-2}$

10. Percent change in daytime $\mathrm{CO}_{2}$ uptake from predefoliation measurements for (a) tussock assimilation per unit foliage area (mol $\mathrm{CO}_{2} \mathrm{~m}^{-2}$ ) and (b) wholetussock assimilation $\left(\mathrm{mol} \mathrm{CO}_{2}\right) \ldots \ldots \ldots . \ldots . \ldots 4$ 
LIST OF FIGURES (continued)

Figure

Page

11 .

The fractional change in daytime water-

use efficiency (WUE $=C E R_{d} / E_{d}$ )

following defoliation of treatment

tussocks (postclip/preclip) (upper

panel). The association between WUE and

the specific growth rates of each of the 12

tussocks over the first $14 \mathrm{~d}$ following

clipping is shown in the lower panel .......4 48

12. The fractional change following defoliation

(postclip/preclip) in (a) daytime water

vapor loss ( $\mathrm{mol} \mathrm{m} \mathrm{m}^{-2}$ ), (b) conductance

to water vapor (mmol $\mathrm{m}^{-2} \mathrm{~s}^{-1}$ ), and

(c) intercellular $\mathrm{CO}_{2}$ concentration (ul $1^{-1}$ ) . 49

13. The correlation between two estimates of

tussock light interception calculated

using different measuresof the proportion

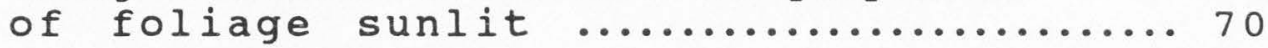

14. Net photosynthesis of tussocks (a) before clipping and (b) after clipping as a

function of the natural diurnal variation

in photosynthetic photon flux density .......72

15. The relationship between the relative change (postclip/preclip) in $\mathrm{P}_{2000}$ and the relative change in $C R_{d}$

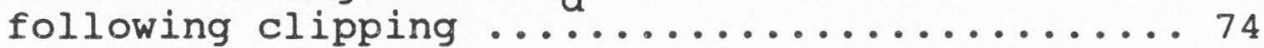

16. The vertical distribution of tussock green foliage area in $5 \mathrm{~cm}$ increments from the soil surface ......................... 76

17. The relationship between the relative change in the proportion of tussock foliage directly illuminated and the relative change in $\mathrm{P}_{2000}$

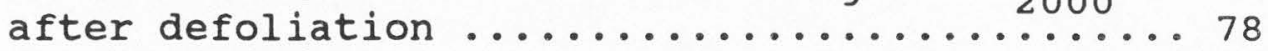

18. The relationship between the green foliage area of a tussock and the calculated interception of photosynthetic photon flux by the tussock at solar noon ................79

19. The relative amount of tussock foliage area at different leaf positions prior to clipping and 1,14 , and 28 d after clipping ... 80 


\section{LIST OF FIGURES (continued)}

Figure

20 .

Leaf blade area (one side) as a function

of the product of blade length and maximum width for intact leaf blades ............. 116

21. Leaf blade area (one side) as a function of the product of blade length and maximum width for clipped leaf blades ........... 117

22. Leaf blade area (one side) as a function of blade length for rolled leaf blades ........ 118 


\title{
ABSTRACT
}

The Effects of the Spatial Pattern of Defoliation on Regrowth of a Tussock Grass

by

\author{
Warren G. Gold, Doctor of Philosophy \\ Utah State University, 1988
}

Major Professor: Dr. Martyn M. Caldwell

Department: Range Science

The influence of the spatial pattern of foliage removal on regrowth was investigated in the field with a tussock grass, Agropyron desertorum. Tussocks were hand clipped in different spatial patterns that represented extremes of defoliation patterns which could be inflicted by natural herbivores. All defoliated tussocks exhibited increases in specific growth rates following clipping in mid-May. When foliage was removed from the upper portion of the canopy (younger foliage), regrowth rates and season-long aboveground biomass production were less than if the same amount of foliage was removed from low in the canopy (older foliage). The spatial pattern of defoliation also influenced tussock regrowth in a late-May clipping experiment, but differences in the effects of the clipping patterns were associated with the removal of apical meristems rather than with the age or location of foliage removed.

Changes in tussock carbon dioxide and water vapor 
exchange that were associated with changes in growth following mid-May clipping were explored. All clipped tussocks showed increases in integrated daytime carbon dioxide uptake per unit foliage area after defoliation. Differences among treatments in the response of net daytime carbon gain during the first 24 hours after clipping corresponded well with differences in tussock regrowth over a 14-day period following clipping. Increased carbon gain of clipped tussocks was associated with increases in tussock water vapor conductance and intercellular carbon dioxide concentration, and decreases in the ratio of carbon dioxide uptake to water vapor loss.

Differences among treatments in daytime carbon gain and regrowth were paralleled by the response of instantaneous rates of light-saturated net photosynthesis for entire tussocks. Defoliation increased the proportion of foliage directly illuminated within the tussock at solar noon. Changes in the fraction of sunlit foliage and the relative amounts of different-aged foliage in tussock canopies were correlated with the responses of light-saturated photosynthesis. Thus, the effects of the spatial pattern of foliage removal on canopy light microclimate and the age of remaining foliage had important implications for carbon gain and regrowth of tussocks following mid-May defoliation. 
CHAPTER I

\section{OVERVIEW}

Many aspects of foliage removal can affect plant response to defoliation. The amount of foliage removed is often negatively correlated with plant production (Harper 1977, Dyer et al. 1982), although a small amount of defoliation may increase production in certain grasses (McNaughton 1979a, Dyer et al. 1982). The timing and frequency of herbivore defoliation can also influence the response of a plant to foliage removal (e.g. Binnie et al. 1980, Ludlow and Charles-Edwards 1980). However, one aspect of defoliation that has received little attention is the spatial pattern in which foliage is removed from a plant canopy. Selection among plant parts within a canopy by an herbivore can result in particular spatial patterns of foliage removal from the plant. Various spatial patterns of defoliation can also result from the random removal of foliage from a plant.

The tussock grass, Agropyron desertorum, is exposed to a variety of herbivores during the early-spring to midsummer growing season in the Intermountain region of North America (see chapter V). These herbivores may remove foliage from A. deserertorum tussocks in different spatial patterns.

In Chapter II, I report on a field investigation that examined the growth responses of $\underline{A}$. desertorum tussocks to 
different patterns of foliage removal. The production of new foliage and senescence of older foliage was followed for four weeks after tussocks were hand clipped in different spatial patterns. Season-long aboveground biomass production was also measured to evaluate the effects of these defoliation patterns.

The results indicated that the pattern of foliage removal had a substantial influence on tussock regrowth. Also, the relative effects of different defoliation patterns interacted strongly with the timing of defoliation. For a late-May defoliation, differences in the influence of clipping patterns on regrowth were associated with effects of defoliation on apical meristems. However, the differences in regrowth caused by clipping patterns in a mid-May experiment could not be attributed to effects on apical meristems. When apical meristems were left intact, as in the mid-May clipping experiment, foliage regrowth may have been constrained by current carbon dioxide $\left(\mathrm{CO}_{2}\right)$ assimilation (e.g. Richards and Caldwell 1985). Therefore, I investigated the effect of the clipping patterns on daily net carbon gain of tussocks in an mid-May clipping experiment (Chapter III). The $\mathrm{CO}_{2}$ and water vapor exchange of entire tussocks was measured for $24-\mathrm{h}$ periods immediately before and after defoliation. Responses of integrated daytime $\mathrm{CO}_{2}$ uptake and nighttime $\mathrm{CO}_{2}$ loss to different defoliation patterns were compared with responses of foliage regrowth. The relationship between foliage regrowth and the 
water-use efficiency of $\mathrm{CO}_{2}$ uptake was also examined.

The results from the tussock gas exchange experiment indicated that the spatial pattern of defoliation affected tussock daytime $\mathrm{CO}_{2}$ uptake. The responses of $\mathrm{CO}_{2}$ uptake were correlated with regrowth responses. Therefore, I examined factors affected by the defoliation patterns which could cause differences in tussock $\mathrm{CO}_{2}$ uptake and regrowth (Chapter IV). The physical structure and light interception of tussock canopies was measured immediately before and after defoliation. The balance of sunlit and shaded foliage within the tussocks was also measured. Finally, changes in the relative amounts of different-aged foliage (foliage age structure) in tussocks were quantified.

In the last chapter, I examine the general relationship between these clipping studies and actual herbivory. In particular, the defoliation of $\underline{A}$. desesertor $\underline{\text { deu }}$ by common herbivores of the Intermountain region is discussed in relation to the results from the preceding chapters. The studies in chapters II, III, and IV focus on the response of a single plant to the selective removal of foliage within the canopy of that plant. The final chapter also considers the implications of selective defoliation at other spatial scales (e.g. selection among plant species) and the effects of such selectivity on plant populations and communities as well as individual plants. Finally, I examine the relationship among compensatory increases in single-leaf photosynthesis following defoliation, whole tussock 
compensatory photosynthesis (e.g. Chapter III), and the production of new tussock foliage following defoliation. 
CHAPTER II

THE EFFECTS OF THE SPATIAL PATTERN OF DEFOLIATION

ON REGROWTH OF A TUSSOCK GRASS:

I. GROWTH RESPONSES

Introduction

The relative contribution of a leaf to the carbon economy of the plant changes substantially over the lifetime of that leaf (Mooney and Gulmon 1982). Thus, changes in the age structure of leaves imposed by partial defoliation should have an influence on plant regrowth. Removal of younger foliage would be expected to be more detrimental to plant carbon balance and regrowth than removal of older foliage because younger foliage typically has higher maximal rates of photosynthesis and higher light saturation for photosynthesis (Janzen 1979, Dirzo 1984). Removal of younger leaves has been shown experimentally to be more detrimental than removal of older leaves to crop production (stickler and Pauli 1961, Brown et al. 1966) and growth of conifers (Kulman 1965) and understory palms (Dirzo 1984).

There has been considerable discussion in the literature recently regarding the effects of defoliation on the age structure of plant foliage (Janzen 1979, McKey 1979, Caldwell 1984, Dirzo 1984, Hartnett and Bazzaz 1986). Hartnett and Bazzaz (1986) argued that the relative values of different-aged leaves could be quantified and that the effects of herbivory on a plant would be influenced by the 
age of the leaves removed. However, many other factors beside individual leaf physiological status affect plant carbon balance and growth. The removal of certain plant parts, such as meristematic tissue, may have detrimental effects far out of proportion to the small amount of tissue removed (Briske 1986). Even when current carbon dioxide $\left(\mathrm{CO}_{2}\right)$ fixation limits regrowth (e.g. Richards and Caldwell 1985), it may be difficult to predict the effects of removing different-aged foliage because of concomitant changes in canopy structure and light interception. Canopy structure and light interception have a major influence on $\mathrm{CO}_{2}$ assimilation (Monsi et al. 1973, Koerner 1982, Ludlow et al. 1982, Joggi et al. 1983) and growth (Rhodes 1971, Ludlow and Charles-Edwards 1980, Fliervoet and werger 1984) of various plants.

Grasses in many semiarid regions have a tussock growth form, appearing as dense islands of foliage during the spring growing season (Caldwell et al. 1983a). Because of the substantial amount of shaded foliage within these tussocks, changes in canopy structure and light interception may have considerable importance to regrowth.

Individual grass tussocks can be defoliated in a variety of spatial patterns by herbivores. Large ungulates defoliate tussock grasses from above, generally removing younger foliage which occupies the upper portion of the canopy. Insect herbivores can remove foliage in various parts of a tussock canopy. For example, Hansen (1987) found 


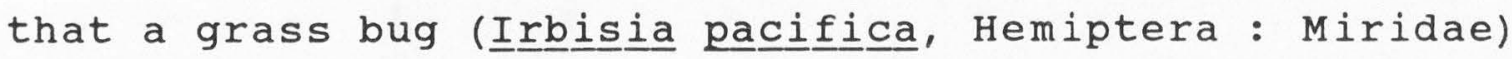
concentrates its feeding on intermediate-aged leaf blades of some tussock grasses. Changes in the age structure of tussock foliage following defoliation may be important for regrowth. Nowak and Caldwell (1984) measured considerable differences in the photosynthetic characteristics of different-aged foliage within tussocks of two Agropyron species. The implications of the spatial pattern of defoliation for foliage age structure, canopy structure, and subsequent regrowth have not been directly studied.

In this study, I quantified the effect of different defoliation patterns on the regrowth rates, peak standing crop, and aboveground biomass production of a semiaridregion tussock grass, Agropyron desertorum (Fisch. ex Link) Schult. Agroopyron deserertor $\underline{\text { de }}$ m is a perennial tussock grass introduced into the Intermountain Region of North America to improve rangeland degraded from overgrazing. From growth initiation in the early spring to summer dormancy, $\underline{A}$. desertorum is exposed to a variety of herbivores. Following

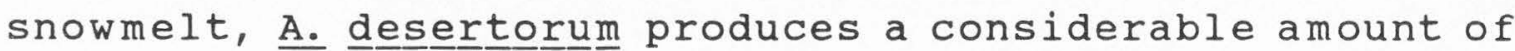
foliage while still in a culmless state, resulting in a compact, dense tussock. The tussocks are relatively tolerant of defoliation in this state because rapid regrowth can occur from active apical and intercalary meristems located near the soil surface. Later in the spring, however, the apical meristems are elevated and become susceptible to removal by large grazers. The removal of 
apical meristems results in a large decrease in the rate of foliage regrowth (Richards and Caldwell 1985). Defoliation by leaf-feeding insects would not affect these meristems. The effects of different spatial patterns of defoliation on tussock regrowth may vary with the timing of defoliation because of changes in the different states of meristem activity and changes in the susceptibility of apical meristems to removal. In this study, the regrowth of $\underline{A}$. dese토으므 was examined in the field following artificial defoliation in different spatial patterns, both before and after apical meristem elevation.

Methods

\section{Study area}

The experiments were carried out in a field plot at the Green Canyon Ecology center in northern Utah (42 N latitude, $1460 \mathrm{~m}$ above sea level). The plot was a matrix of evenly spaced, alternating sagebrush (Artemisia tridentata ssp. vaseyana) and Agrropyron desertor transplanted into the plot in 1978. Individual plants were spaced $50 \mathrm{~cm}$ apart. The sagebrush plants provided a uniform competitive background for the grasses. The soils consist of rocky Mollisols covering alluvial deposits (Caldwell et al. 1981). The average annual precipitation is $468 \mathrm{~mm}$, much of which occurs as snow during the winter months. More detailed climate and site information can be found in Caldwell et al. (1981). 


\section{Defoliations}

Tussocks of A. desertorum were defoliated in three different spatial patterns. The tussocks were carefully hand clipped in order to closely replicate each defoliation pattern on 7 tussocks in 1985 and 6 tussocks in 1986. These defoliation patterns represented extremes of different patterns that could result from actual herbivores. In the uniform defoliation pattern, all tillers of the tussock were clipped at the same height. For the upper leaf blade removal treatment, -upper, the uppermost $2-3$ green leaf blades were removed from each tiller on the plant; for the lower leaf blade removal treatment, -lower, the lowest 2-3 green leaf blades were removed. The leaf sheaths were left intact in the -upper and -lower defoliation patterns. There were 4-5 green leaf blades present on each tiller at the time of defoliation. Immediately prior to defoliation, foliage surface area distribution was measured as described below. This information was used to ensure that, for each clipping pattern, approximately sixty percent of the total green foliage surface area was removed (Table 1). The foliage clipped off was dried for $48 \mathrm{~h}$ at $70 \mathrm{C}$ and weighed. The weight of the foliage clipped off was later added to the peak standing crop to estimate total-season aboveground production. Control plants were not defoliated. 
Table 1. Percentage of total green foliage area removed from tussocks by the defoliation treatments. The numbers in parentheses are the standard error of the mean. Different letters would indicate significant differences $(P<.05)$ among means ( $n=6$ or 7 ) within each defoliation date.

\begin{tabular}{llll}
\hline $\begin{array}{c}\text { Defoliation } \\
\text { Pattern }\end{array}$ & $\begin{array}{l}1985 \text { Early } \\
\text { Defoliation }\end{array}$ & $\begin{array}{l}1986 \text { Early } \\
\text { Defoliation }\end{array}$ & $\begin{array}{l}1985 \text { Late } \\
\text { Defoliation }\end{array}$ \\
\hline Uniform & $61.6(2.1)$ a & $60.3(2.6)$ a & $67.6(1.5) \mathrm{a}$ \\
-Upper & $58.8(1.0)$ a & $56.3(2.4)$ a & $64.6(1.4) \mathrm{a}$ \\
-Lower & $59.1(1.2)$ a & $55.1(2.4)$ a & $63.2(1.5) \mathrm{a}$ \\
\hline
\end{tabular}

clipping experiments were carried out prior to the elevation of apical meristems in 1985 and 1986 (mid-May, Table 2). Those defoliations left all apical meristems

Table 2. Experimental details and timetable.

\begin{tabular}{|c|c|c|c|c|c|c|}
\hline Year & $\begin{array}{l}\text { Defollation } \\
\text { Date }\end{array}$ & $\begin{array}{l}\text { Ap1cal Meristem } \\
\text { Position }\end{array}$ & $\begin{array}{l}\text { No. Green } \\
\text { B1ades/Culm }\end{array}$ & $\begin{array}{l}\text { No. Plants/ } \\
\text { Treatment }\end{array}$ & $\begin{array}{l}\text { Follage Area } \\
\text { Preclipping }\end{array}$ & $\begin{array}{c}\text { Measurement Dates } \\
\text { Postclipping }\end{array}$ \\
\hline 1985 & May $17-19$ & Near Ground & $4-5$ & 7 & May 1,16 & May 19, June 4, 20 \\
\hline 1985 & May $28-29$ & Elevated & $5-6$ & 7 & May 2,27 & May 30 , June 13 , July 6 \\
\hline 1986 & May $10-14$ & Near Ground & $4-5$ & 6 & May 10 & May 15,29 , June 13 \\
\hline
\end{tabular}

intact. An identical clipping experiment was done after apical meristem elevation in late May of 1985 (Table 2). In this experiment, the apical meristems of the uniform defoliation plants were removed, whereas they were not removed in the -upper and-lower plants. About sixty five percent of the total green foliage area was removed by each 
defoliation treatment in this experiment (Table 1).

\section{Foliage surface area}

measurement

Changes in the green foliage area of the tussocks were estimated by measuring changes in the surface area of representative tillers within each tussock. Immediately following snowmelt, ten randomly chosen tillers were marked by wrapping color-coded wires around their bases. Five of the tillers were marked in a ring near the center of the tussock and five in a ring near the periphery. Green foliage area on the marked tillers was estimated by measuring the length and maximum width of every leaf blade and the length and diameter of all green sheaths on those tillers. The surface area of sheaths was calculated as half of a cylinder. The surface area of leaf blades (one side) was estimated from linear regression models that related the length and maximum width of each leaf blade to the actual surface area for clipped blades and intact blades which were expanded or rolled (see Appendix). Changes in the surface area of the entire tussock were estimated by counting the number of tillers in each tussock and assuming that the ten marked tillers were representative of the whole plant. The number of tillers per tussock ranged from 150 to 350 . During the last two sampling dates (Table 1), the marked tillers were divided into vegetative and reproductive tillers because the foliage area dynamics of the two tiller types were different. 
types were different.

Specific growth rates (SGR ; Thornley 1976), based upon changes in foliage area relative to the initial foliage area, were calculated for the three-week period immediately preceding clipping in 1985 and two sequential 14-d periods after clipping in 1985 and 1986. The SGR was calculated as $S G R=\left(S A_{t 2}-S A_{t 1}\right) /\left(S A_{t 1}\right)(t 2-t 1)$

where $S A$ was the green foliage area at times $t 1$ and $t 2$. Tussock growth rates were assumed to be linear during each of these periods of growth. Reproductive portions of the tussocks were not included in these measurements. The SGR is a net change which includes the processes of plant material production and loss through senescence. Production and senescence were estimated by examining changes in the green surface area of each of the individual foliage elements within the marked tillers. All increases in green surface area of foliage elements were summed to estimate the production of new plant material and all decreases were summed to estimate senescence. In this chapter, the terms SGR, growth and regrowth are used to denote net changes in green foliage area, while production refers to the positive increments and senescence to the negative increments associated with the net changes.

Aboveground biomass production

The peak standing biomass was measured for all tussocks by harvesting all aboveground plant parts on July 16 and 17 
(70 C for $48 \mathrm{~h}$ ) and weighed. The ratio of peak standing biomass to preclipping foliage area (relative biomass production) was used in the analysis to account for initial differences in tussock size.

Means of the proportion of foliage removed, growth rates and relative biomass production were compared with analysis of variance and linear contrasts among the four treatments within each year. References to significant differences indicate values of $\mathrm{P}<.05$.

Results

Defoliation before apical meristem elevation

When tussocks were clipped prior to apical meristem elevation (mid-May) the spatial pattern of foliage removal had a significant effect on plant regrowth. Prior to defoliation, plants from all treatments in the 1985 experiment exhibited the same SGR (Table 3). All

Table 3. Total foliage area specific growth rates ${ }^{*}$ during a three-week period prior to clipping in the $1985 \mathrm{mid}-\mathrm{May}$ clipping experiment. The numbers in parentheses are the standard error of the mean $(n=7)$. Different letters indicate significant differences $(P<.05)$ among the means.

Treatment

\begin{tabular}{cccccc} 
Control & Uniform & -Upper & -Lower \\
\hline $0438(.0024)$ a & $.0397(.0024)$ a & $.0372(.0024)$ a & $.0429(.0018)$ a \\
\hline
\end{tabular}

$* \mathrm{~cm}^{2} \mathrm{~cm}^{-2} \mathrm{~d}^{-1}$ 
defoliation patterns resulted in increased growth rates during the first two weeks of regrowth in both years (Fig. 1). The increase in SGR was significantly greater in the -lower plants than in plants from the other two defoliation patterns. During the second two weeks following defoliation the SGR of the uniform and -upper plants were equivalent to the control plants but the -lower plants maintained a higher SGR. In 1985 the SGR of most of the plants were near zero during the second regrowth period, indicating that production of foliage area balanced senescence. The SGR measured in 1986 were higher than the 1985 SGR perhaps in part because the 1986 experiment was started one week earlier in the growing season (Table 2).

The differences in foliage area regrowth among treatments were the result of differences in leaf blades rather than of leaf sheaths (Fig. 2). Leaf blade SGR showed the same results as those described above for the total foliage area SGR (Fig 2a). During the first two weeks of regrowth, there was an increase in blade SGR of all clipped plants and this increase was significantly greater in the -lower plants than the other clipped plants.

Much of the increase in sheath area of $\underline{A}$. deserertor $\underline{\text { de }}$ accompanies the rapid elongation of tiller internodes and consequently corresponds closely with plant height. Sheath area growth rates were not significantly affected by defoliation or the pattern of defoliation (Fig. 2b). The similar sheath area dynamics indicate that the relative 


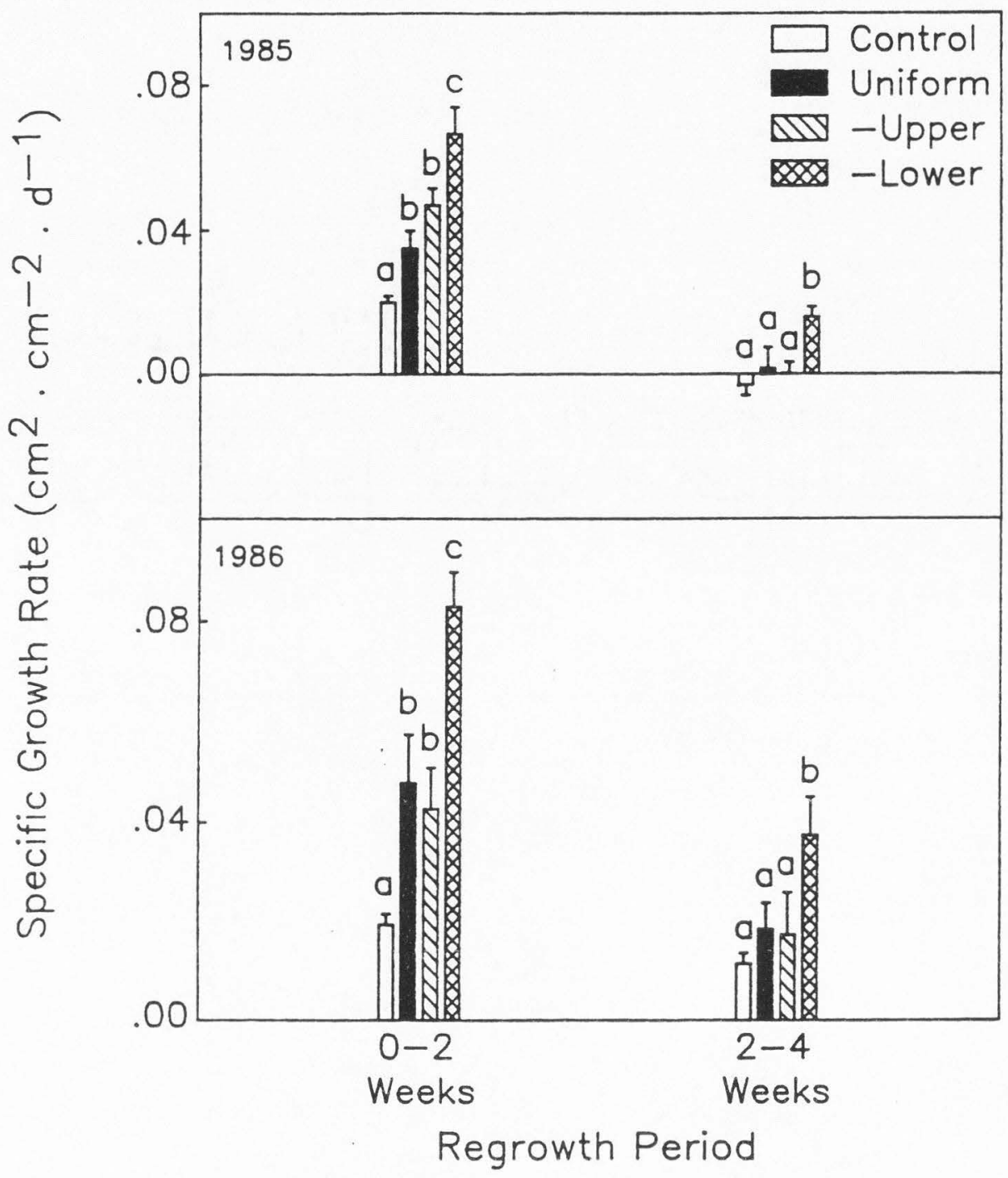

Fig. 1. Specific growth rates of green foliage area for two sequential regrowth periods following mid-May clipping. Each value is the mean of 6 (1986) or 7 (1985) tussocks, shown with the standard error. Letters indicate significant differences $(P<.05)$ within one regrowth period of a single year. 

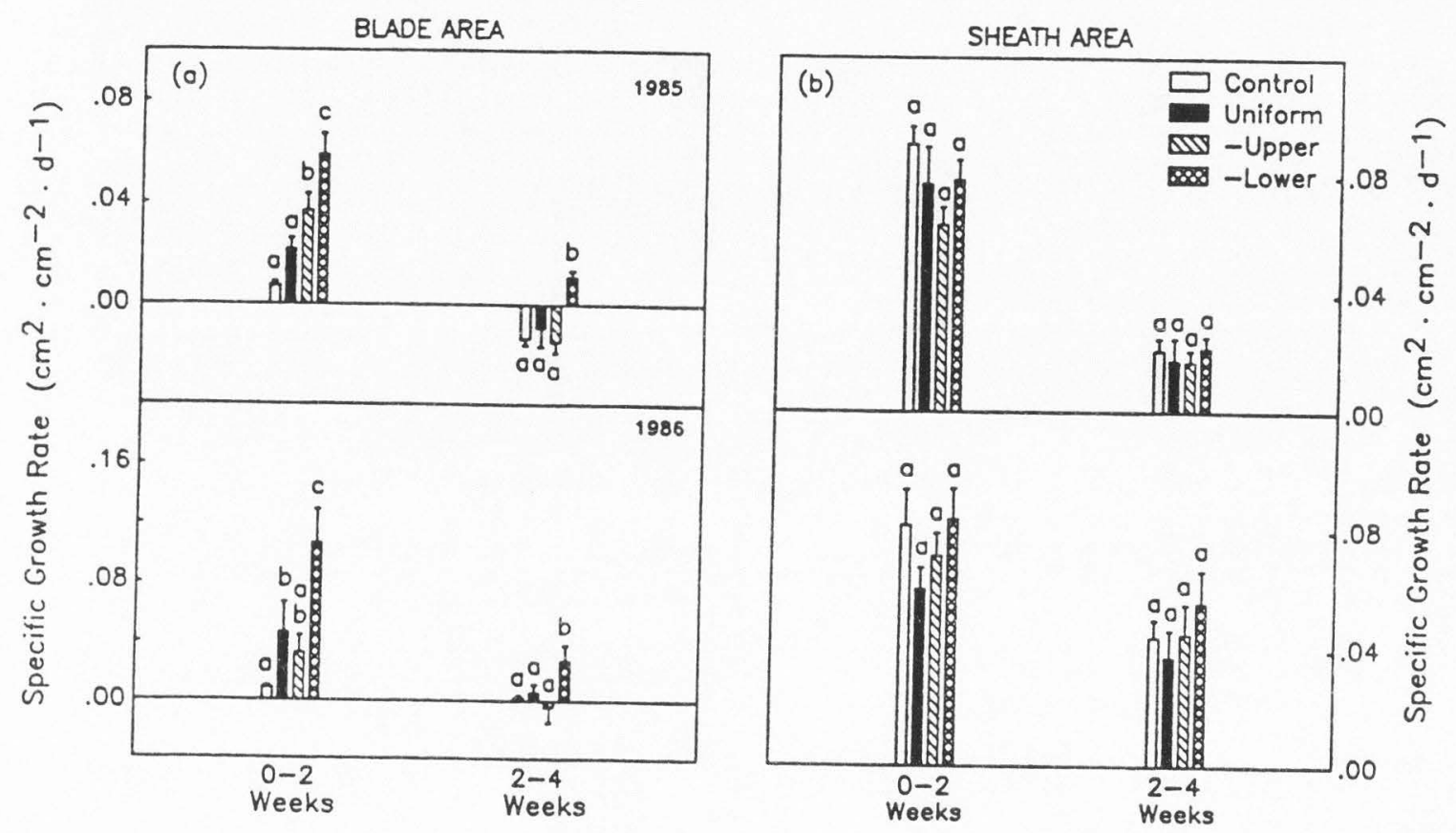

Regrowth Period

Fig. 2. Specific growth rates of (a) leaf blade area and (b) leaf sheath area for two sequential regrowth periods following mid-May clipping. Each value is the mean of 6 (1986) or 7 (1985) tussocks, shown with the standard error. Letters indicate significant differences $(P<.05)$ within one regrowth period of a single year. 
increase in tussock height during the first four weeks of regrowth was the same among the treatments.

The increased growth rates of all clipped plants during the first two weeks of regrowth was a result of greater production of new plant material (Fig. 3). There were no consistent differences among senescence rates during this period in both years. Foliage production during the second regrowth period was not significantly different among the clipping patterns in 1985. The higher regrowth rate of the -lower plants in the second regrowth period of 1985 was due to reduced senescence. The leaf blades which would have been dying at this time were removed by the -lower defoliation. In 1986, however, the higher regrowth rates of the -lower plants during the second regrowth period resulted from greater production rather than reduced senescence. The differences between the 1985 and 1986 results may have been due in part to the initiation of the experiments one week earlier in 1986.

Defoliation pattern had a significant effect upon aboveground biomass measured near the end of the growing season (peak standing crop). Peak standing crop was reduced by nearly fifty percent in the uniform and -upper plants relative to the control plants (Fig. 4a). Removal of lower leaf blades, however, produced no discernable change in peak standing crop. Total-season aboveground biomass production was estimated by adding the weight of the plant material clipped off to the peak standing crop. This is still an 

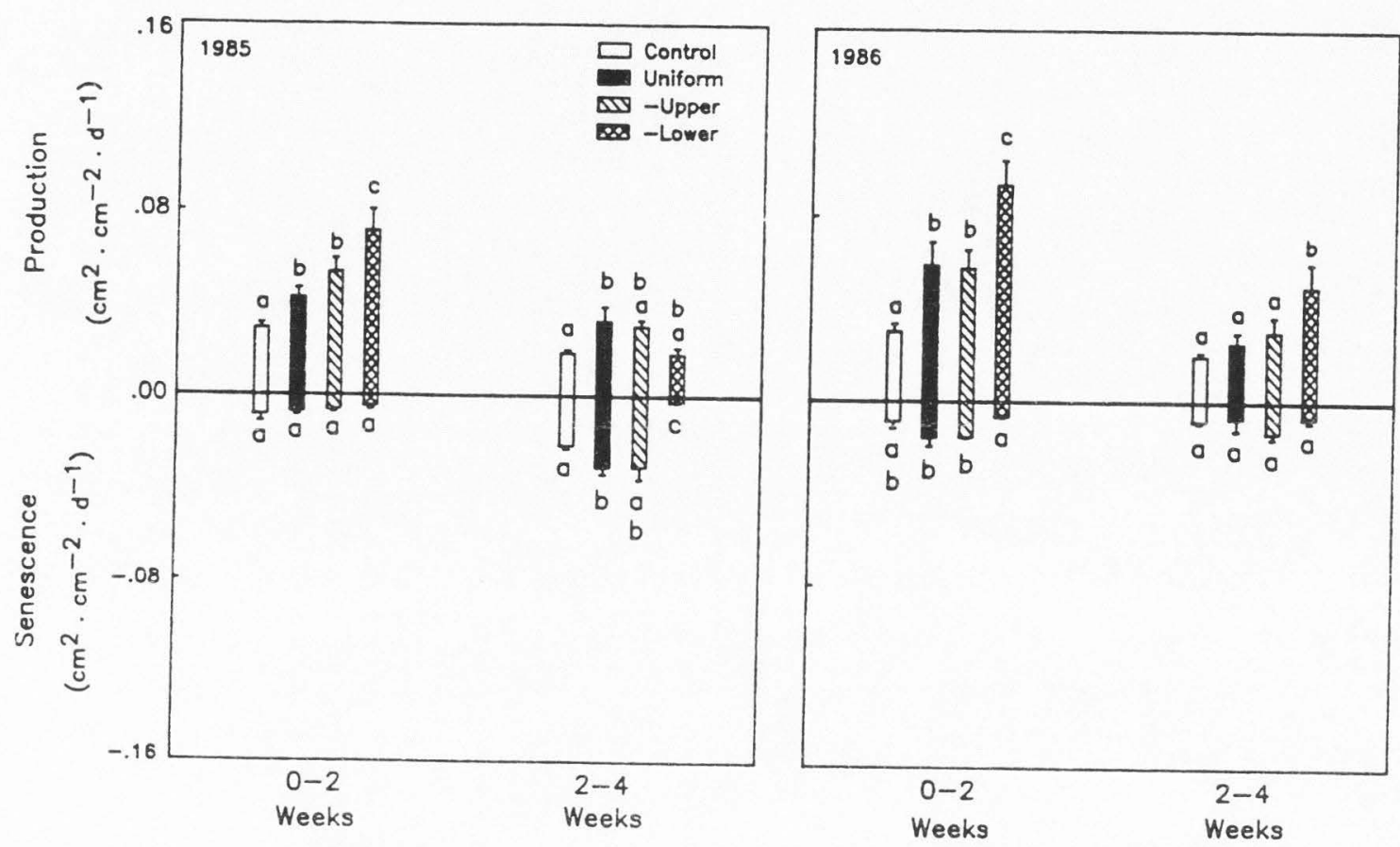

Regrowth Period

Fig. 3. Rates of production and senescence of green mid-May clipping. Each value is the meath periods following (1985) tussocks, shown with is the mean of 6 (1986) or 7 indicate significant wiff the standard error. Letters regrowth period of a single year $(P<.05)$ within one 


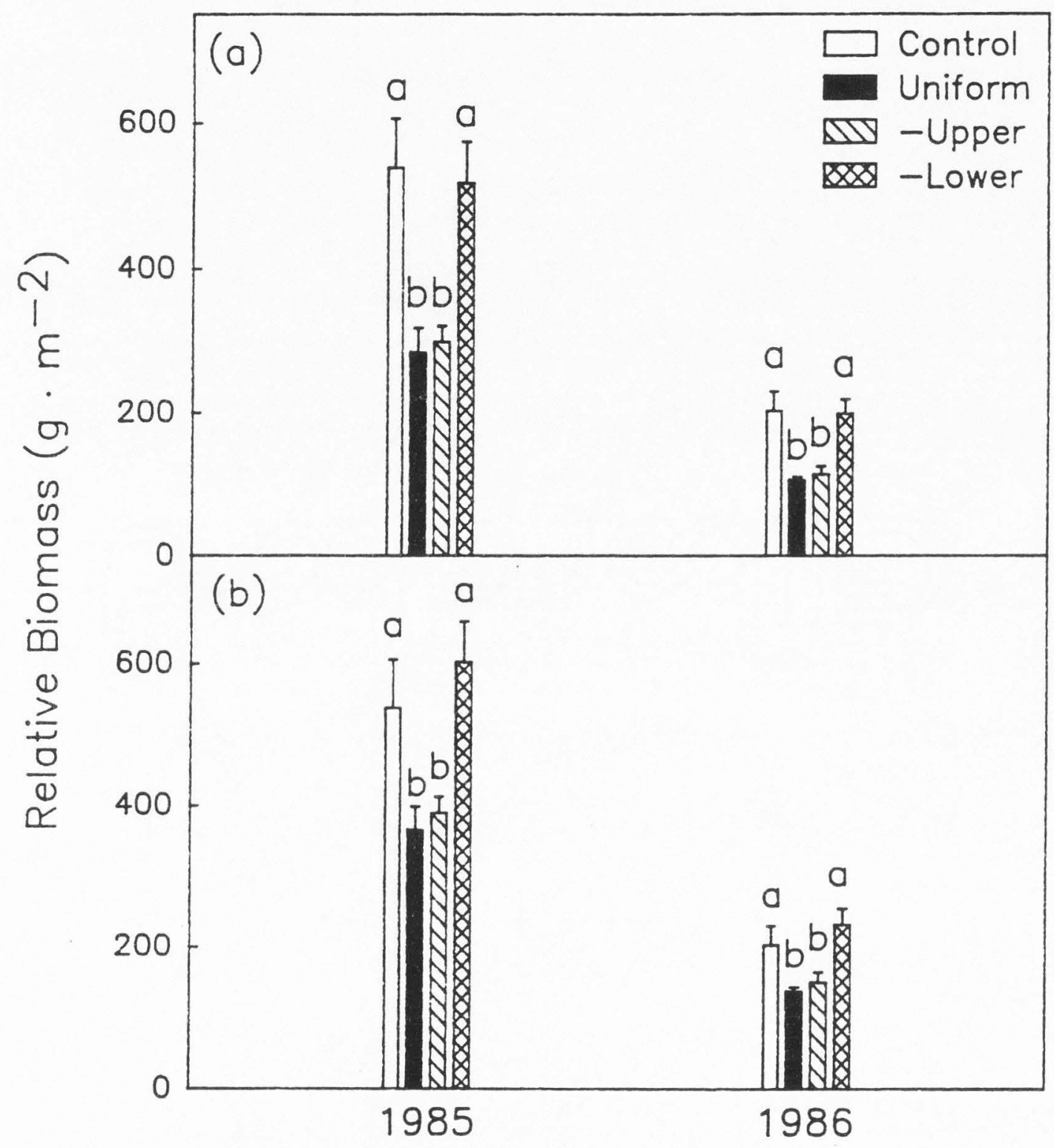

Fig. 4. (a) Peak standing crop and (b) total-season aboveground biomass production relative to the green foliage area of the tussock prior to clipping. Tussocks were clipped in mid-May. Each value is the mean of 6 (1986) or 7 (1985) tussocks, shown with the standard error. Letters indicate significant differences $(P<.05)$ within each year. 
underestimate of actual total-season aboveground production because of the senescence and loss of leaf blades prior to the peak standing crop harvest. Total-season aboveground production was reduced only by about thirty percent for the uniform and -upper plants, even though sixty percent of their foliage had been removed in mid-May (Fig. 4b). This corresponds to partial compensation as defined by Belsky (1986). Total-season aboveground production by -lower plants was not affected significantly by the sixty percent foliage removal (i.e. exact compensation, Belsky 1986). Aboveground production by the -lower plants was not greater than the controls (Fig. 4b) despite the equal peak standing crop of the -lower and control plants (Fig. 4 a) because the amount of biomass clipped off of -lower plants was small relative to both the peak standing crop (15\%) and the variability present in the data.

The relative effects of defoliation patterns on biomass production were consistent for both years, despite large differences between the years in the absolute amount of production (Fig. 4). Season-long production was much greater in 1985 than 1986 (Fig. 4), even though the SGR of tussocks following clipping was similar in those years (Fig. 1). Therefore, the differences between 1985 and 1986 in season-long production must have arisen from differences in the amount of production prior to clipping. These differences in early-season production were probably not due to differences in soil moisture. There were no appreciable 
differences between these two years in soil water potentials (at $20,40,60$, and $80 \mathrm{~cm}$ depths) during the spring in a similar plot located within $50 \mathrm{~m}$ of my experimental plot (Busso, unpublished data). However, springtime air temperatures were considerably different in the two years. For example, the daytime maximum air temperatures measured at canopy height during the first week of May ranged from 18 to $25 \mathrm{C}$ in 1985 and 6 to $15 \mathrm{C}$ in 1986. The greater amount of early-season foliage production in 1985 than in 1986 was probably due to the higher daytime air temperatures during the spring of 1985.

\section{Defoliation after apical}

\section{meristem elevation}

When defoliation took place after culm elongation (late May), the uniform defoliation removed all apical meristems, whereas the leaf blade removal treatments (-upper and -lower) left them intact. The results from these later defoliations were substantially different from the mid-May defoliations.

Plants of the leaf blade removal patterns exhibited increased growth rates relative to controls in the first two weeks following defoliation, but the uniform defoliation plants showed no such increases during that period (Fig. 5a). During the second two weeks of regrowth, plants of the -upper and -lower patterns maintained SGR near zero, whereas control and uniform defoliation plants showed a net loss of green foliage area (Fig. 5a). As in the early defoliation 


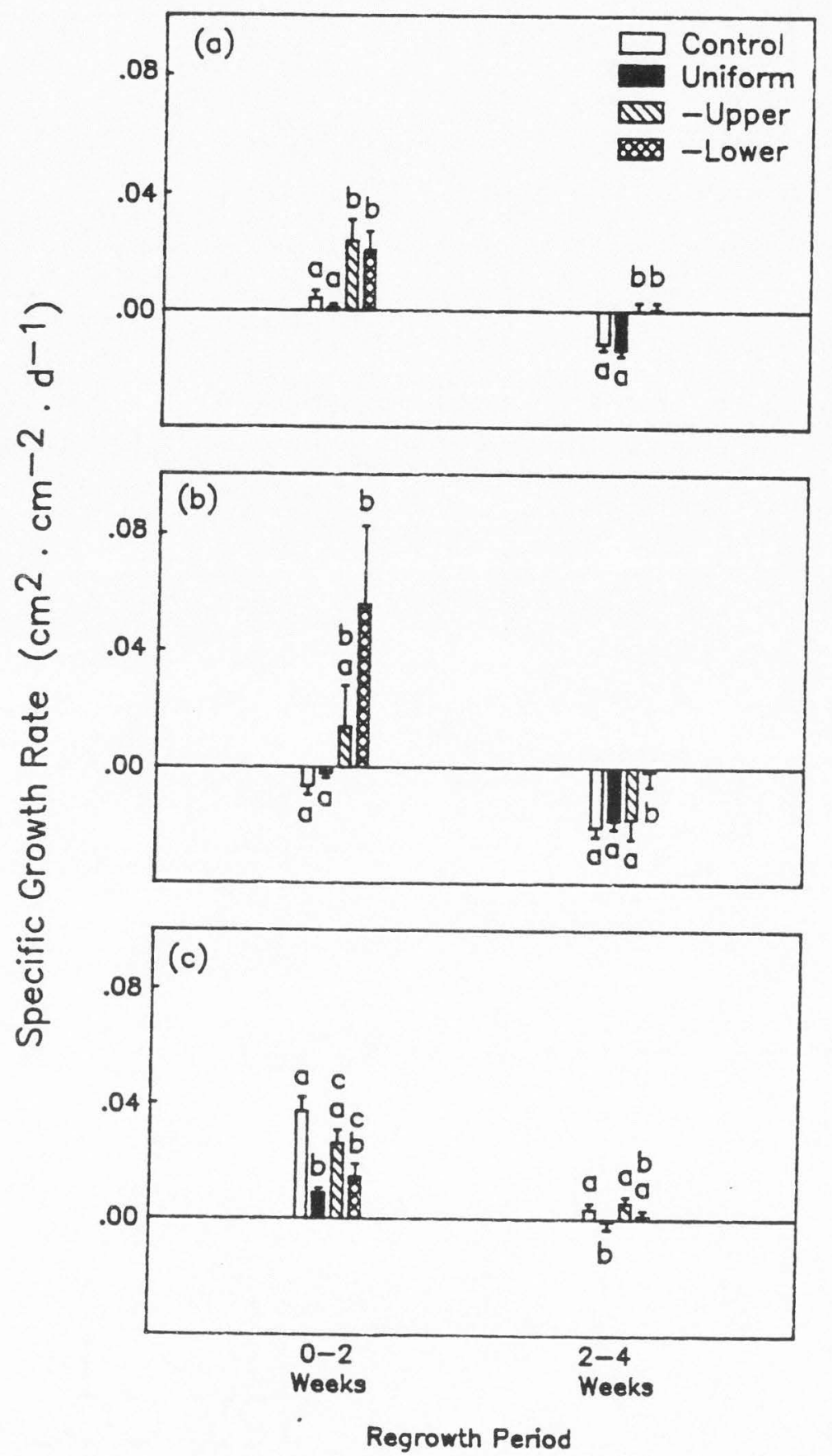

Fig. 5. Specific growth rates of (a) green foliage area, (b) leaf blade area and (c) leaf sheath area following lateMay clipping in 1985. Each value is the mean of 7 tussocks shown with the standard error. Letters indicate significant differences $(P<.05)$ within each regrowth period. 
experiment, much of the compensatory regrowth response occurred in leaf blades rather than leaf sheaths (Figs. $5 b, c)$. However, the sheath SGR of the uniform and -lower plants were reduced in this experiment. For the uniform defoliation plants, this was due to the cessation of internode elongation of the original tillers following apical meristem removal.

Uniform-defoliation plants did not produce new foliage during the first 14 d after late-May clipping (Fig. 6). Regrowth on these plants eventually originated from previously quiescent axillary buds because the apical meristems had been removed. Visible production of foliage from the axillary buds (secondary tillers) did not occur until the third week following defoliation. In the third and fourth weeks of regrowth, there was an increase in both the production and senescence of the uniform-defoliation plants caused by secondary tiller initiation and rapid senescence of the original tillers (Fig. 6). The secondary tillers on the uniform-defoliation plants remained green and maintained production long after the primary tillers of -lower, -upper, and control plants had reached summer dormancy. There was no secondary tiller production on -upper, -lower, and control tussocks.

Late-May defoliation reduced the peak standing crop of all defoliated plants, regardless of defoliation pattern (Fig. 7a). The uniform defoliation pattern caused the most severe reduction in peak standing crop. Increased 


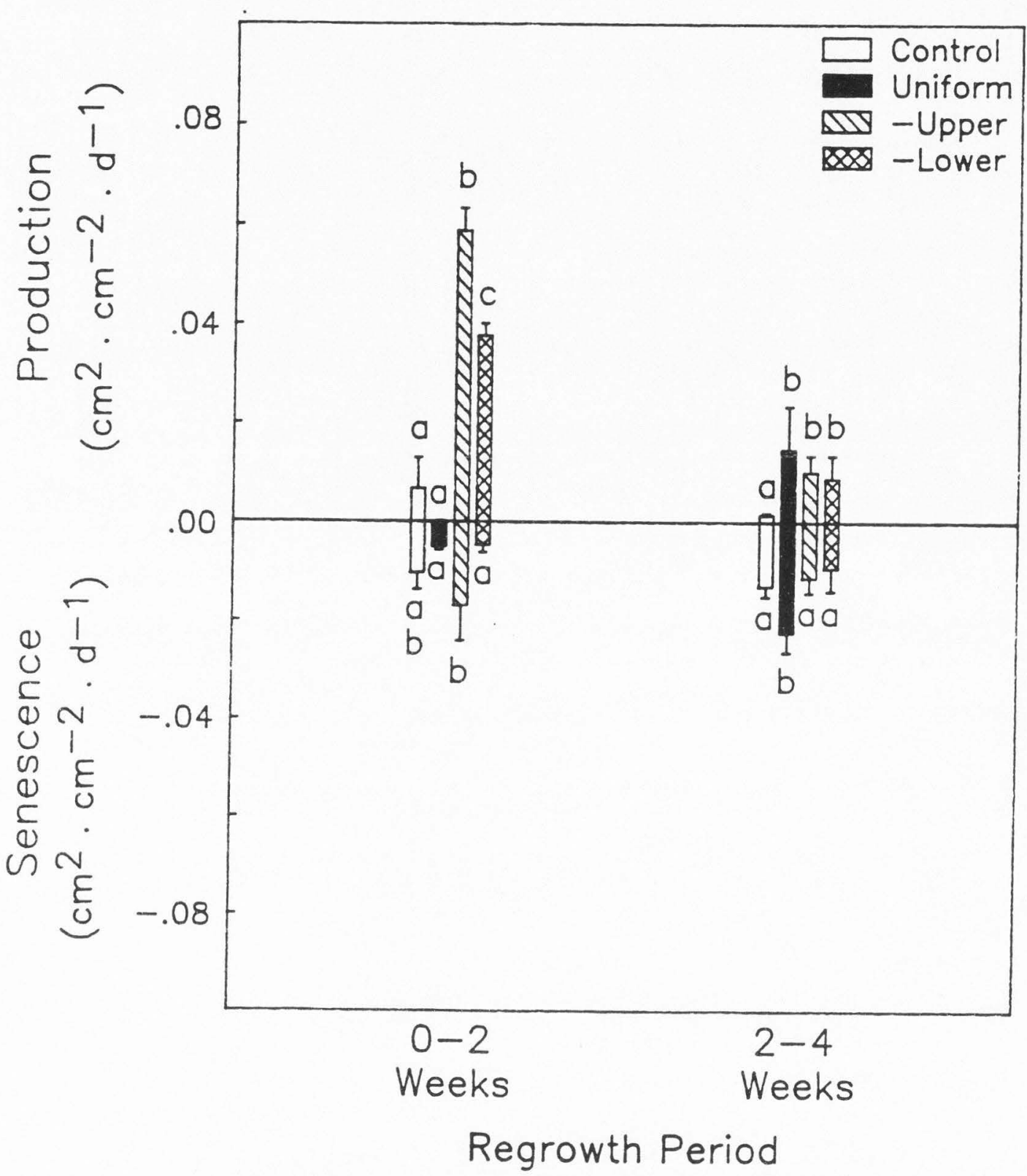

Fig. 6. Production and senescence rates of green foliage area following late-May clipping in 1985. Each value is the mean of 7 tussocks shown with the standard error. Letters indicate significant differences $(P<.05)$ within each
regrowth period. 


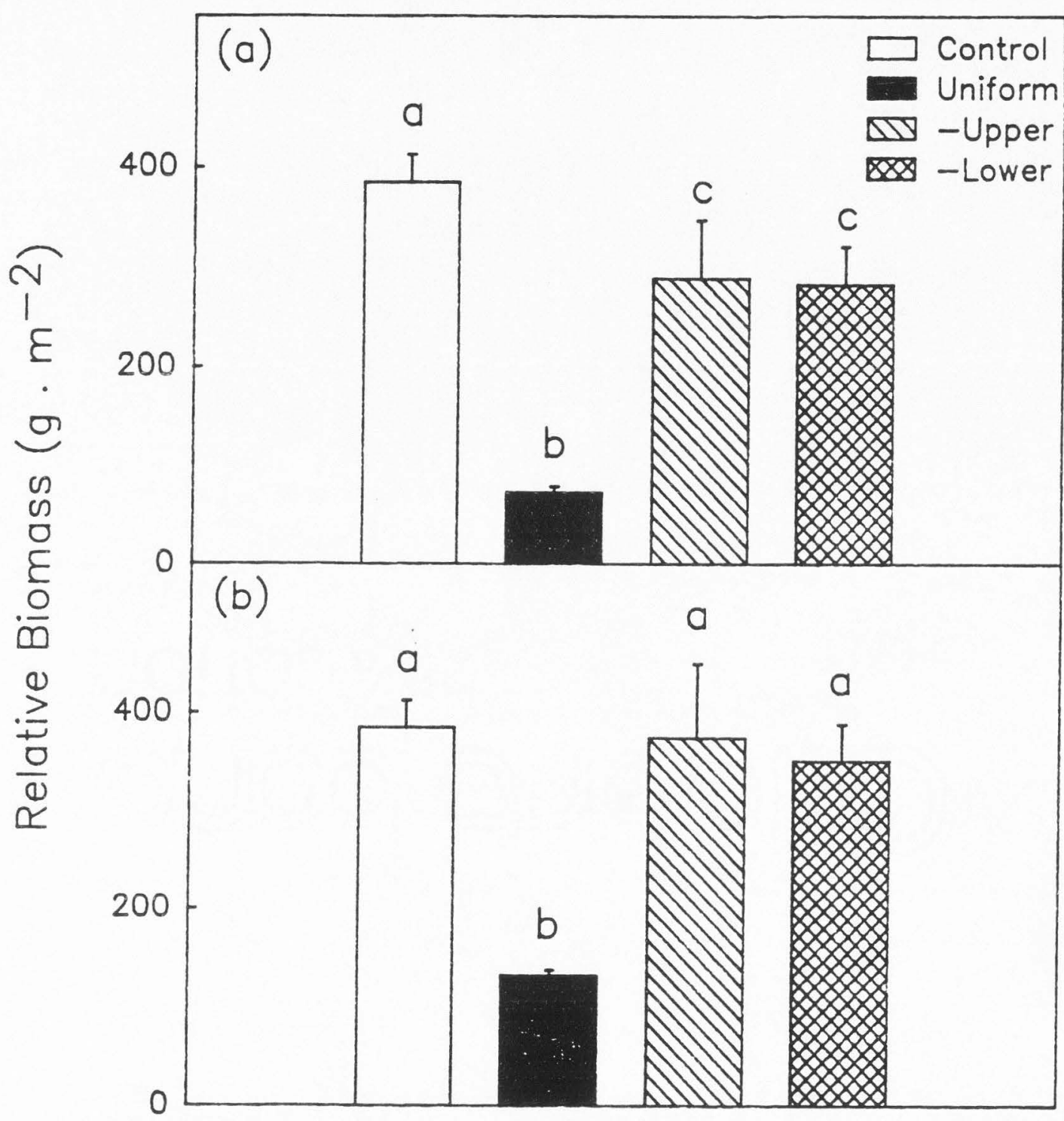

Fig. 7. (a) Peak standing crop and (b) total-season aboveground biomass production relative to the green foliage area of the tussock prior to clipping. Tussocks were clipped in late May of 1985. Each value is the mean of 7 tussocks shown with the standard error. Letters indicate significant differences $(P<.05)$ among the means. 
aboveground growth rates of plants which had upper or lower leaf blades removed (Fig. 5) resulted in exact compensation of total-season aboveground biomass production (Fig. $7 \mathrm{~b}$ ). The uniform defoliation plants exhibited a 66 percent reduction in total-season aboveground production relative to control plants. This is remarkably close to the 67 percent defoliation those plants underwent (Table 1), indicating that the relative production of the uniform plants over the remaindex of the growing season following defoliation was similar to the control plants (i.e. no compensation, Belsky 1986)

\section{Discussion}

The degree to which plants can compensate for tissue removal by herbivores can vary greatly depending upon the species and circumstances (Belsky 1986, McNaughton 1986). The intensity, timing and frequency of defoliation can affect plant regrowth responses (Ludlow and Charles-Edwards 1980, Dyer et al. 1982, McNaughton et al. 1983). Except for a few studies which evaluated the removal of different-aged foliage (Stickler and Pauli 1961, Brown et al. 1966, Dirzo 1984, Mendoza et al. 1987), little attention has been paid to the importance of the spatial pattern of defoliation within a plant canopy. In this study, I have shown that the spatial pattern of defoliation within the canopy of a tussock grass plant can have important effects on aboveground regrowth. These effects were consistent for two years with very different amounts of plant production (Fig. 
4). Tussocks which had older leaves (lower in the canopy) removed during rapid growth in mid-May were able to fully compensate for this defoliation by the time of peak standing crop. The season-long aboveground biomass production of those tussocks was the same as tussocks which were not defoliated (Fig. 4). Tussocks from which younger foliage (higher in the canopy) was removed were only able to partially compensate for this defoliation. These results qualitatively correlate with the results of previous work on the removal of different-aged leaves (e.g. Sackston 1959, Stickler and Pauli 1961, Kulman 1965, Mendoza et al. 1987).

Increases in growth can be the result of reduced rates of tissue senescence (e.g., Nowak and Caldwell 1984) and/or increased production of new foliage. Increased longevity of remaining foliage following defoliation has been suggested as a mechanism for compensatory growth (McNaughton 1983). However, in my study there was no evidence for delayed senescence of remaining tissues on any of the defoliated plants following mid-May defoliation. The apparent reduction in foliage senescence of the -lower tussocks was due to the removal (by the clipping treatment) of leaves which were dying on tussocks of the other treatments rather than an increase in tissue longevity.

The initial differences in regrowth after mid-May defoliation were clearly a result of differences in production of new leaf blade area rather than sheath area (Figs. 2 and 3). Because changes in sheath area correspond 
closely with internode elongation and plant height, I would caution against the use of plant height as a sole measure of response to defoliation in these grasses. The differences in blade area production following mid-May clipping were due to changes in the size of leaf blades rather than the number of blades produced. Tussocks of all treatments produced an average of three leaves following defoliation in mid-May. Differences in the rate of new blade area production resulted from differences in the activity of intercalary meristematic regions.

The rapid growth of leaf sheaths, which accompanies internode elongation, has been shown to be insensitive to leaf blade removal (Cook and stoddart 1953, Hyder 1972). In many grasses, the initiation of internode elongation is primarily controlled by photoperiod (Hyder 1972). In this study, sheath area production was unaffected by any of the clipping treatments applied in mid-May, despite large differences in the influence of the treatments on tussock carbon gain (chapter III). Thus, carbon availability was probably not the principal constraint to sheath area production.

The timing of defoliation, particularly in relation to abiotic factors and the phenological development of the plant, can have important implications for plant response to defoliation (Cook et al. 1958, Harper 1977, Binnie et al. 1980, Olson and Richards 1988). The competitive balance among plant species can also be affected by the timing of 
defoliation (Bentley and whittaker 1979, Crawley 1983, Caldwell et al. 1987). The relative effects of different spatial patterns of defoliation on plant meristems may also change with the timing of defoliation. In caespitose grasses, such as $\underline{\text { A. }}$ desertorum, the susceptibility of active meristematic tissue to herbivory varies with the time of the season. In the early spring, until mid-May, the apical meristems remain near the soil surface and escape removal. In late May, during culm elongation, the apical meristems are elevated and become increasingly susceptible to removal by herbivores. Growth following defoliation is affected by the number, type and activity of meristems remaining on the plant (Briske 1986). With the removal of apical meristems in A. desertorum, production of new leaves must come from the activation of quiescent basal meristems on each original tiller. This is a relatively slow process compared to continued foliage production from active intercalary meristems (Richards and Caldwell 1985, Briske 1986).

The importance of considering how the spatial pattern of defoliation affects meristematic limitations to growth is evident in the results from the late-May defoliation experiment. Uniform defoliation in late May removed all apical and intercalary meristems and resulted in no compensation in aboveground biomass production relative to control plants (Fig. 7). In contrast, the removal of either upper or lower leaf blades left active intercalary meristems intact and resulted in full compensation. The equal 
regrowth of tussocks from which upper or lower leaf blades were removed was unexpected because those two treatments had different effects on canopy microclimate and foliage age structure (Chapter IV). Thus, in the late-May clipping experiment, the impact of the spatial pattern of defoliation on plant meristems had greater consequences for tussock regrowth than changes in foliage age structure or canopy microclimate.

The timing of defoliation can affect the relative impact of different defoliation patterns even when plant meristems are not removed. Mendoza et al. (1987) found that the relative effects of different defoliation patterns on an understory palm depended upon the developmental state of the plant. The effects of their defoliation patterns on meristems did not change with the timing of defoliation. In my study, apical meristems were left intact in both leafblade removal patterns in the mid-and late-May defoliations. Although the compensatory growth response was different in -lower and -upper plants after clipping in midMay (Fig. 1), it was equal in those two treatments following late-May defoliation (Fig. 5). This could have been due to smaller differences in photosynthetic characteristics of different-aged foliage in late May. The difference in the relative responses of these two treatments between mid- and late-May defoliation could also have been a result of changes in the developmental state of the intercalary meristems. 
Knowledge of the mechanisms through which different defoliation patterns affect regrowth is crucial in order to predict the effects of various herbivore defoliation patterns. Carbon is probably the principal constraint to leaf blade production in the mid-May experiment. Water and mineral nutrients are relatively abundant at this time of year. Fertilization of $\underline{A}$. desertorum with nitrogen and phosphorus in the spring of wet year did not produce measurable increases in tussock growth (Mazurski, unpublished data). Meristematic limitations to growth are also small due to the presence of active apical meristems (Richards and Caldwell 1985, Briske 1986). The primary source of carbon for $\underline{A}$. desertorum at this time is current photosynthate because pools of soluble carbohydrate available for regrowth are relatively small (Richards and Caldwell 1985). Thus, the observed differences in regrowth following mid-May clipping were probably due to effects of different defoliation patterns on tussock photosynthesis and carbon balance. The consequences of these spatial patterns of defoliation for tussock gas exchange, foliage age structure and canopy microclimate are considered in Chapters III and IV.

The spatial pattern of foliage removal by herbivores from within a tussock grass can clearly have important consequences for tussock regrowth. Additionally, the timing of herbivore activity can have a large influence on the relative severity of different defoliation patterns. 
Experimental evaluations of plant response to defoliation should consider characteristics of the activity of actual herbivores. The results of these experiments indicate that plant response to defoliation should be assessed in the context of relevant patterns of foliage and meristem removal. 
CHAPTER III

THE EFFECTS OF THE SPATIAL PATTERN OF DEFOLIATION

ON REGROWTH OF A TUSSOCK GRASS:

II. CANOPY GAS EXCHANGE

Introduction

The stimulation of plant growth following partial defoliation often results in at least partial growth compensation for the tissue removal (McNaughton 1979a, 1983, Caldwell et al. 1981, Dyer et al. 1982). Increases in carbon dioxide $\left(\mathrm{CO}_{2}\right)$ assimilation rates (Gifford and Marshall 1973, Heichel and Turner 1983, Woledge 1977), stomatal conductance (Detling and Painter 1983, Wallace et al. 1984), and soluble protein concentrations (Nowak and Caldwell 1984) of regrowing foliage have also been observed. However, attempts to directly relate such physiological phenomena at the single-leaf level to wholeplant responses has met with limited success (Gifford and Jenkins 1982, Detling and Painter 1983, Nowak and Caldwell 1984, Bunce 1986).

Research on grass swards has demonstrated that a number of factors including canopy structure, light interception, and foliage photosynthetic characteristics are crucial to the carbon balance and growth of the sward (Ludlow and Charles-Edwards 1980, Sheehy 1977, Sugiyama et al. 1985, Woledge and Leafe 1976). Recent models of grass sward growth have been successful in understanding carbon balance and growth based upon data of canopy structure and foliage 
physiological characteristics (Coughenour 1984, Coughenour et al. 1984, Johnson and Parsons 1985a,b, Johnson and Thornley 1985). Changes in canopy structure, light interception, and foliage age structure of a plant are reflected in the photosynthetic characteristics of the entire canopy (Monsi et al. 1973). Hence, plant growth responses following defoliation should be closely associated with whole-canopy photosynthesis and may not necessarily be well represented by single-leaf photosynthesis.

In chapter II, I showed that the spatial pattern of defoliation within a tussock grass, Agropyyron dese (Fisch. ex Link) Schult. affected the degree of compensatory growth response. During the spring, these dense tussocks of A. deserertorum have considerable amounts of shaded foliage (Caldwell et al. 1983a). The contribution of some of this shaded foliage to tussock $\mathrm{CO}_{2}$ uptake may be Iimited by the low irradiance levels (e.g. Koerner 1982). Also, there are considerable differences in the photosynthetic characteristics of different-aged foliage within the tussocks in the spring (Nowak and Caldwell 1984). It is likely that the spatial pattern of defoliation influences light microclimate and foliage age structure of tussocks, and consequently alters the net daily carbon gain of these plants.

In this study, I evaluated the effects of the spatial pattern of defoliation on canopy $\mathrm{CO}_{2}$ exchange and its relationship to tussock regrowth. The gas exchange of 
tussock canopies was measured before and after they were defoliated in spatial patterns which represented extremes of different patterns that could be inflicted by natural herbivores. I also examined the ratio of daytime $\mathrm{CO}_{2}$ uptake to water vapor loss (WUE) to evaluate the hypothesis of Caldwell et al. (1983a) that certain patterns of defoliation might result in increased WUE.

Methods

\section{$\underline{\text { study area }}$}

The experiments were conducted in a field plot at the Green Canyon Ecology center in northern Utah (42 N latitude, $1460 \mathrm{~m}$ above sea level). The field plot was a matrix of evenly spaced (50 cm), alternating sagebrush

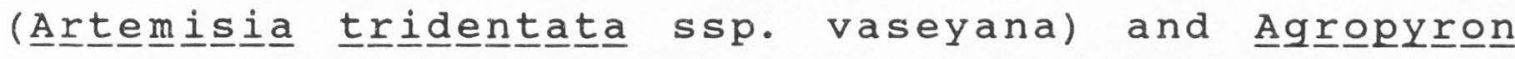

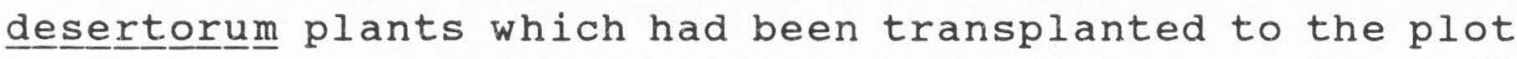
eight years prior to these experiments. The sagebrush plants provided a uniform competitive background for the grasses. More detailed climate and site information can be found in Caldwell et al. (1981).

\section{Defoliation treatments}

Twelve A. desertorum tussocks were chosen within the field plot and each tussock was assigned to one of three replicate sets, each containing four plants. Each of the four plants within a set was assigned to a different defoliation treatment. The defoliation of the 3 replicate 
sets was staggered over a 5 -d period. This allowed the simultaneous measurement of the gas exchange of all four plants within a set immediately before and after defoliation with the four gas exchange chambers.

Three of the four plants in each set were hand clipped between May 12 and May 16, 1986. The fourth plant remained intact as a control. The tussocks were still in a culmless state, with the apical meristems near the soil surface, at the time of clipping. All of the tillers on the tussock were clipped at the same height above the ground in the uniform-defoliation treatment. The other two clipping treatments removed either the lowest 2 to 3 green leaf blades on each tiller, -lower, or removed the uppermost 2 to 3 green leaf blades from each tiller, -upper. There were 4 to 5 green leaf blades present on each tiller prior to defoliation. In all cases, approximately sixty percent of the green foliage area of the plant was removed (Chapter II, Table 1). The apical meristems were left intact on all plants.

\section{Growth rates}

Changes in the green foliage area of tussocks were estimated from dimensional measures of each leaf blade and sheath on ten permanently marked tillers within each tussock on successive dates (see Chapter II for details). Specific growth rates were calculated as the net change in green foliage area on each tiller divided by the absolute amount of green foliage area present on that tiller at the 
beginning of the growth period (after Thornley 1976) (Chapter II). The specific growth rates of the ten tillers were averaged and considered to be representative of the entire tussock. The number of tillers per tussock ranged from 150 to 350 . The term growth rate used in this chapter refers to the calculated specific growth rate $\left(\mathrm{cm}^{2} \mathrm{~cm}^{-2}\right.$ $\mathrm{d}^{-1}$ ). Growth rates were calculated for two successive 14-d periods following defoliation. The amount of green foliage area on each tussock was estimated before and after clipping using inclined point quadrats (Warren Wilson 1960, 1963, Caldwell et al. 1983b). These estimates of green foliage area were used to put whole-canopy gas exchange measurements on a unit foliage area basis.

\section{Canopy gas exchange}

Carbon dioxide and water vapor exchange of each tussock canopy was monitored for the first half of the daylight period and an entire nighttime period prior to defoliation. Instead of replicating ambient air temperatures, which vary from day-to-day, a constant air temperature of 20 C was maintained in the measuring chambers during the day. The constant temperature reduced differences in the conditions for gas exchange measurement among the plant sets. Constant temperature was also maintained to allow the examination of tussock photosynthetic response to varying irradiance without changes in other environmental factors. Nighttime air temperatures were also kept at $20 \mathrm{C}$ to allow the 
estimation of daytime dark respiration rates from those measured at night (e.g. Woledge and Parsons 1986a). Leaf-toair gradients of water vapor concentration were maintained within the range of .017 to $.023 \mathrm{~mol} \mathrm{~mol}^{-1}$ during the day. The day following defoliation, gas exchange was measured for an entire $24-\mathrm{h}$ period with the same chamber conditions.

Gas exchange was measured in four $0.15-\mathrm{m}^{3}$ semicylindrical plexiglas cuvettes in an open gas exchange system. Air was almost completely dehumidified (dew point = -25 C) with heatless driers (Puregas Co.) before entering the chambers. Because the driers also removed a substantial amount of $\mathrm{CO}_{2}$, the dry air was mixed with a low flow rate of pure $\mathrm{CO}_{2}$ to maintain a $\mathrm{CO}_{2}$ concentration of about $360 \mathrm{ul}$ $1^{-1}$ in the incoming air. The concentration of $\mathrm{CO}_{2}$ in the chamber air varied from 330 to 360 ul $1^{-1}$ during the $24-\mathrm{h}$ period. The flow rate of the dry incoming air was used to control the water vapor concentration of the chamber air. The flow rate of incoming air was monitored with a pneumotachometer (Hans Rudolph Co.) and a pressure transducer (Validyne Co.). The air was sent to the cuvettes through stainless steel pipes and teflon hoses, and the interior of the cuvettes was covered with a clear teflon film to minimize adsorption of $\mathrm{CO}_{2}$ and water vapor. A constant flow of sample chamber air was pumped to various instruments for analysis. Water vapor concentrations of the ingoing and outgoing air streams were calculated from measurements of relative humidity with thin-film capacitance 
sensors (Vaisala Co.) and air temperature measured with platinum resistance thermometers (Omega Co.). The difference in $\mathrm{CO}_{2}$ concentration of the two air streams was monitored with an infrared gas analyzer (Analytical Development Co.) in the differential mode. The absolute $\mathrm{CO}_{2}$ concentration of the incoming air was measured twice daily with the gas analyzer. Leaf temperatures were measured with four fine-wire thermocouples inserted into different leaves and joined in parallel to average the temperatures of those leaves. Photosynthetic photon flux density was measured within each chamber with a quantum sensor (Licor Co.) placed immediately above the tussock canopy. chamber air temperatures were maintained with a microprocessorcontrolled Peltier heat exchange system mounted on the north side of each cuvette. The chamber walls were sealed at the soil surface around the tussock and a positive pressure in the chamber was maintained to prevent gas efflux from the soil (Leafe 1972). All data were automatically digitized and recorded every ten seconds and averaged over a fourminute interrogation period for each chamber. The sample air streams from all four chambers flowed to the analysis equipment in separate lines. These air lines converged at a gas switch adjacent to the instruments in order to minimize the time required to change the air stream being sampled among chambers. After switching sample air streams, a settling time of sixty seconds was allowed before data were recorded. 
Gas exchange calculations followed those of voncaemmerer and Farquhar (1981). In order to compare tussocks with different amount of foliage, canopy gas exchange rates were calculated on a unit green foliage area basis (e.g., umol $\mathrm{CO}_{2} \mathrm{~m}^{-2}$ foliage area $\mathrm{s}^{-1}$ ). The total amount of $\mathrm{CO}_{2}$ exchange by an entire tussock (umol $\mathrm{CO}_{2}$ tussock $\mathrm{s}^{-1}$ ) was also calculated and is referred to as whole-tussock $\mathrm{CO}_{2}$ uptake.

Twenty-four-hour time courses of canopy $\mathrm{CO}_{2}$ exchange rates (CER; umol $\mathrm{CO}_{2} \mathrm{~m}^{-2}$ foliage area $\mathrm{s}^{-1}$ ) were separated into a daytime period of net $\mathrm{CO}_{2}$ uptake $\left(\mathrm{CER}_{\mathrm{d}} ; \operatorname{mol} \mathrm{CO}_{2} \mathrm{~m}^{-2}\right.$ ) and a nighttime period of $\mathrm{CO}_{2}$ efflux $\left(\mathrm{CER}_{\mathrm{n}} ; \operatorname{mol} \mathrm{CO}_{2} \mathrm{~m}^{-2}\right)$. The $\mathrm{CO}_{2}$ exchange rates for each period were integrated over the time interval to obtain the total net $\mathrm{CO}_{2}$ exchange per unit foliage area for that period. The daytime values of net $\mathrm{CO}_{2}$ uptake were doubled for the predefoliation measurements because uptake was only measured for the first half of the daytime period. For days where $\mathrm{CO}_{2}$ exchange was measured through the entire daytime period (after clipping), doubling of measurements over the first half of the daytime period resulted in integrated values of $\mathrm{CO}_{2}$ exchange within seven percent of the actual daytime $\mathrm{CO}_{2}$ exchange. Net daily carbon gain $\left(\mathrm{CER}_{24}\right)$ was calculated as the difference between daytime $\mathrm{CO}_{2}$ uptake and nighttime $\mathrm{CO}_{2}$ efflux $\left(\mathrm{CER}_{\mathrm{d}}-\mathrm{CER}_{\mathrm{n}}\right)$. Fractional changes (postclip / preclip) in gas exchange parameters (e.g., $C E R_{d}, C E R_{n}, C E R_{24}$ ) were examined because of differences in gas exchange among the tussocks 
prior to defoliation. These fractional changes were not directly comparable among the replicate plant sets because of day-to-day variations in solar irradiance. Thus, the fractional change of each plant was relativized to the fractional change of the control plant of that set. This resulted in relative values of 1.0 for all control plants.

Differences in fractional changes among clipping patterns were tested with analysis of variance in a randomized block design (replicate plant sets $=$ blocks) and linear contrasts. The difference between each clipping pattern and control plants was evaluated by testing the hypothesis that the treatment mean was equal to 1.0 . Mean differences are reported as significant when $P<.05$.

Results

\section{Canopy $\mathrm{CO}_{2}$ exchange}

Net daily carbon gain $\left(\mathrm{CER}_{24}\right)$ immediately following defoliation was positively related to tussock regrowth rates over the first two weeks after clipping (Fig. 8). The plants from which lower leaf blades were removed exhibited both the highest $\mathrm{CER}_{24}$ and the highest regrowth rates. The set of plants which was measured last was not included in this relationship (within dotted line in Fig. 8). Three of these plants had low regrowth rates despite having high values of $\mathrm{CER}_{24}$. This was due to the diversion of fixed carbon from foliage regrowth into inflorescence and seedhead production, which was substantially advanced when this set of plants was 


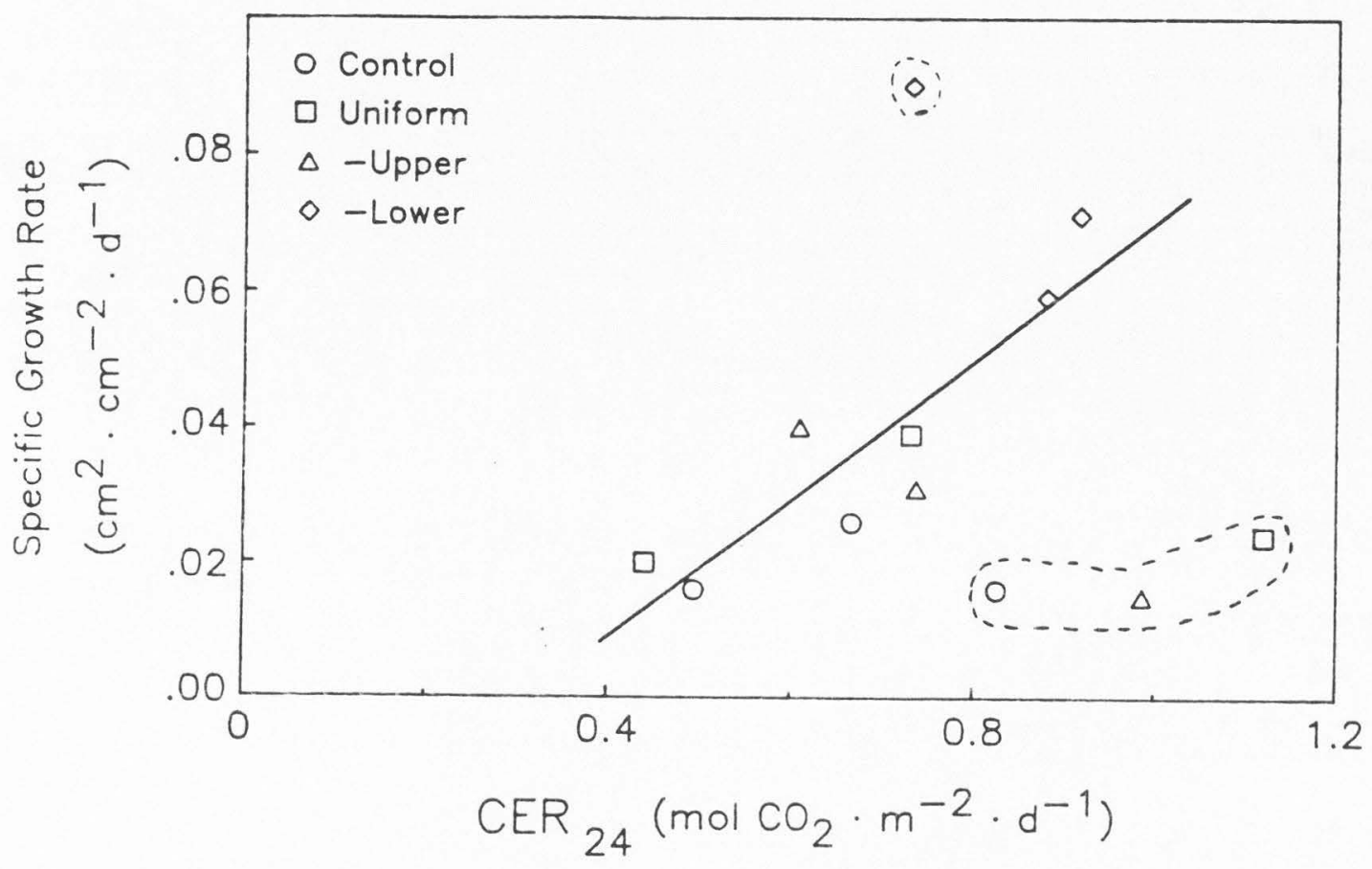

Fig. 8. The relationship between 24 -h net carbon gain the day after clipping and the specific growth rate of each of the 12 tussocks over the first 14 d following defoliation. The plants from the final experimental set (within dotted line) were not included in the relationship because much of the regrowth of these plants was in unmeasured reproductive structures $\left(r^{2}=0.81, P<.01\right)$. 
defoliated. The regrowth rates of these three plants appear low because the measures of growth used in this study did not include reproductive parts of the plant. The reason for the high regrowth rate of the -lower plant of the third set of plants is unknown.

All clipped plants showed an increase in CER 24 following defoliation relative to control plants (Fig. 9a). This increase was significantly greater for the -lower plants (62 \%) than for plants of the other clipping patterns (15 and $20 \%$ ). The relative increases in $\mathrm{CER}_{24}$ were not significantly different between the uniform and -upper clipping treatments.

Net $\mathrm{CO}_{2}$ uptake during the daytime $\left(\mathrm{CER}_{\mathrm{d}}\right)$ responded to the defoliations in a similar manner as did CER 24 (Fig. 9b). All clipped plants showed an increase in CER d relative to control plants, and this increase was significantly greater where lower leaf blades were removed. There was no significant difference in the effect of uniform or -upper defoliations on $\mathrm{CER}_{\mathrm{d}}$.

Nighttime $\mathrm{CO}_{2}$ efflux (CERn) also increased significantly in plants of all clipping patterns (Fig. 9c). Although the relative increases in $\mathrm{CER}_{n}$ were large (200 to $250 \%)$, the increases in the amount of $\mathrm{CO}_{2}$ given off at night were small compared to the increases in the amount of $\mathrm{CO}_{2}$ taken up during the daytime. For example, the average increase in $\mathrm{CER}_{\mathrm{d}}$ for the -lower plants was $406 \mathrm{~mol} \mathrm{CO}_{2} \mathrm{~m}^{-2}$, while the increase in $\mathrm{CER}_{\mathrm{n}}$ for those plants was only $59 \mathrm{~mol}$ 

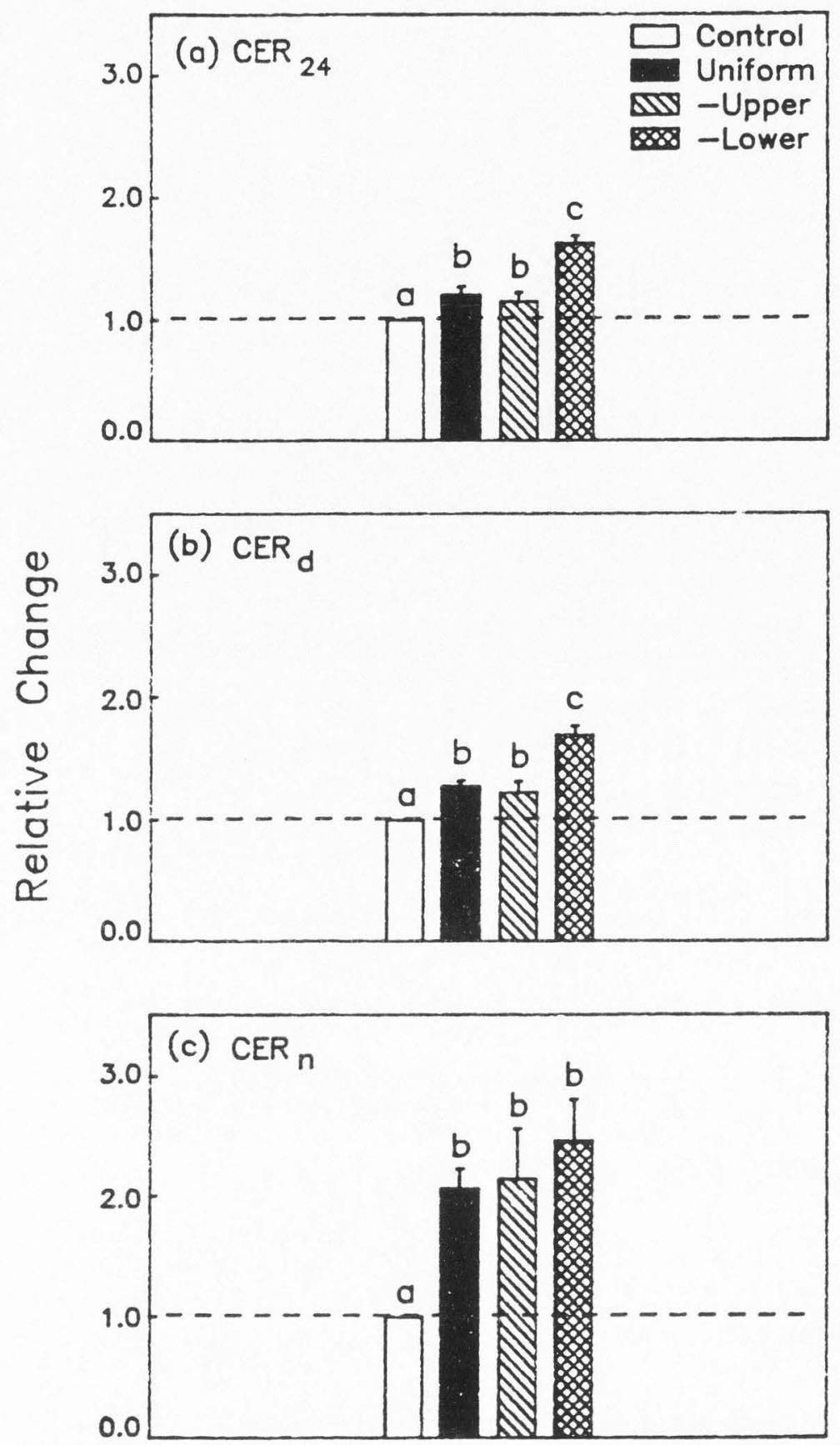

Fig. 9. The fractional change following defoliation (postclip/preclip) in (a) 24-h net carbon gain (mol $\mathrm{CO}_{2}$ $\mathrm{m}^{-2}$ ), (b) daytime net $\mathrm{CO}_{2}$ uptake (mol $\mathrm{m}^{-2}$ ), and (c) nighttime $\mathrm{CO}_{2}$ efflux (mol $\mathrm{m}^{-z}$ ). The fractional changes were normalized to the changes of the control plants, therefore, there is a relative change of 1.00 for the control plants (shown with dotted lines). Mean values of 3 tussocks are shown for each treatment with the standard error. Letters indicate significant differences ( $P<.05$ ) among means by analysis of variance and linear contrasts. 
$\mathrm{CO}_{2} \mathrm{~m}^{-2}$. There were no significant differences among the clipping treatments in the increase of $\mathrm{CER}_{\mathrm{n}}$ (Fig. 9C). Thus, the differences among clipping patterns in the relative change in $\mathrm{CER}_{24}$ were the result of differences in daytime $\mathrm{CO}_{2}$ uptake rather than differences in nighttime $\mathrm{CO}_{2}$ efflux.

The gas exchange of one set of plants was also measured 7 d following defoliation. These data allow an examination of the changes in tussock $\mathrm{CO}_{2}$ exchange during a period of regrowth. Although daytime $\mathrm{CO}_{2}$ uptake per unit foliage area ( CER $;$ mol $\mathrm{CO}_{2} \mathrm{~m}^{-2}$ ) of defoliated tussocks increased immediately after clipping (Fig. 10a; day 0 to day 1), this only partially compensated for the amount of foliage removed. Whole-tussock $\mathrm{CO}_{2}$ uptake during the daytime (mol $\mathrm{CO}_{2}$ tussock ${ }^{-1}$ ) of clipped plants declined immediately following defoliation relative to the control tussock (Fig. 10b; day 0 to day 1). Whole-tussock $\mathrm{CO}_{2}$ uptake by the -lower plant declined less (day 0 to day 1) and recovered faster during regrowth (day 1 to day 7) than the uniform or -upper plants (Fig. 10b). In contrast, carbon dioxide uptake per unit foliage area $\left(C E R_{d}\right)$ increased at the same rate for all clipped tussocks during the regrowth period (days 1 to 7) (Fig 10a). The differences among clipping treatments in $\mathrm{CER}_{\mathrm{d}}$ during the regrowth period (Fig. 10a; day 1 to day 7) were a result of the initial effect of clipping on $\mathrm{CER}_{\mathrm{d}}$ (day 0 to day 1 ). 


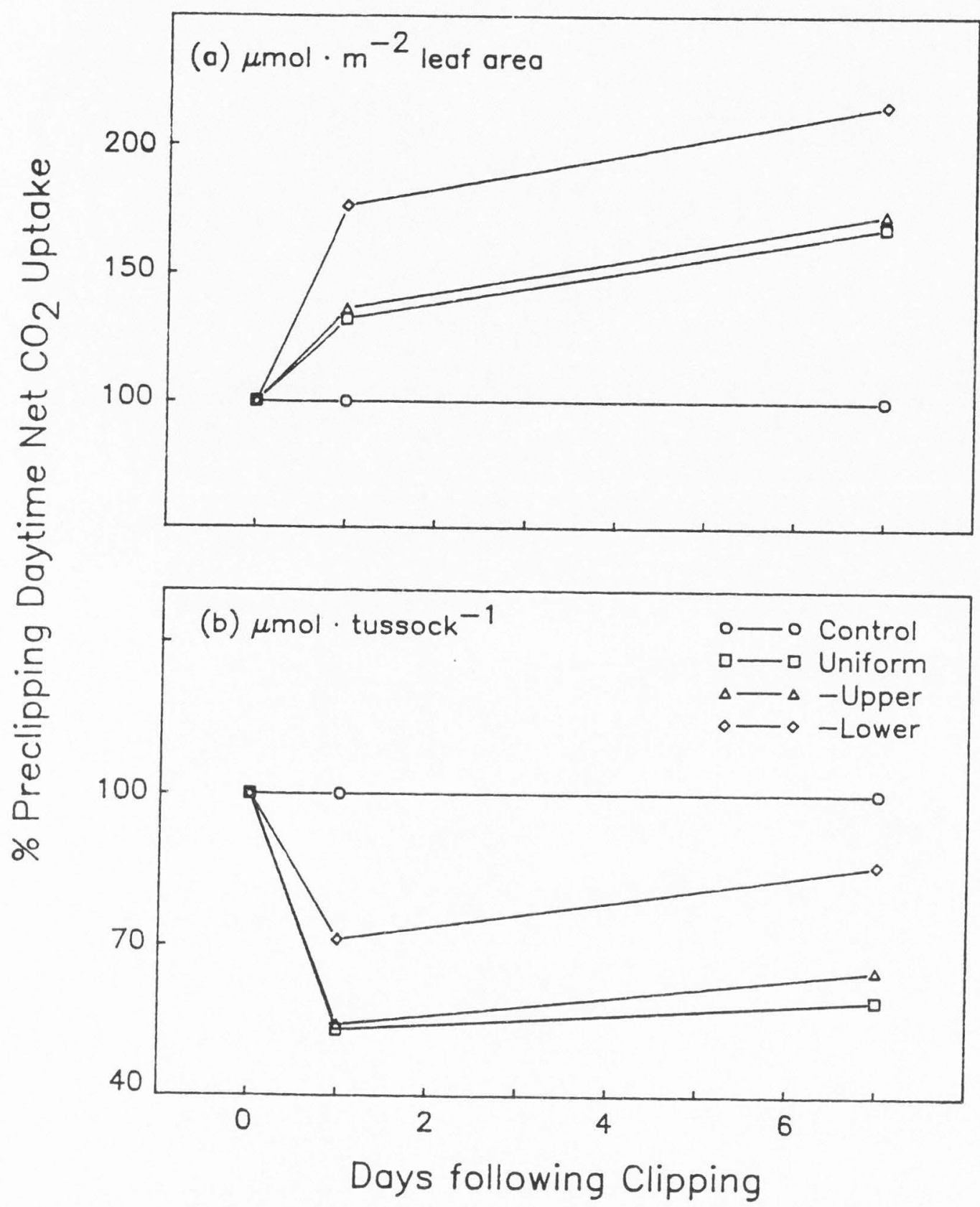

Fig. 10. Percent change in daytime $\mathrm{CO}_{2}$ uptake from predefoliation measurements for (a) tussock assimilation per
unit foliage area (mol $\mathrm{CO}_{2} \mathrm{~m}^{-2}$ ) and (b) whole-tussock
assimilation (mol $\mathrm{CO}_{2}$. Meas assimilation (mol one tussock of and after climent and were taken the days immediately before and after clipping and 7 d after clipping. All values were normalized to the control plants, therefore, there is a value of 100 percent for the control plants through the
regrowth period. 
Water-use efficiency

Integrated values of canopy water-use efficiency (WUE) were calculated from net $\mathrm{CO}_{2}\left(\mathrm{CER}_{\mathrm{d}}\right)$ and water vapor $\left(\mathrm{E}_{\mathrm{d}}\right)$ exchange integrated over the daytime period. The fractional change (preclip/postclip) in WUE for the uniform and -upper defoliation plants was less than the fractional change in WUE for control plants (Fig. 11). The fractional change in WUE of the -lower plants was not different $(P=0.14)$ from the control plants. Following defoliation the -lower tussocks had both higher specific growth rates and higher WUE than the uniform and -upper tussocks (Fig. 11). The third set of tussocks were not included in this evaluation because of the unreliability of those regrowth measurements, as mentioned previously for Figure 8.

Relative increases in daytime tussock water loss ( $\left.E_{d}\right)$ ranged from 61 to 100 percent following defoliation, but these increases were not significantly different among the clipping patterns (Fig. 12a). Thus, the high values of WUE shown by the -lower plants for their high regrowth rates (Fig. 11) resulted from greater increases in CER d (Fig. 9b) rather than differences in $E_{d}$ (Fig. 12a).

\section{Conductance and intercellular}

\section{$\mathrm{CO}_{2}$ concentration}

Conductance to water vapor $\left(g_{W} ; \operatorname{mol~} \mathrm{H}_{2} \mathrm{O} \mathrm{m}^{-2}\right.$ foliage area $\mathrm{s}^{-1}$ ) and intercellular $\mathrm{CO}_{2}$ concentration $\left(\mathrm{c}_{i} ; \mathrm{ul} \mathrm{I}^{-1}\right.$ ) of tussocks were calculated using an analogous method to that used for a single leaf (voncaemmerer and Farquhar 

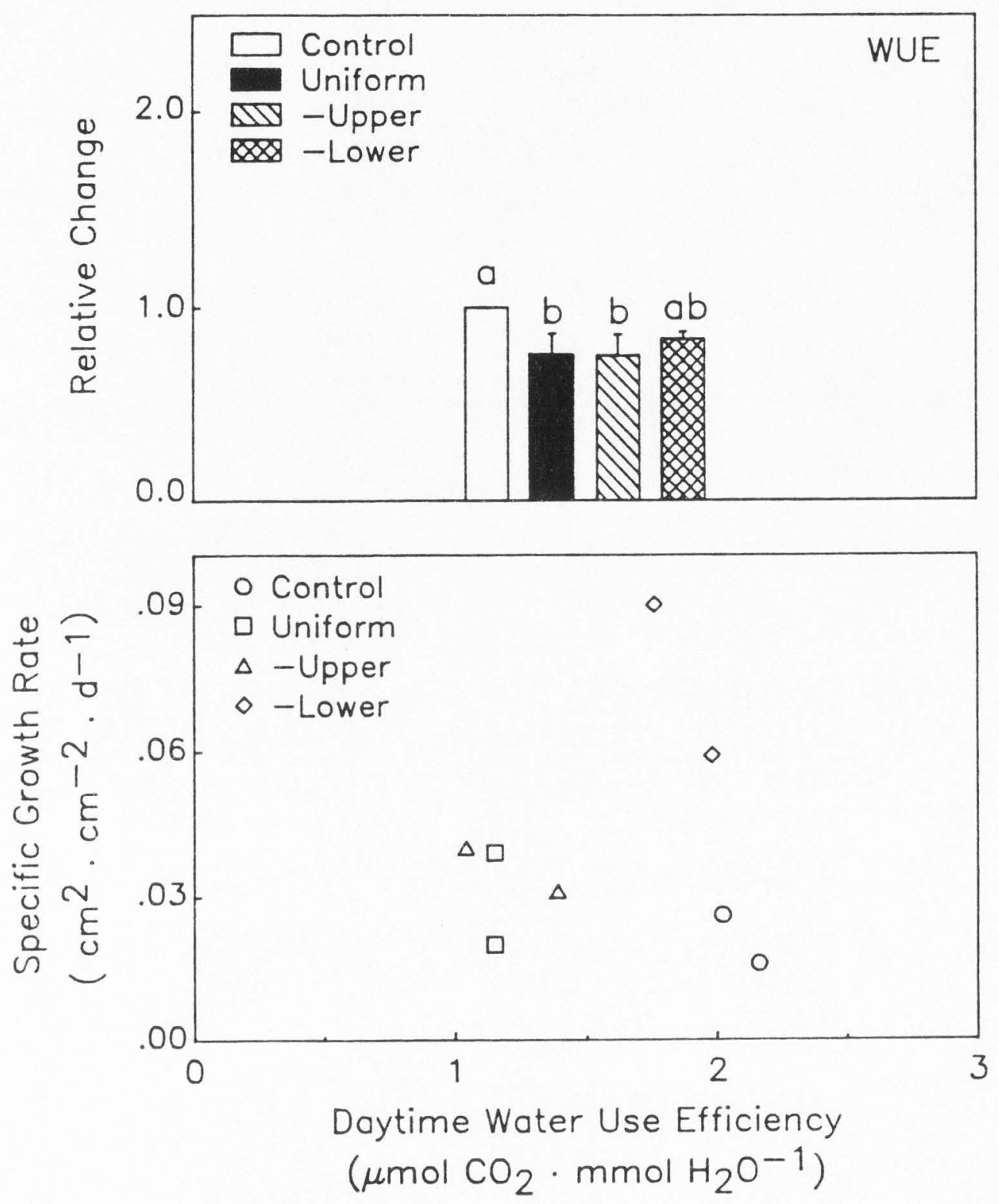

Fig. 11. The fractional change in daytime water-use efficiency ( $W U E=C E R$ d $/ E_{d}$ ) following defoliation of treatment tussocks (postclip/preclip) (upper panel). The fractional changes were normalized to the changes of the control plants, resulting in a relative change of 1.00 for the control plants. Mean values of 3 tussocks are shown for each treatment with the standard error. Letters indicate significant differences $(P<.05)$ among means by analysis of variance and linear contrasts. The association between WUE and the specific growth rates of each of the 12 tussocks over the first 14 d following clipping of treatment plants is shown in the lower panel. The third set of tussocks was not included because of the unreliability of regrowth measures (see text for Fig. 8). 

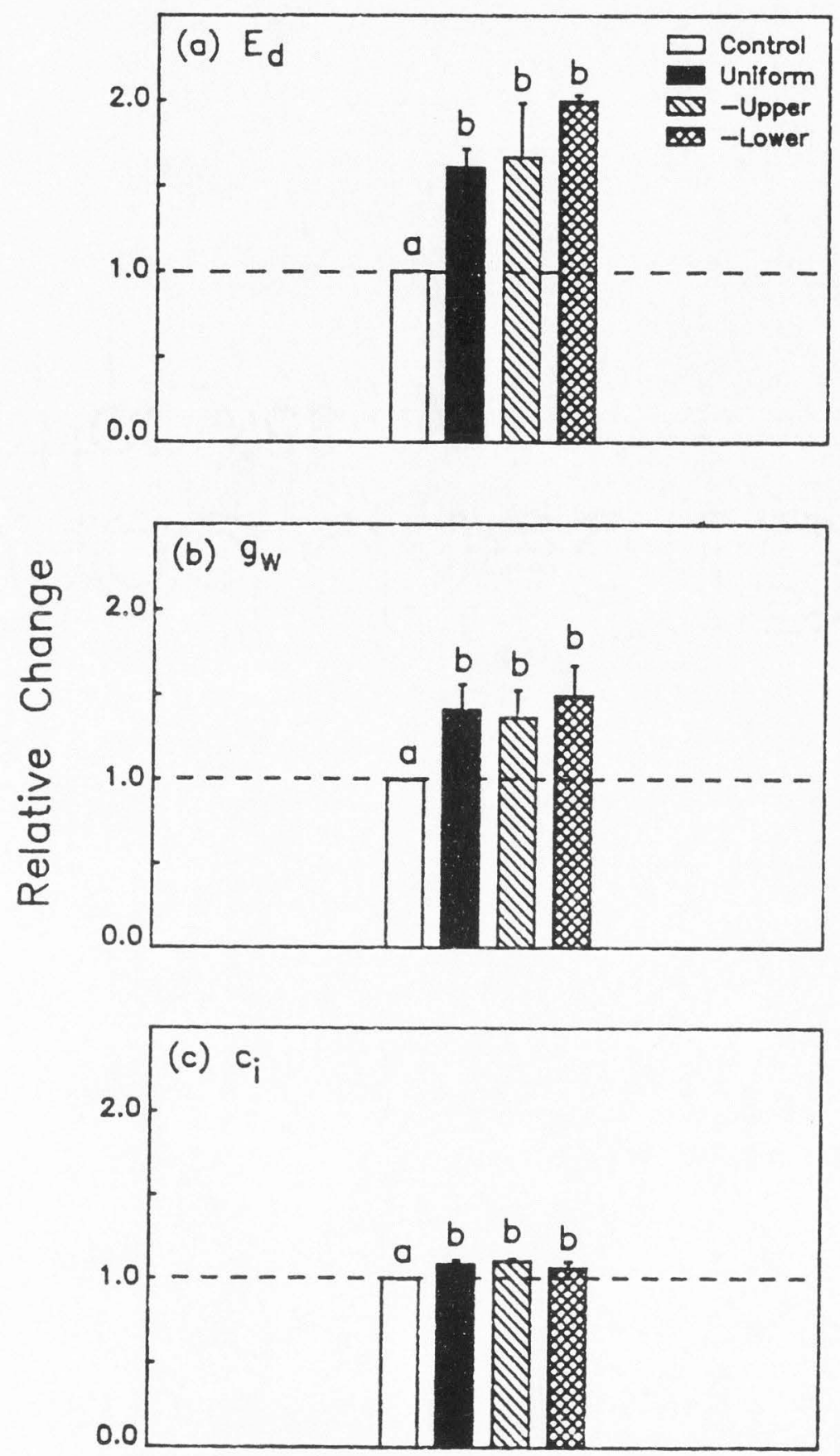

Fig. 12. The fractional change following defoliation (postclip/preclip) in (a) daytime water vapor loss (mol $\mathrm{m}^{-2}$ ), (b) conductance to water vapor ( $\mathrm{mol} \mathrm{m}^{-2} \mathrm{~s}^{-1}$ ), and (c) intercellular $\mathrm{CO}_{2}$ concentration ( $\mathrm{ul}^{-1}$ ). The values of (b) conductance and (c) intercellular $\mathrm{CO}_{2}$ are averages over the middle $10 \mathrm{~h}$ of the daytime period. The fractional changes were normalized to the changes of the control plants, resulting in a relative change of 1.00 for the control plants (shown with dotted lines). Mean values of 3 tussocks are shown for each treatment with the standard error. Letters indicate significant differences ( $\mathrm{P}<.05$ ) among means by analysis of variance and linear contrasts. 
1981). The average values of $g_{W}$ and $c_{i}$ through the middle $10 \mathrm{~h}$ of each day immediately before and after clipping are presented in Table 4. The middle $10 \mathrm{~h}$ of each day were used to calculate these average values because that is the period of high irradiance, during which $g_{W}$ and $c_{i}$ are relatively stable and most of the $\mathrm{CO}_{2}$ fixation takes place. The values of $g_{W}$ and $c_{i}$ the day after clipping are also presented relative to both preclipping values and the fractional changes in control plants for the same reasons that the $\mathrm{CO}_{2}$ exchange values were presented in that form (Fig. $12 \mathrm{~b}$ ). There was a significant increase in $g_{w}$ following defoliation, which ranged from 37 to 50 percent, but the magnitude of increase was not significantly different among the clipping patterns (Fig. 12b). The responses of $g_{W}$ among treatments qualitatively paralleled the responses seen in $\mathrm{E}_{\mathrm{d}}$ (Fig. 12a). This is not surprising because water vapor concentration gradients between the leaf and air were held relatively constant.

The average tussock $c_{i}$ of clipped tussocks increased significantly following defoliation (Fig. 12c) relative to control plants. The increases in $c_{i}$, which ranged from 6 to 10 percent $\left(15-30\right.$ ul $\left.1^{-1}\right)$, were not significantly different among the clipping treatments.

Discussion

Defoliation spatial pattern and canopy $\mathrm{CO}_{2}$ exchange

I have shown earlier that the spatial pattern in which 
Table 4. Conductance to water vapor $\left(g_{W}\right)^{*}$ and intercellular $\mathrm{CO}_{2}$ concentration $\left(\mathrm{C}_{i}\right)^{\star *}$ for tussocks averaged over the middle $10 \mathrm{~h}$ of the day.

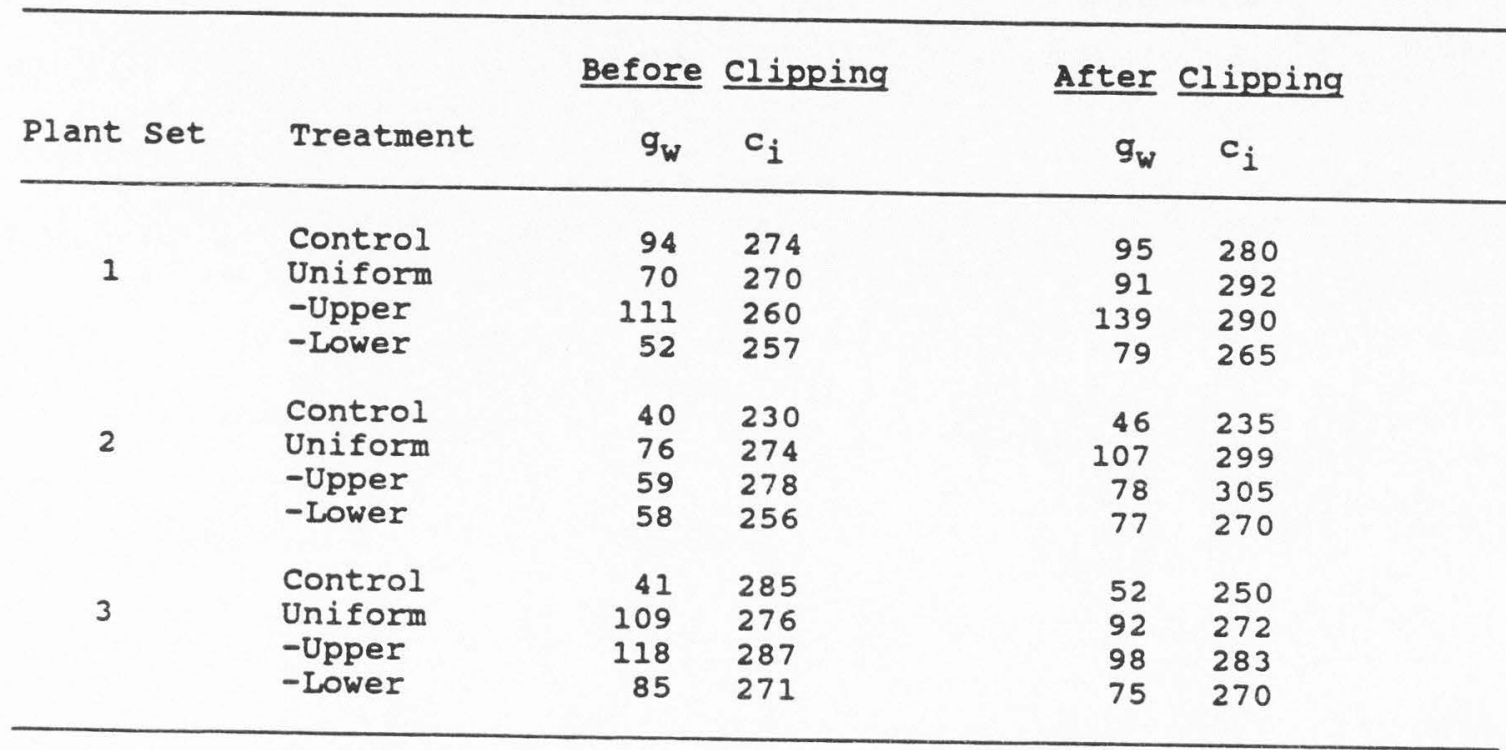

* mmol $\mathrm{H}_{2} \mathrm{O} \mathrm{m}^{-2} \mathrm{~s}^{-1}$

** ul $1^{-1}$ 
foliage is removed from a tussock grass can make a substantial difference in canopy regrowth rates (chapter II). From this study it appears likely that the clipping patterns directly affected regrowth through influences on daytime $\mathrm{CO}_{2}$ uptake. The different regrowth responses among the mid-May clipping patterns shown in chapter II were paralleled by the responses of $C_{24}$ and $C E R_{d}$ in this experiment. The few other field studies which have involved measurement of whole-canopy daily $\mathrm{CO}_{2}$ exchange and regrowth have also found a good correlation between net daily $\mathrm{CO}_{2}$ exchange and regrowth of grass swards (Ludlow and CharlesEdwards 1980, Parsons et al. 1983, King et al. 1984). Studies which have only examined the photosynthetic response of individual leaves following defoliation have not always been successful in relating $\mathrm{CO}_{2}$ exchange to regrowth (e.g. Detling and Painter 1983, Nowak and Caldwell 1984).

The strong correspondence between foliage regrowth and $\mathrm{CER}_{\mathrm{d}}$ in this study suggests that regrowth was constrained by $\mathrm{CO}_{2}$ fixation. The study was carried out in the spring, when availability of water and mineral nutrients was not likely to limit regrowth at our field site. In other experiments at this field site, fertilization of $\underline{A}$. desertorum tussocks with nitrogen and phosphorus in the spring of a year with high precipitation did not cause any measurable growth increases in the tussocks (Mazurski, unpublished data). In addition, the morphological constraints to regrowth were minimized in all clipping patterns because apical meristems 
were left intact (Briske 1986). Thus, substrate carbon probably was the primary factor limiting regrowth in $\underline{A}$. desertorum. The primary source of carbon for regrowth in $\underline{A}$. deseetoㅡㅁㅡ is current photosynthate because labile carbon pools are quite small when compared with daily net $\mathrm{CO}_{2}$ uptake of regrowing plants which were even more severely defoliated ( $85 \%$ foliage removal) than those used in this experiment (Richards and Caldwell 1985). The importance of current photosynthate for regrowth has also been demonstrated for other grasses (Marshall and Sagar 1965, Davidson and Milthorpe 1966, Ryle and Powell 1975). The rate with which photosynthetic surfaces are reestablished will have a compounding effect on long-term regrowth rates (Davidson and Milthorpe 1966, Caldwell et al. 1981). In fact, tussock regrowth rates over a two-week period in this study were positively related to the net daily carbon gain of tussocks during the first $24 \mathrm{~h}$ following defoliation (Fig. 8).

Shifts in the allocation of carbon to favor aboveground plant parts at the expense of the root system are common following the defoliation of some grasses (Davidson and Milthorpe 1966, Richards 1984). The allocation of carbon to belowground plant parts was not measured in this study. Differential shifts in root:shoot carbon allocation among plants receiving the different defoliation patterns could make the comparison of daily carbon gain and foliage production difficult. However, differential shifts in 
aboveground versus belowground allocation are unlikely because the same quantity of foliage was removed in the various clipping patterns.

All of the defoliation patterns used in this study resulted in similar large increases in tussock dark respiration per unit foliage area $\left(C E R_{n}\right)$ (Fig. 9c). These increases were large enough that the integrated $\mathrm{CO}_{2}$ efflux per tussock did not change after defoliation compared to control plants. Increases in $\mathrm{CER}_{\mathrm{n}}$ could have been due to an increase in the proportional allocation of carbon to the shoot rather than the roots following defoliation (Richards 1984). Increases in soluble protein concentrations following defoliation, which have been demonstrated for regrowing foliage of A. desertorum (Nowak and Caldwell 1984), could also cause increased respiration because of maintenance costs associated with protein turnover (Amthor 1984). The mechanisms responsible for these increases in $\mathrm{CER}_{\mathrm{n}}$ must have responded rapidly to the defoliation because $C E R_{n}$ increased within the first $24 \mathrm{~h}$ following clipping. Unfortunately, there is no information on the dynamics of changes in carbon allocation or soluble protein accumulation following defoliation. Transient increases in dark respiration due to physical damage of foliage caused by clipping have been observed (Macnicol 1976). The contribution of clipping damage to increased dark respiration in this experiment was probably minor because the immediate increase in $C E R_{n}$ was maintained at the same 
high level 7 d after defoliation in clipped tussocks (data not shown).

The response of foliage dark respiration rates to partial defoliation has not been consistent among other studies. Experimental defoliation of deciduous trees (Heichel and Turner 1983) and some grasses (Atkinson 1986) has resulted in increases of both photosynthesis and dark respiration in single leaves. However, others have reported increased photosynthetic rates with no increases in respiration (Detling et al. 1979, Ludlow and Charles-Edwards 1980, Wallace et al. 1984). Although the relative increases in dark respiration after clipping were quite large in my study, they were of little significance for changes in $24-\mathrm{h}$ tussock $\mathrm{CO}_{2}$ exchange. Increases in the amount of daytime $\mathrm{CO}_{2}$ uptake following defoliation were nearly an order of magnitude larger than the increases in the amount of $\mathrm{CO}_{2}$ lost at night.

Changes in tussock $\mathrm{CO}_{2}$ exchange were probably the result of a complex interaction among canopy structure, light interception, and the physiological characteristics of remaining and regrowing foliage. The relationship among defoliation pattern, canopy photosynthesis, and such factors is described in chapter IV.

\section{Water-use efficiency and regrowth}

The WUE of whole tussocks is affected by the light environment and spatial distribution of foliage within the 
tussock in addition to the gas exchange behavior of individual foliage elements. These factors may be affected in a variety of ways with different defoliation patterns. Caldwell et al. (1983a) found decreases in WUE following a severe (85\% foliage removal) uniform defoliation of $\underline{A}$. desertorum tussocks. Although the defoliation eliminated self-shading within the tussock, the remaining foliage was old and exhibited low values of WUE. Caldwell et al. (1983a), however, postulated that a more selective herbivore might be able to reduce tussock self-shading without decreasing the proportion of more productive foliage elements and thus improve tussock wUE.

I did not find an increase in WUE with any of the defoliation patterns used in this study. The WUE of all tussocks was decreased by defoliation (Fig. 11). Thus, the enhanced regrowth rates of these clipped tussocks were achieved at the expense of a low water-use efficiency of $\mathrm{CO}_{2}$ assimilation. The reduced WUE of defoliated tussocks was also indicated by increases in $c_{i}$ (Fig. 12C). This occurred at a time of year when water was not limiting for growth. The benefits of maintaining a high wUE under such conditions are questionable. Caldwell et al. (1983a) have argued that postponing water use with a high wUE might only result in the loss of that water to competitors or use of that water at a later time when increasingly stressful atmospheric conditions would result in a lower WUE. 
$\underline{\text { Conductance }} \underline{\text { fixation }} \underline{\mathrm{CO}_{2}}$

Foliage conductance of tussocks in this study ranged from 40 to $118 \mathrm{mmol} \mathrm{H}_{2} \mathrm{O} \mathrm{m}^{-2} \mathrm{~s}^{-1}$ prior to defoliation (Table 4). This is considerably below the maximal $g_{W}$ values of 200-250 mmol $\mathrm{H}_{2} \circ \mathrm{m}^{-2} \mathrm{~s}^{-1}$ for single leaves of $\underline{A}$. desertorum reported by Nowak and Caldwell (1986). On the whole-canopy level, $g_{W}$ is a function of both the average physiological characteristics of all foliage elements in the canopy and the canopy microclimate. The conductance values measured here for whole tussocks are lower than the maximum $g_{W}$ of single leaves because they reflect the inclusion of older foliage and the large proportion of shaded foliage within the tussock (Caldwell et al. 1983a).

The differential increases in $\mathrm{CER}_{\mathrm{d}}$ among the clipping patterns in this study (Fig. 9b) certainly cannot be attributed to stomatal responses. Conductance and $c_{i}$ increased equally among tussocks of all clipping patterns (Fig. 12b, $\mathrm{c}$ ). Increases in $\mathrm{g}_{\mathrm{w}}$ for a whole canopy following defoliation can be the result of a number of processes. Shifts in foliage age structure toward a higher proportion of younger foliage could increase $g_{W}$ because younger leaves

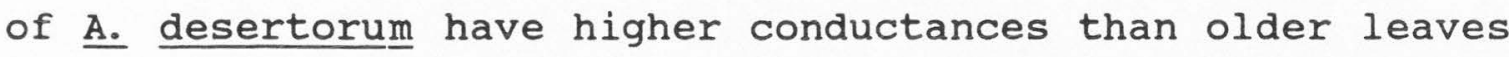
(Caldwell et al. 1983a, Nowak and Caldwell 1986). Improved leaf water status of remaining foliage, resulting from a decreased shoot:root ratio, could lead to increased $g_{W}$. However, water availability is not a substantial problem during the spring (early April to early June) at this site 
(Caldwell et al. 1981). Additionally, Nowak and Caldwell (1984) reported no difference in the water status of foliage

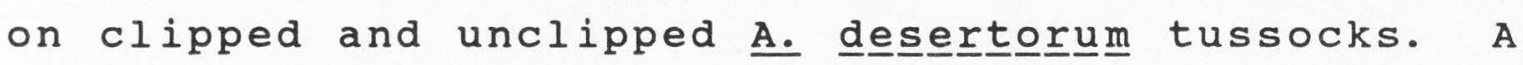
reduction in the proportion of foliage shaded within the tussock could also increase $g_{W}$ (Caldwell et al. 1983a). Increases in stomatal conductance of leaves remaining after defoliation, without any changes in the irradiance of those leaves, have also been observed (Gifford and Marshall 1973, Detling and Painter 1983, wallace et al. 1984). A combination of factors is probably responsible for the observed increases in $g_{W}$.

Many studies have concluded that increases in $g_{\mathrm{W}}$ were the cause of increased rates of $\mathrm{CO}_{2}$ fixation in remaining and regrowing foliage (Gifford and Marshall 1973, Heichel and Turner 1983, Wallace et al. 1984). Unfortunately, the basis for that conclusion was simply a correlation between increases in $g_{W}$ and net photosynthesis. No measures of mesophyll photosynthetic activity were reported. Without information on mesophyll photosynthetic activity, it is difficult to conclude much about the importance of increased $\mathrm{g}_{\mathrm{W}}$ for increased photosynthesis. For instance, the midday decline in photosynthesis of some Mediterranean shrubs during the summer is accompanied by both stomatal closure and a decrease in mesophyll photosynthetic activity (Tenhunen et al. 1984).

Differential changes in mesophyll photosynthetic activity among the clipping treatments could also be 
responsible for the differential responses of $C E R_{d}$. Changes in the age structure of tussock foliage and the canopy microclimate could affect the average mesophyll photosynthetic activity within a tussock. Increases in soluble protein concentrations after clipping (Nowak and Caldwell 1984), could also affect mesophyll photosynthetic activity. The physiological basis for the differential changes in $C E R_{d}$ among the clipping patterns needs further investigation.

\section{Whole-tussock carbon gain}

There has been substantial documentation of increases in photosynthesis per unit area of individual leaves following defoliation (Dyer et al. 1982, MCNaugton 1983). However, the response of whole-plant $\mathrm{CO}_{2}$ uptake through a period of regrowth has been reported in only a couple of cases (Detling et al. 1979, Parsons et al. 1983). In this study, the amount of $\mathrm{CO}_{2}$ fixed by the entire tussock during the daytime ( $m o l \mathrm{CO}_{2}$ tussock $^{-1}$ ) declined immediately after clipping (Fig. 10b) despite increases in $\mathrm{CO}_{2}$ uptake per unit foliage area (CER $)$ (Fig. 10a). Parsons et al. (1983) and Detling et al. (1979) also found that increases in photosynthetic rates per unit leaf area of intensely grazed grasses did not fully compensate for the amount of foliage removed.

The $\mathrm{CO}_{2}$ uptake of an entire tussock is a function of the $\mathrm{CO}_{2}$ uptake per unit foliage area (CER $)$ and the amount 
of foliage area present. During the first week of regrowth (days 1 to 7 ) in this study, whole-tussock $\mathrm{CO}_{2}$ uptake increased more rapidly in plants which had lower leaf blades removed than in uniform or -upper plants (Fig. 10b). However, there were no differences among clipping treatments in the rate of increase in $C \mathrm{R}_{\mathrm{d}}$ during that time period (Fig. 10a). Hence, the quicker recovery of whole-tussock $\mathrm{CO}_{2}$ uptake in the -lower plants must have been a result of higher rates of foliage reestablishment rather than more rapid increases in $C R_{d}$. The quicker foliage regrowth (days 1 to 7) of the -lower plants was associated with greater initial increase in $\mathrm{CER}_{\mathbf{d}}$ following defoliation (days 0 to 1 ) than in uniform or -upper plants. This suggests that the immediate influence of the spatial pattern of foliage removal on tussock CER $\mathrm{d}$ is quite important for subsequent rates of foliage regrowth and recovery of whole-tussock carbon gain. 
CHAPTER IV

THE EFFECTS OF THE SPATIAL PATTERN OF DEFOLIATION

ON REGROWTH OF A TUSSOCK GRASS:

III. PHOTOSYNTHESIS, CANOPY STRUCTURE, AND

LIGHT INTERCEPTION

Introduction

The physical structure of a foliage canopy can influence plant carbon dioxide fixation and growth (Monsi et al. 1973, Woledge and Parsons 1986b). In canopies of relatively sparse foliage, where nearly all leaves are fully exposed, canopy structure can affect the total amount of light intercepted (Ludlow and Charles-Edwards 1980, Joggi et al. 1983). However, in dense canopies, where considerable shading occurs, canopy structure principally affects the balance of sunlit and shaded foliage rather than the total amount of light interception (Monsi et al. 1973). Differences in the productivity of some agronomic cultivars have been associated with the effect of canopy structure on the proportions of sunlit and shaded foliage (Monsi et al. 1973, Bunce 1986).

The carbon dioxide fixation of dense canopies is also affected by the photosynthetic characteristics of individual leaves within the canopy. These photosynthetic characteristics are related to the age of the leaf (Woledge and Leafe 1976, Biscoe et al. 1975) and the environmental conditions under which that leaf develops (Woledge 1972, 1986). Acock et al. (1978) have shown that photosynthesis 
of an entire tomato canopy could not be accurately predicted from data on the canopy environment and the gas exchange characteristics of any single leaf. Canopy photosynthesis was succesfully modelled only when information on the gas exchange of different-aged leaves was incorporated.

The removal of leaves of different ages by selective herbivores could have important implications for plant regrowth (Janzen 1979, Dirzo 1984). Controlled experiments using artificial defoliation have shown that the removal of younger leaves is more detrimental than the removal of older leaves for the growth of a number of species (stickler and Pauli 1961, Brown et al. 1966, Kulman 1965, Mendoza et al. 1987). Also, I have demonstrated that the removal of younger foliage at the top of a tussock grass canopy can result in slower regrowth than the removal of older foliage located at the bottom of the tussock (Chapter II). These differences in growth were clearly related to effects of the spatial patterns of defoliation on tussock daytime carbon gain (CER ${ }_{d}$; Chapter III). The spatial pattern of foliage removal could influence carbon gain through effects on canopy structural attributes and the relative amounts of different-aged foliage. In order to understand the basis for the observed changes in $C R_{d}$ and regrowth, this chapter examines the changes in canopy structure, light interception, foliage age structure, and tussock photosynthesis resulting from different spatial patterns of defoliation. 
Methods

\section{$\underline{\text { Study area }}$}

The study was conducted during the spring of 1986 at a field site in northern Utah, USA $\left(42^{\circ} \mathrm{N}\right.$ latitude, $1460 \mathrm{~m}$ above sea level) as described in Chapter II. Details of the study area are given in Caldwell et al. 1981.

\section{Defoliation treatments}

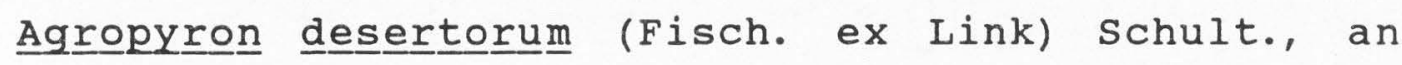
exotic tussock grass which has been extensively planted on semiarid rangelands throughout western North America, was used in the study. Twelve $\underline{A}$. desertorum tussocks were selected and divided into three replicate sets, each containing four plants. Three of the four plants in each set were clipped with scissors and the fourth plant was left intact as a control. The three replicate sets were clipped at $48 \mathrm{~h}$ intervals over a 5-d period (May 12-16, 1986). Therefore, the gas exchange of all four plants in a set could be simultaneously measured for the $24^{-h}$ periods immediately before and after clipping with the four gas exchange chambers. At the time of clipping the tussocks were still in a culmless state and contained considerable amounts of shaded foliage (Caldwell et al. 1983a). The three treatment plants within a set were each clipped in a different spatial pattern. In the uniform defoliation pattern, all tillers within the tussock were clipped to a 
uniform height. For the other two treatments, either the uppermost 2 to 3 green leaf blades (-upper), or the lowest 2 to 3 green leaf blades (-lower) were removed from every tiller on the tussock. Four to five green leaf blades were present on each tiller prior to defoliation. Approximately sixty percent of the tussock green foliage area was removed in all treatments (Chapter II, Table 1). The apical meristems were left intact on all tussocks.

\section{Canopy gas exchange}

Entire tussocks were individually enclosed in plexiglas chambers in the field for the measurement of canopy gas exchange. Carbon dioxide $\left(\mathrm{CO}_{2}\right)$ exchange of each tussock canopy was monitored for the first half of the daylight period and an entire nighttime period immediately before defoliation. These measurements were repeated for the entire 24-h period beginning the day after defoliation. A constant air temperature of $20 \mathrm{C}$ was maintained in the measuring chambers during both the day and night (see Chapter III). Daytime leaf-to-air water vapor concentration gradients were maintained in the range of .017 to $.023 \mathrm{~mol}$ $\operatorname{mol}^{-1}$. Details of the gas exchange measurement system are provided in chapter III.

The calculations of $\mathrm{CO}_{2}$ exchange rates follow those of voncaemmerer and Farquhar (1981). All $\mathrm{CO}_{2}$ exchange rates are expressed on a unit green foliage area basis (e.g. umol $\mathrm{CO}_{2} \mathrm{~m}^{-2}$ foliage area $\mathrm{s}^{-1}$ ). These $\mathrm{CO}_{2}$ exchange rates were also integrated over the daytime period (mol $\mathrm{CO}_{2} \mathrm{~m}^{-2}$ foliage 
area $d^{-1} ; C_{C E R}$ ) as described in chapter III.

Light dependencies of net photosynthesis were derived from measurements of net photosynthesis during the natural diurnal variation in light intensity. These data were fit to the Smith equation (Smith 1937, Tenhunen et al. 1976) by an iterative procedure (Dixon 1983). This allowed the estimation of the photosynthetic rate at maximum solar irradiance (2000 uE $\mathrm{m}^{-2} \mathrm{~s}^{-1} ; \mathrm{P}_{2000}$ ) and the intial slope of the light response curve (quantum efficiency) (Tenhunen et a 1. 1976).

Maximum photosynthetic rates $\left(\mathrm{P}_{2000}\right)$ and quantum efficiencies, as estimated from the smith equations, are given in Table 5. There were substantial differences among the tussocks in these parameters prior to defoliation. These differences could have been due to initial differences among tussocks in canopy structure and foliage physiological characteristics. Because of these initial differences in $\mathrm{P}_{2000}$ and quantum efficiency, the analysis of treatment effects was done with the fractional changes in the parameters (postclip value/preclip value). These fractional changes were not directly comparable among the replicate plant sets because of day-to-day variation in solar irradiance. Thus, the fractional change in these parameters for each plant was relativized to the fractional change of the control plant of that set. This resulted in relative parameter values of 1.00 for all control plants. The comparison of relative parameter values among the clipping 
66

Table 5. Light-saturated photosynthetic rates ${ }^{*}\left(\mathrm{P}_{2000}\right)$ and quantum efficiencies ${ }^{\star *}(Q E)$ from Smith equations fitted to diurnal gas exchange data

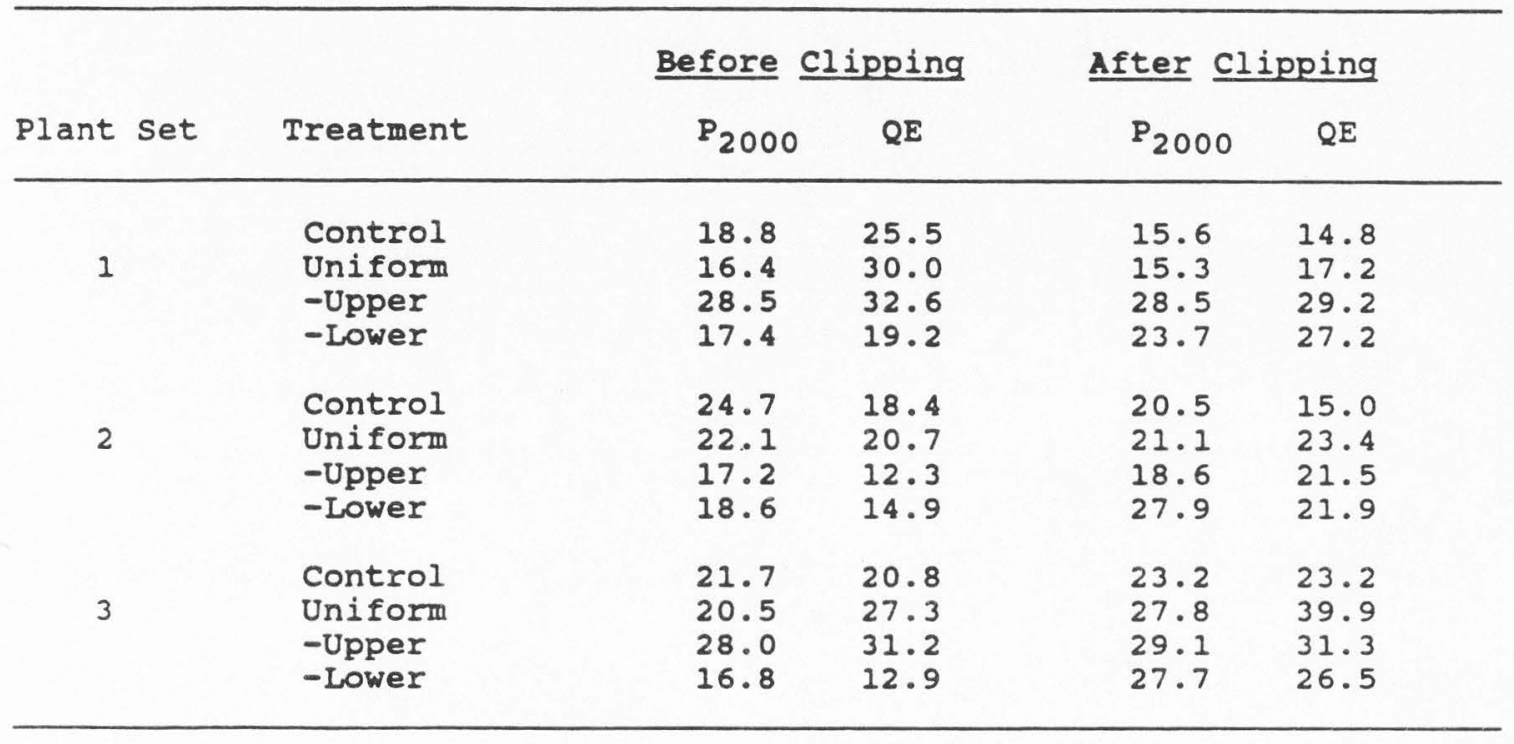

$$
\begin{aligned}
& \text { * umol } \mathrm{CO}_{2} \mathrm{~m}^{-2} \mathrm{~s}^{-1} \\
& \star \text { mol } \mathrm{CO}_{2} \mathrm{~m}^{-2} \mathrm{~s}^{-1} / \mathrm{uE} \mathrm{m}^{-2} \mathrm{~s}^{-1}
\end{aligned}
$$


patterns was done with analysis of variance in a randomized block design (replicate plant sets = blocks). The difference between each clipping treatment and the control plants was evaluated by testing for a significant difference of the treatment mean from 1.0. Mean differences are reported as significant when $\mathrm{P}<0.05$.

\section{Canopy structure}

The distribution of foliage in the tussock canopy was assessed with a fiber-optic point quadrat system. The system and technique are described by caldwell et al. (1983b). In point quadrat sampling, a pin is passed through vegetation at a certain angle and contacts with foliage are recorded in addition to the distance of pin travel from a fixed reference point. Calculations developed by Warren Wilson $(1960,1963)$ allow the estimation of foliage quantity and distribution from these data. The total foliage area of each of the 12 tussocks was determined 2 d before defoliation and 2 d after defoliation by quadrats inclined at 32.5 degrees. The ratio of projected to actual foliage area is least variable over a wide range of foliage inclination angles when quadrats are inclined at 32.5 degrees (Warren Wilson 1960). Projected sunlit foliage area was determined for conditions around solar noon by taking the frequency of initial contacts with green foliage using quadrats inclined at 65 degrees (Caldwell et al. 1983a). 
Light interception

The interception of photosynthetic photon flux (PPF; 400-700 nm) at solar noon was estimated for each tussock before and after defoliation. Light interception was calculated for conditions at solar noon because these correspond to the conditions at which $\mathrm{P}_{2000}$ would be measured. The calculations were done in the following manner. Global shortwave radiation from $400-700 \mathrm{~nm}$ was measured above the tussock canopy with a quantum sensor (Licor Co.). This irradiance was divided into direct and diffuse components for clear sky conditions using a model described by caldwell et al. (1986). Each tussock canopy was divided into 5 horizontal layers, with average foliage inclination angles for each layer taken from the data of Caldwell et al. (1983a). The flux density of direct beam radiation on sunlit foliage of each layer was calculated using Lambert's cosine law with data on average foliage inclination angle and solar zenith angle. These calculations were made for six different foliage azimuth orientations and averaged. The diffuse radiation flux at the top of each layer was measured with a gallium-arsenide phosphide (GaAsP) photodiode (Hamamatsu Co. model G1118) (Gutschick et al. 1985). There is an excellent linear correlation between the response of the GaAsP photodiodes and the output of a quantum sensor over the range of darkness to maximum solar irradiance in the open and under a foliage canopy (Chazdon and Field 1987, Gold, unpublished 
data). This diffuse flux was assumed to be incident on all foliage within the layer below the measurement. The total fluxes for sunlit (direct + diffuse) or shaded (diffuse) foliage were multiplied by the amount of each type of foliage present in the layer and summed to calculate the total PPF interception by each layer. Penumbral effects were ignored in these calculations. The individual layers were summed to calculate the PPF interception by the entire tussock.

The proportion of foliage sunlit or shaded in each layer is required by the calculations described above. This was estimated with two independent methods. The first method used the ratio of projected sunlit foliage area to total foliage area as measured by inclined point quadrats (Caldwell et al. 1983a). The second method used the ratio of sunlit to shaded readings of a GaAsp photodiode passed along a horizontal transect through the center of the tussock. Transects were located at the top of each foliage layer, and readings of photosynthetic photon flux density were recorded every $4 \mathrm{~mm}$. Readings were considered sunlit above $900 \mathrm{uE} \mathrm{m}^{-2} \mathrm{~s}^{-1}$ and shaded below that value. The readings were taken within 1 h of solar noon 2 d before defoliation and 2 d after defoliation. There was very good agreement between the values of tussock light interception calculated with the two different estimates of sunlit and shaded foliage proportions (Fig. 13). Light interception calculated from sunlit and shaded proportions measured with 


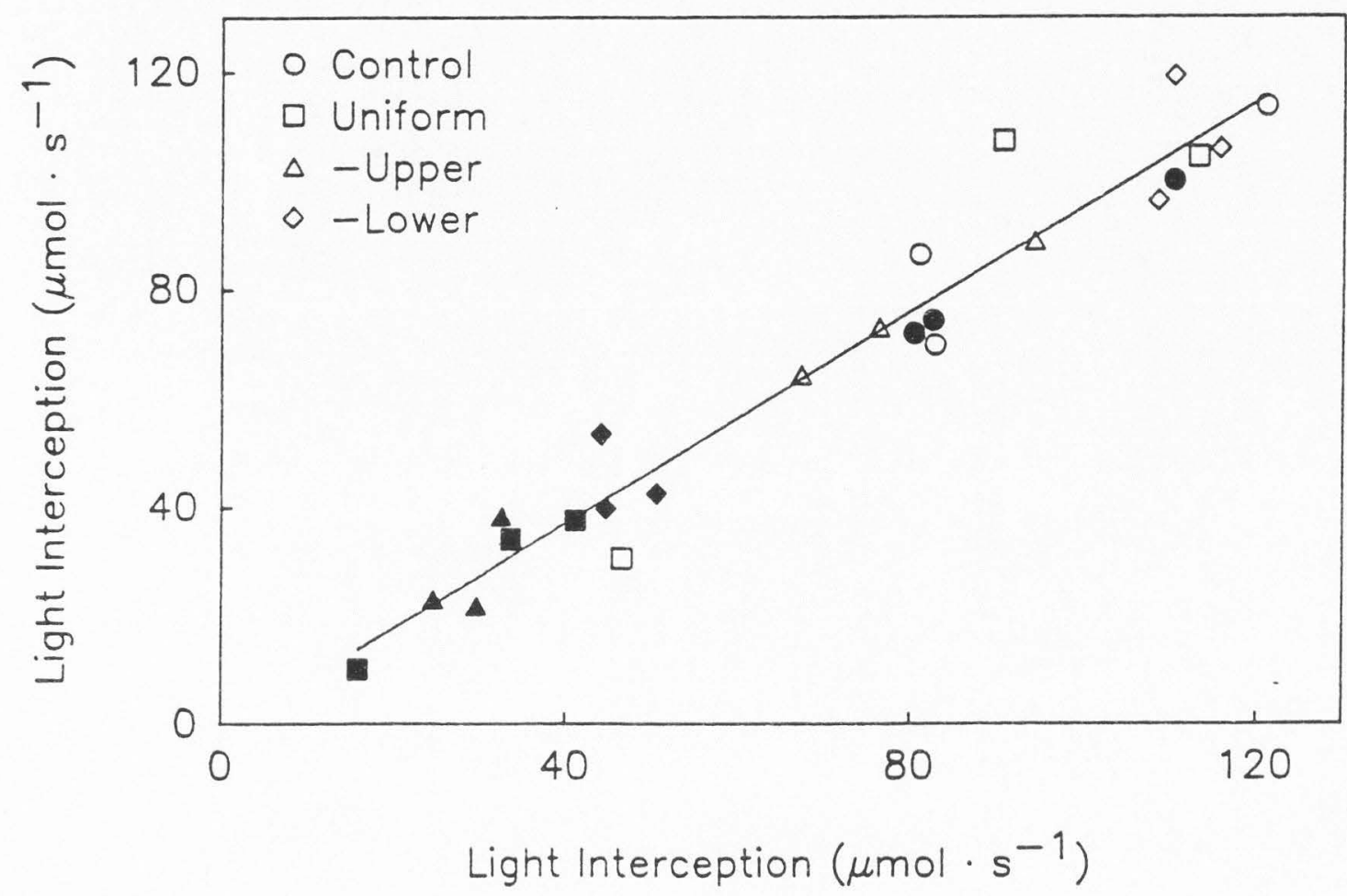

Fig. 13. The correlation between two estimates of tussock light interception calculated using different measures of the proportion of foliage sunlit. The ratio of projected sunlit foliage area to total foliage area, as measured by inclined point quadrats, was used in the calculations for the vertical axis. The fraction of readings fully sunlit as a GaAsP photodiode was passed along horizontal transects through the center of the tussock was used in the calculations for the horizontal axis. Open symbols represent tussocks prior to clipping and closed symbols represent tussocks after clipping $\left(\mathrm{r}^{2}=0.94, \mathrm{P}<.001\right)$. 
point quadrats will be used in the remainder of this chapter.

Foliage age structure

In $\underline{\text { A. }}$ desertor $\underline{\text { um }}$ tussocks, new foliage is produced at the top of each tiller. A maximum of 7 leaves were produced per tiller during the growing season. The lowest green leaf on each tiller following snowmelt (position 1) was designated as the oldest leaf and the leaves at higher vertical positions (2 to 7 ) were sequentially younger. The amount of green foliage area at each position was measured nondestructively on 10 tillers of each tussock (see Chapter II). Foliage area was measured immediately before defoliation and 1, 14, and 28 days after defoliation.

Results

\section{Photosynthetic characteristics}

The maximum photosynthetic rate $\left(\mathrm{P}_{2000}\right)$ and quantum efficiency of tussocks increased significantly following the removal of lower leaf blades (Table 6; Fig. 14). Tussocks from the uniform and -upper clipping patterns exhibited increases in $\mathrm{P}_{2000}$ and quantum efficiency, but these were not significantly different from those of the control plants $\left(P=.07\right.$ and .11 for $\mathrm{P}_{2000 ;} \mathrm{P}=.45$ and .12 for quantum efficiency). However, the integrated daytime $\mathrm{CO}_{2}$ uptake $\left(C E R_{d}\right)$ of uniform and -upper plants increased significantly after defoliation relative to control plants (see chapter III, Fig. 9b). The lack of statistical significance of the 


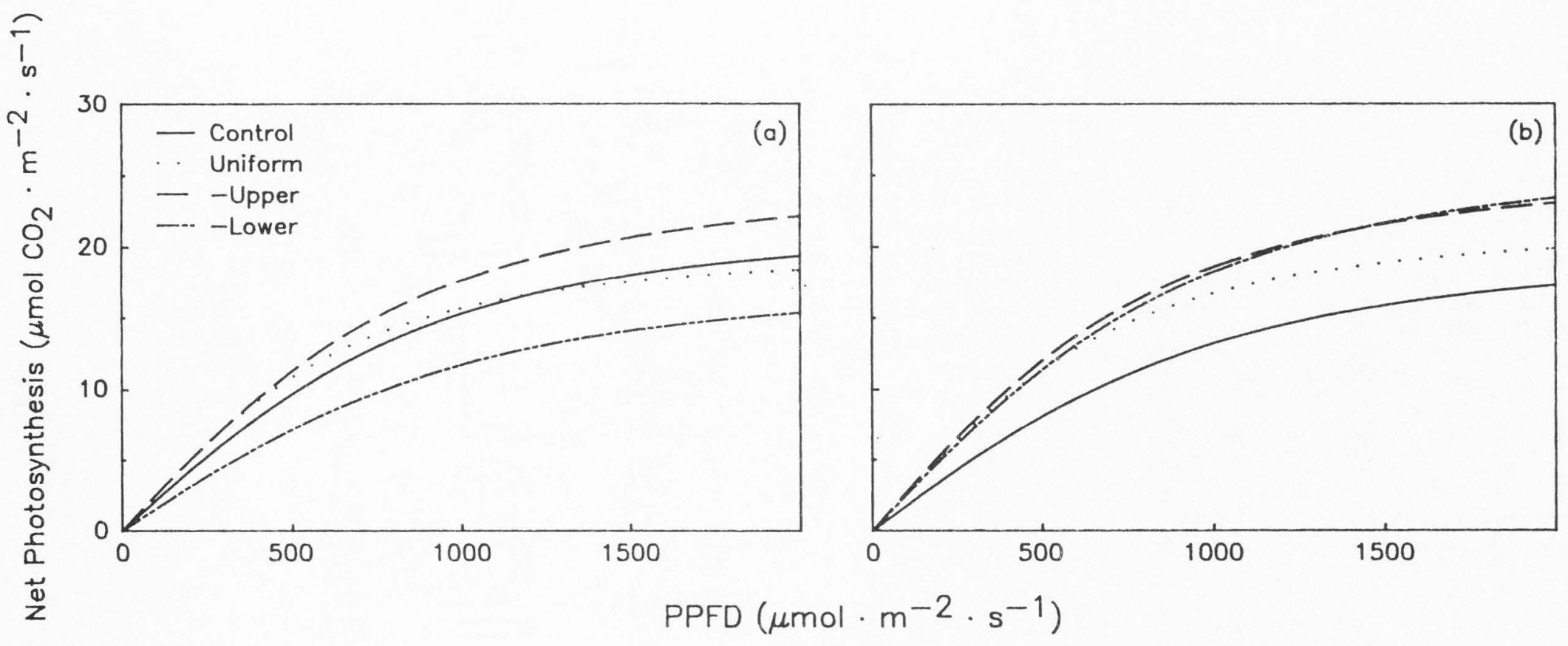

Fig. 14. Net photosynthesis of tussocks (a) before clipping and (b) after clipping as a function of the natural diurnal variation in photosynthetic photon flux density. Each curve is the average of 3 tussocks. The curves are drawn from fitted Smith equations. 
Table 6. Relative changes in light-saturated photosynthesis ${ }^{\star}\left(P_{2000}\right)$ and quantum efficiency ${ }^{*}$ ( $Q E$ ) following defoliation

\begin{tabular}{lll}
\hline Treatment & $P_{2000}$ & QE \\
\hline Control & $1.00 \mathrm{a}$ & $1.00 \mathrm{a}$ \\
Uniform & $1.19 \mathrm{a}$ & $1.23 \mathrm{ab}$ \\
-Upper & $1.16 \mathrm{a}$ & $1.53 \mathrm{ab}$ \\
-Lower & $1.67 \mathrm{~b}$ & $2.03 \mathrm{~b}$ \\
\hline
\end{tabular}

* units for $P_{2 p g O}$ are umol $\mathrm{CO}_{2} \mathrm{~m}^{-2} \mathrm{~s}^{-1}$; units for $\mathrm{QE}$ are nmol $\mathrm{CO}_{2} \mathrm{~m}^{-2} \mathrm{~s}^{2 \mathrm{p} 9 \mathrm{OE}} \mathrm{m}^{-2} \mathrm{~s}^{-1} ;$ different letters indicate means significantly different $(P<.05 ; n=3)$ within each parameter

increases in $\mathrm{P}_{2000}$ after uniform or -upper defoliation was probably due to a small sample size $(n=3)$ and variability in the photosynthetic light response data.

There was a positive linear relationship between the relative change in $\mathrm{P}_{2000}$ (umol $\mathrm{CO}_{2} \mathrm{~m}^{-2} \mathrm{~s}^{-1}$ ) and the relative change in CER $\mathrm{d}$ ( $\mathrm{mol} \mathrm{CO}_{2} \mathrm{~m}^{-2} \mathrm{~d}^{-1}$ ) of tussocks following defoliation (Fig. 15). The predicted relative changes in $\mathrm{P}_{2} 000$ and $\mathrm{CER}_{\mathrm{d}}$ from the regression line are nearly equal (e.g. a doubling of $\mathrm{P}_{2000}$ is associated with a doubling of CER $R_{d}$. Apparently, the integrated daytime carbon gain of these tussocks was well correlated with the instantaneous canopy photosynthetic rate under saturating irradiance. The -lower plants had the greatest relative increases in both $\mathrm{P}_{2000}$ and $\mathrm{CER}_{\mathrm{d}}(50$ - 80 percent). The other clipping patterns resulted in smaller increases of $P_{2000}$ and $C E R_{d}$ relative to control plants $(0-30$ percent $)$. 


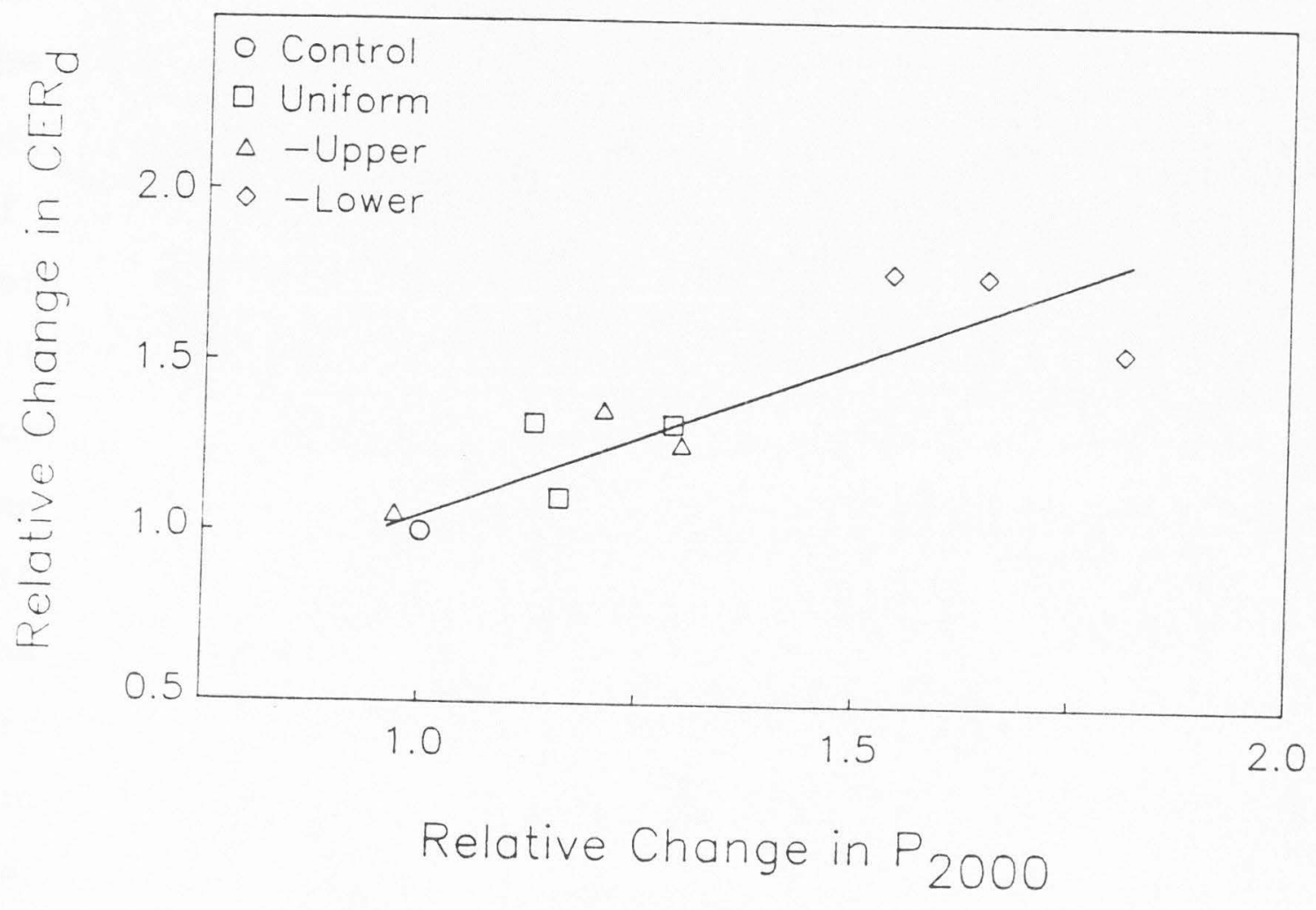

Fig. 15. The relationship between the relative change (postclip/preclip) in $\mathrm{P}_{2} 000$ and the relative change in CER taken during the $24 \mathrm{~h}$ periods immediately before data were defoliation. The relative changes are normalized to the changes of the control plants (see text). 


\section{Canopy structure}

Four days elapsed between the preclipping and postclipping measurements of canopy structure. During that time, control tussocks lost a small amount of foliage low in the canopy through senescence and gained a small amount of foliage high in the canopy (Fig. 16). The vertical pattern of foliage distribution was substantially altered by the defoliation treatments. The removal of upper foliage by either the uniform or -upper clipping resulted in a concentration of foliage from 0 to $15 \mathrm{~cm}$ above the ground. The average inclination of the foliage in these lower layers (55 - 75 degrees) was less than that of foliage higher in the canopy (75 - 85 degrees) (Fig. 16). The -lower clipping greatly reduced the foliage low in the tussock, concentrating the remaining foliage in a layer from 10 to 20 cm above the ground. Thus, immediately following defoliation, canopies of uniform and-upper tussocks were short with lower angle leaves, whereas canopies of -lower tussocks were taller and had more erect leaves.

\section{Light interception}

The proportion of tussock foliage directly illuminated at solar noon varied from 41 to 72 percent prior to defoliation. The change in the proportion of foliage sunlit was analyzed relative to both the preclipping conditions and the change in the associated control plant. Changes in the proportion of foliage sunlit were positively associated with 


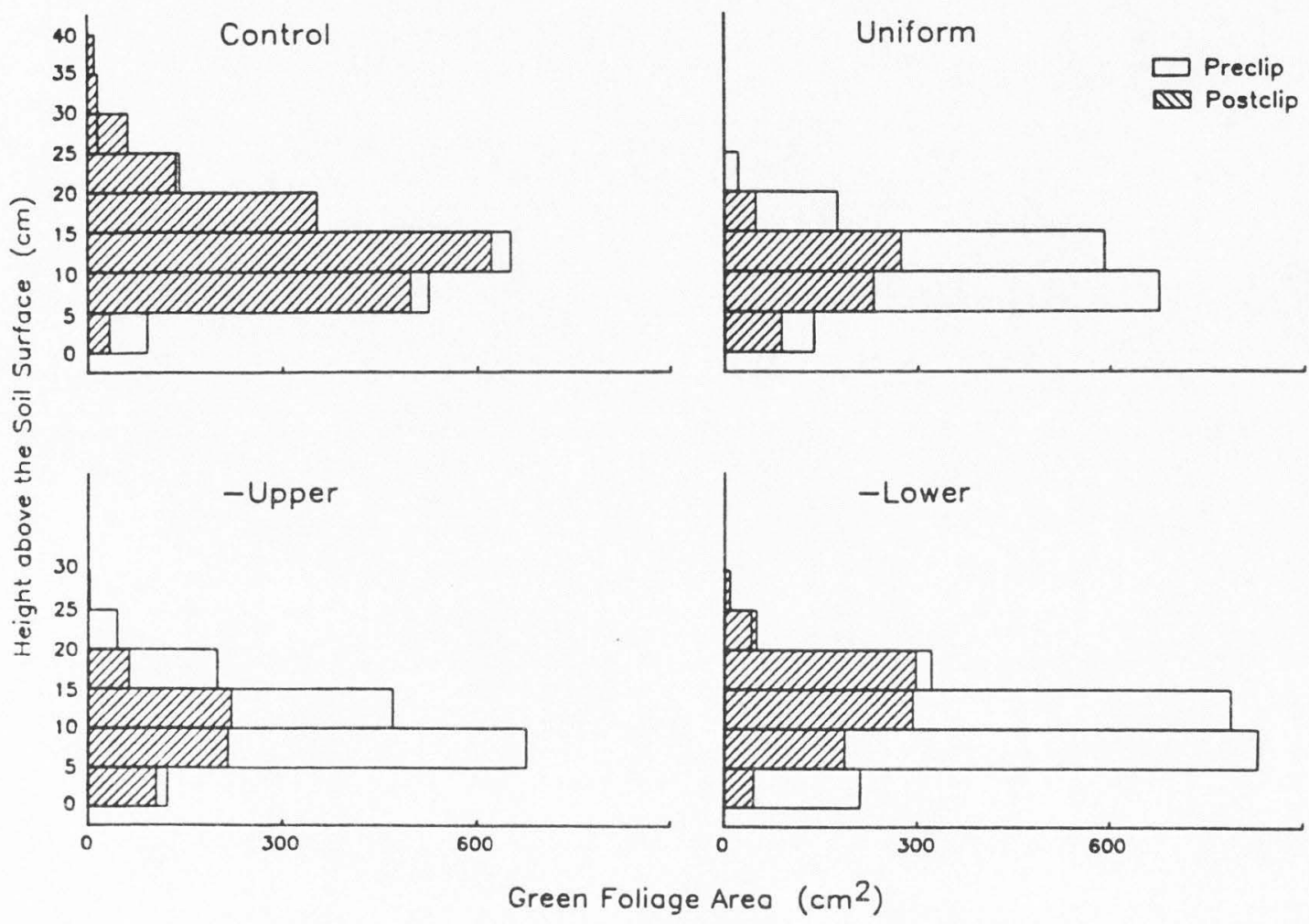

Fig. 16. The vertical distribution of tussock green foliage area in $5 \mathrm{~cm}$ increments from the soil surface. Each treatment is the mean of 3 tussocks. The average foliage inclination angles for $10 \mathrm{~cm}$ incements as measured on $A$. desertorum tussocks by Caldwell et al. (1983a) are shown. Preclipping and postclipping measurements were taken 72 to 96 hours apart. New growth at the top of the canopy over that time period is apparent in the control and -lower plants. Foliage loss at the bottom of control tussocks over that time period can also be seen. 
changes in $\mathrm{P}_{2000}$ (Fig. 17). The fractional changes in percent foliage sunlit are nearly equivalent to the fractional changes in $\mathrm{P}_{2000}$ along the linear relationship (slope $=0.89)$. Eight of the nine clipped plants showed increases in the proportion of foliage sunlit following clipping relative to the control plants. The -lower plants had the largest increases in both proportion of foliage sunlit (50 to 80 percent) and $\mathrm{P}_{2000^{\circ}}$ The uniform and -upper defoliation patterns caused smaller increases in $\mathrm{P}_{2000}$ and the proportion of foliage sunlit ( 0 to 40 percent).

Even though defoliation changed the proportion of foliage which was sunlit, it did not affect the total amount of light intercepted by a plant with a given amount of foliage area. The positive linear relationship between tussock green foliage area and light interception remained the same before and after defoliation (Fig. 18). Following defoliation, -lower plants intercepted more light than uniform or -upper plants. However, this was due to the greater amount of foliage area of the -lower tussocks, rather than the differences in canopy structure among these treatments.

\section{Foliage age structure}

Prior to clipping, the relative amount of foliage area at different leaf positions along the tiller was similar for all treatments (Fig. 19). The proportion of foliage area at different leaf positions is representative of the relative age structure of foliage at each date. Comparisons cannot 


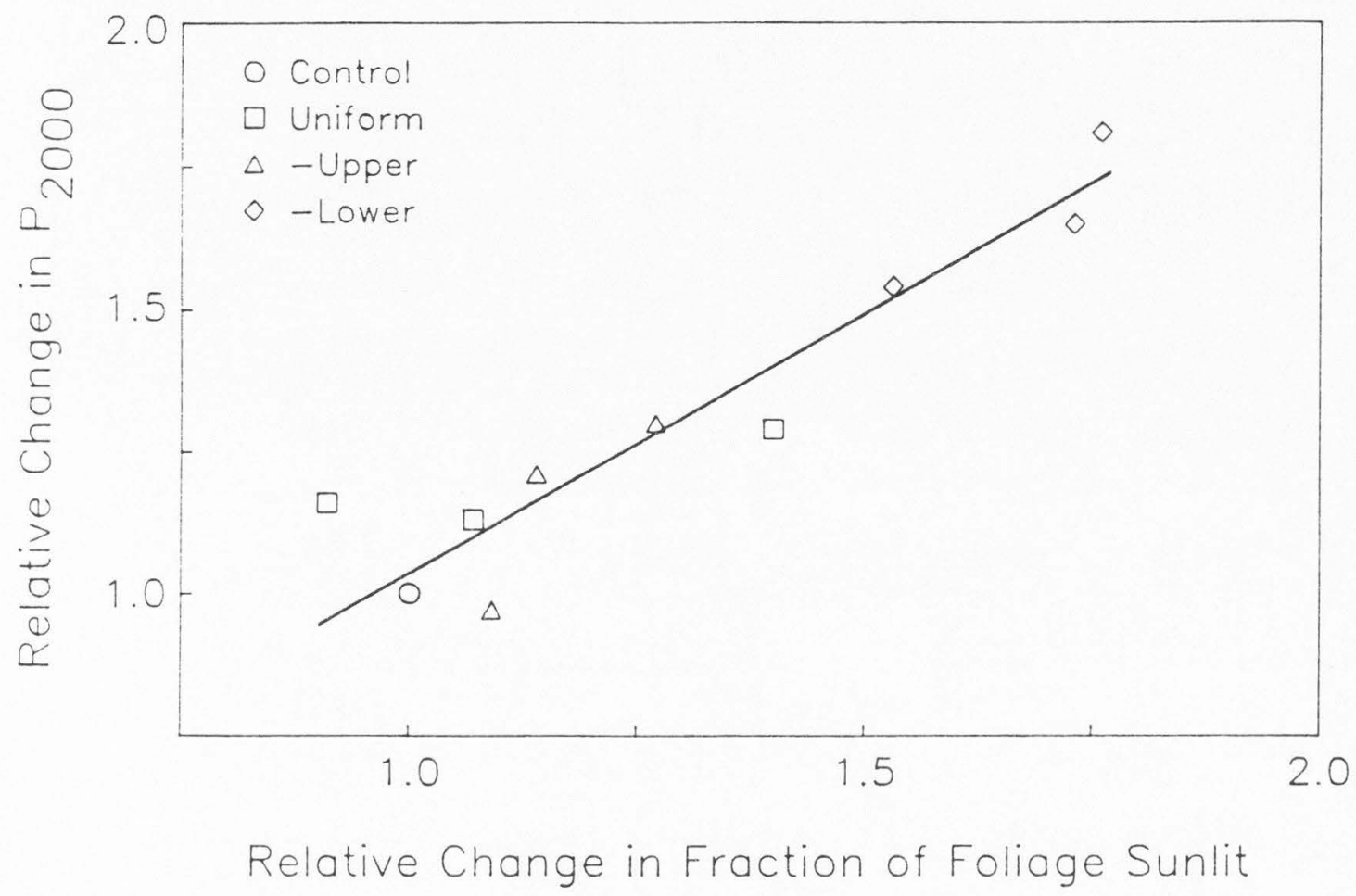

Fig. 17. The relationship between the relative change in the proportion of tussock foliage directly illuminated and the relative change in $\mathrm{P}_{2000}$ after defoliation. The relative changes of all tussocks are normalized to the relative changes of the control plants (see text). All data was taken within $48 \mathrm{~h}$ before and after defoliation $\left(\mathrm{r}^{2}=\right.$ $0.89, \mathrm{P}<.001$ ). 


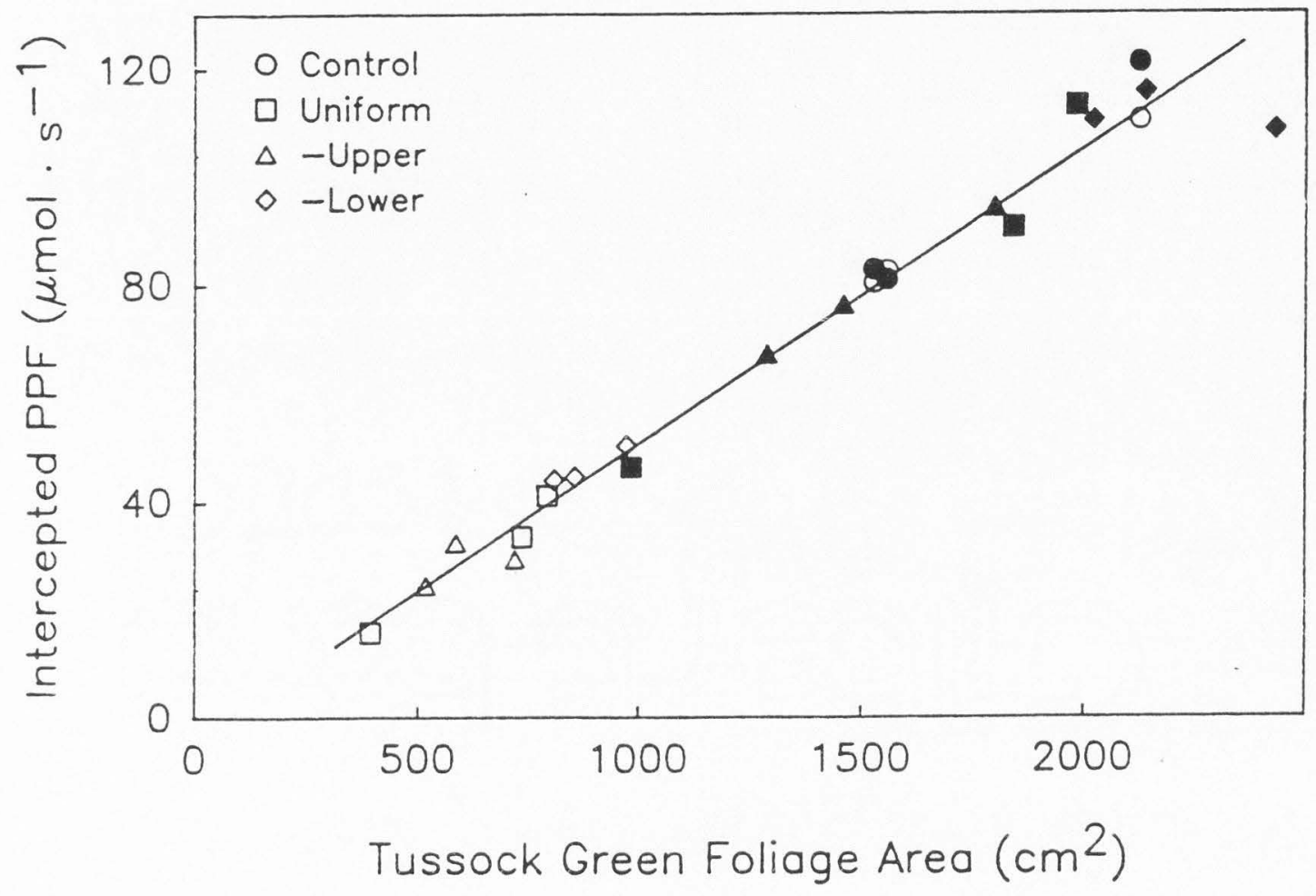

Fig. 18. The relationship between the green foliage area of a tussock and the calculated interception of photosynthetic photon flux by the tussock at solar noon. closed symbols represent tussocks prior to defoliation and open symbols represent tussocks after defoliation $\left(r^{2}=0.97, P<.001\right)$. 


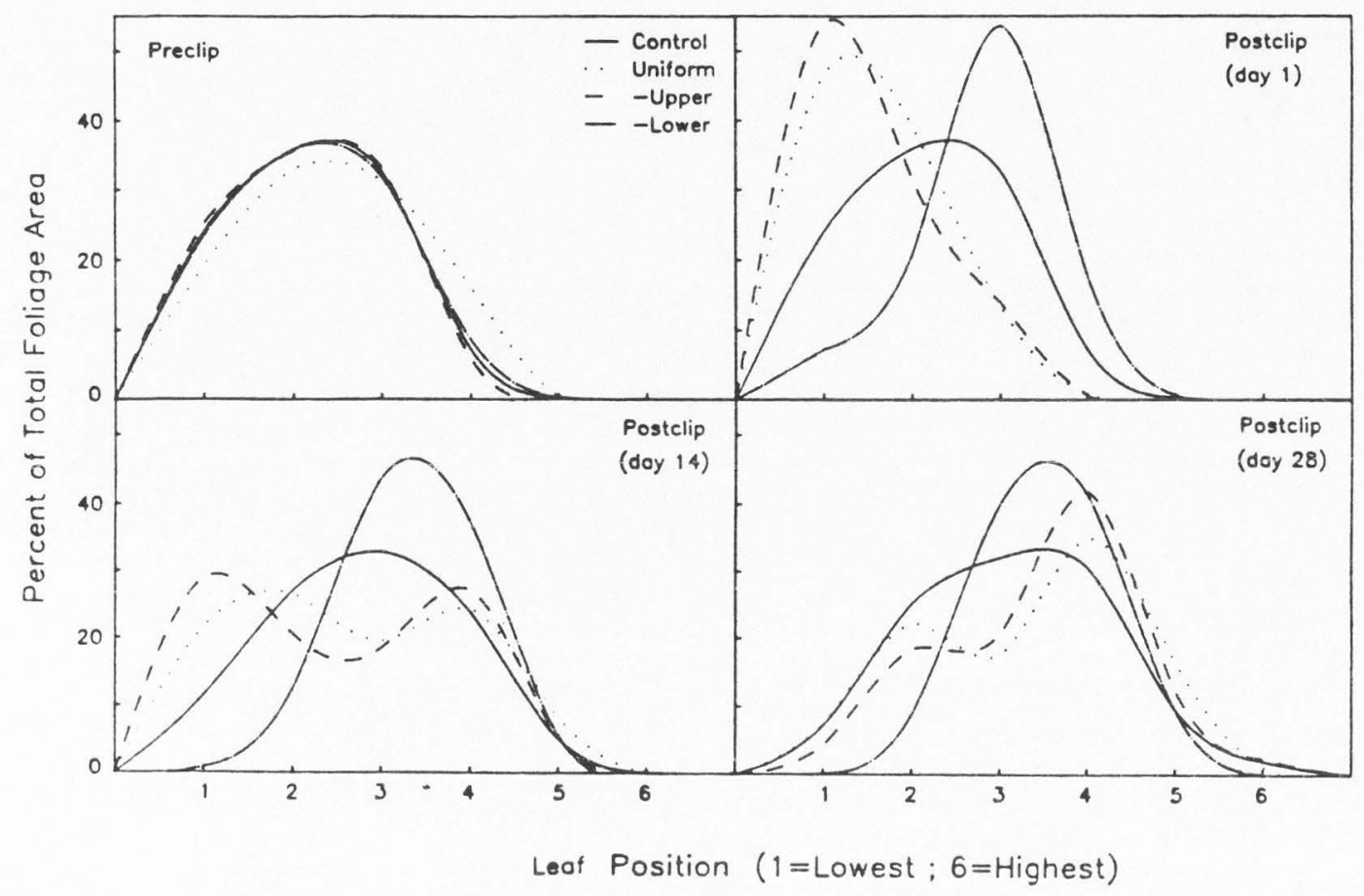

Fig. 19. The relative amount of tussock foliage area at different leaf positions prior to clipping and 1, 14, and 28 d after clipping. Each curve is the average of 3 tussocks. 
be made between dates because the absolute age of foliage at each position changes over the intervening period between measurements. The differences among treatments in foliage age structure immediately following defoliation were not surprising. Removal of foliage high in the tussock canopy, by either the uniform or -upper clipping pattern, shifted the age structure toward older foliage. In contrast, the -lower defoliation shifted the age structure toward younger foliage. The relative amounts of foliage in different positions of the -lower plants changed little over the first $28 \mathrm{~d}$ of regrowth, whereas the uniform and -upper plants showed a relatively rapid shift toward foliage higher on the tillers (younger). After 28 d of regrowth, all of the clipped plants had proportionally less older foliage than the control plants. Although differences in foliage age structure among the clipped plants were reduced by regrowth, they remained substantial 28 d following clipping (Fig. 19).

Discussion

The compensatory increases in instantaneous lightsaturated photosynthesis following clipping were clearly related to increases in integrated daily $\mathrm{CO}_{2}$ uptake (Chapter II) and regrowth rates (Chapter II). Compensatory photosynthetic increases following defoliation have been demonstrated for single leaves of a variety of species (McNaughton 1983), including Agropyron desertorum (Nowak and Caldwell 1984). Nowak and Caldwell (1984) reported an average increase of 27 percent in single-leaf photosynthesis 
of A. desertoruㅡ after uniform clipping. In this study, whole-tussock photosynthesis increased 19 percent following uniform defoliation (Table 6). Such a close correspondence between changes in single-leaf and whole-plant rates may be fortuitous. The relationship between single-leaf responses and whole-plant responses can be highly complex (Bunce 1986). Ludlow and Charles-Edwards (1980) found little relationship between calculated photosynthetic characteristics of single leaves and measured photosynthesis of entire swards in grass/legume mixtures following defoliation. Instead, changes in canopy structure and light interception were of primary importance for whole-canopy gas exchange after defoliation (Ludlow and Charles-Edwards 1980). In this study, plants which had lower leaf blades removed showed much larger increases in whole-plant photosynthetic rates (67 \%) than the uniform and -upper plants. Descriptions of an average single leaf response to defoliation are clearly not sufficient for an understanding of whole tussock response to different defoliation patterns. Even in many intact plants, the photosynthetic rates of a single leaf can bear little relationship to whole plant photosynthesis (Acock et al. 1978) and growth (Gifford and Jenkins 1982, Bunce 1986).

With the recognition that foliage of different ages have different photosynthetic capabilities, many authors have suggested that changes in foliage age structure caused by defoliation could have important effects on plant 
regrowth (Janzen 1979, Dirzo 1984, Hartnett and Bazazz 1986). The results of this study support that hypothesis. The age structure of foliage on these tussocks was altered in ways that were consistent with the observed changes in photosynthesis and regrowth. Younger leaves of $\underline{A}$. desertorum have greater light-saturated photosynthetic rates and higher quantum efficiencies than older leaves (Nowak and Caldwell 1986). Light-saturated photosynthesis and quantum efficiency increased more in -lower plants, which had younger foliage remaining after defoliation (Fig. 19). Research on crops (e.g. Brown et al. 1966) and conifers (Mckey 1979) has also shown reduced effects of defoliation on growth when older foliage was removed. Without extensive data on the photosynthetic light responses of all age classes of foliage, it is difficult to quantitatively assess what the observed changes in age structure (Fig. 19) might mean for whole-plant photosynthetic rates. However, it is unlikely that changes in age structure alone would have accounted for the differential photosynthetic responses of the tussocks. Caldwell et al. (1983a) have shown that light attentuation is rapid within these dense tussocks at this time of year and there is considerable shaded foliage. Defoliation would certainly affect tussock canopy structure, and consequently alter light interception and the fraction of foliage directly illuminated, which are also important factors in canopy photosynthesis (Monsi et al. 1973).

Changes in the physical structure of the tussock 
canopies and their subsequent effects on the fraction of foliage directly lit within the tussocks were also consistent with the observed changes in canopy photosynthesis. After the removal of lower leaf blades, the remaining canopy foliage was more steeply inclined than after removal of upper canopy foliage (Fig. 16). Dense plant canopies with erect foliage have commonly been found to be more productive than similar canopies with more prostrate foliage (Rhodes 1969, 1971, Monsi et al. 1973, Sugiyama et al. 1985, woledge and Parsons 1986). This is usually attributed to a decreased rate of light attenuation with depth in a more erect canopy. Thus, in an erect canopy fewer leaves would be illuminated above the point of photosynthetic light saturation and a smaller proportion of leaves would be shaded. These advantages of erect foliage for canopy photosynthesis are greatest for dense canopies, such as $\underline{A}$. desertorum, at high solar zenith angles (Jones 1983). The change in canopy structure of the -lower tussocks to more erect foliage was associated with the largest decreases in the proportion of foliage shaded among all clipped plants (Fig. 17). These changes in canopy structure simply altered the proportion of foliage directly Iit, but not the total amount of light intercepted. A reduction in the proportion of foliage shaded in these dense tussocks could be of substantial value to tussock $\mathrm{CO}_{2}$ fixation. Caldwell et al. (1983a) showed that over half of the foliage on a typical A. desertorum tussock is shaded at 
solar noon at this time of year. The photosynthetic rate per unit leaf area of shaded $\underline{A}$. desertor $\underline{\text { dex }}$ foliage is considerably reduced compared to fully illuminated foliage, even for older foliage (Caldwell et al. 1983a, Nowak and Caldwell 1986). Reducing this shaded fraction could substantially increase $\mathrm{CO}_{2}$ uptake per unit leaf area and specific growth rates (see Chapter II).

The spatial patterns of defoliation that occur within a grass tussock in nature can be highly variable. Large grazers generally remove younger, upper foliage, but not all tillers within a tussock are always defoliated to the same degree. In such instances, the degree of resource sharing and competition among tillers could have a major effect on plant regrowth (Archer and Detling 1984). Insect herbivores are usually more selective. Hansen (1987) found that Irbisia pacifica (Hemiptera: Miridae) concentrates its feeding on intermediate-aged leaves of $\underline{A}$. desertorum. Other insect herbivores may show preferences for certain foliage based upon particular foliage qualities or the location of preferred microsites within the canopy for feeding (e.g. Joern 1982), or escape from predators and parasites (Faeth 1985).

The development of empirical relationships between all possible patterns of defoliation and their effects on regrowth is probably not tractable. Instead, the impacts of spatial patterns of defoliation on major factors that constrain plant regrowth must be elucidated. This has been 
the focus of these studies. The extremely different clipping patterns used in these experiments had substantially different effects on plant regrowth (Chapter II). The impacts on regrowth directly corresponded with effects on integrated daytime tussock carbon gain (Chapter III), which was correlated to changes in instantaneous rates of tussock photosynthesis at full sunlight. The defoliation patterns affected both canopy physical structure and foliage age structure in ways which could have been responsible for the observed changes in photosynthesis. In all likelihood, the responses of tussock photosynthesis were a result of a complex interaction of the changes in foliage age structure and changes in the proportion of tussock foliage directly illuminated. Hence, the effect of herbivore selectivity on the age of foliage removed and changes in the canopy light microclimate would likely have quite important implications for the regrowth of tussock grasses following spring defoliation. 
CHAPTER V

INTEGRATION

Introduction

This final chapter will place the results from the clipping experiments in the preceding chapters into the context of actual herbivory. First, I will discuss the relationship of clipping studies to actual herbivory. I will examine how differences between clipping and herbivory might affect the extrapolation of these results to situations involving defoliation by natural herbivores. secondly, I will consider the general patterns of defoliation inflicted on grass tussocks by the principal herbivores of $\underline{A}$. desertorum in the Intermountain region. The effects of those patterns on regrowth are discussed on the basis of the results from the previous chapters. Thirdly, the selection of foliage within a plant, which was the focus of this research, will be placed into the context of the many spatial scales at which foliage selection can take place (e.g. among species, among individual plants, etc.). The implications of herbivore selectivity at these levels for plant populations and communities, as well as individual plants will also be examined. Finally, I will discuss the implications of compensatory photosynthesis at the single-leaf and whole-plant levels for foliage regrowth. I will examine the process of scaling up from increases in single-leaf photosynthesis to whole-plant photosynthesis, 
and finally to the production of new foliage. The appropriateness of measurements of single-leaf photosynthesis for examining the effects of different spatial patterns of defoliation is also considered.

Artificial defoliation and actual herbivory

The experiments described in the previous chapters were designed to examine plant response to different spatial patterns of defoliation. In order to inflict replicable patterns of defoliation at the same defoliation intensity, the tussocks were clipped with scissors. Such clipping experiments differ from actual herbivory in a number of ways that merit discussion.

The physical manner of foliage removal can differ between herbivory and artificial clipping. Large grazers, particularly domestic cattle, defoliate grasses with a tearing motion rather than a clipping action. The pulling force exerted on plants by the tearing motion of such grazers may affect the remaining plant tissues, or even pull the plant out of the soil. Feeding by specialized folivorous insects can also be quite different from clipping. These insects may remove cellular contents by sucking, or remove certain leaf tissues by rasping, chewing, mining, etc. (Dyer et al. 1982, Crawley 1983). In nature, the effects of different spatial patterns of defoliation may be confounded with the physical manner of foliage removal. The importance of interactions between the physical manner 
of foliage removal and the spatial pattern of defoliation has not been investigated.

There has been speculation that chemical contents of herbivore saliva may stimulate plant regrowth (Dyer and Bokhari 1976, Owen and wiegert 1981). This appeared plausible because of compounds found in saliva that have been shown to increase plant growth in the laboratory (Stowe and Hudson 1969, Reardon et al. 1974, Geuns 1978). However, subsequent work has found no effect of either bison saliva (Detling et al. 1980a) or grasshopper saliva (Detling and Dyer 1981) on photosynthesis and regrowth of Bou gracilis. Therefore, the limited experimental evidence does not support a major role for salivary chemicals in the effect of herbivores on grasses.

Trampling by large grazers can have important effects on plants which are usually not a part of clipping experiments. Salihi and Norton (1987) found that the mortality of Agropyron desertorum seedlings was much higher in pastures grazed by livestock ( $91 \%$ ) than in ungrazed pastures (55\%). They attributed the higher mortality in grazed pastures to livestock trampling of the seedlings. Grazing livestock generally avoid trampling established grass tussocks (Balph and Malechek 1985). Trampling of bare soil may indirectly affect plant growth by reducing the infiltration rate of precipitation into the soil (Warren et al. 1986). The importance of the spatial pattern of defoliation for plant growth and survival would be reduced 
in situations where substantial trampling takes place.

Clipping experiments also do not simulate the effects of herbivores on nutrient cycling and nutrient availability to plants. In a clipping experiment, the foliage cut off of a plant (and the nutrients contained in that foliage) are removed, whereas herbivores return some of these nutrients in the form of feces and urine. The return of nutrients by large herbivores can be patchy, but can have profound effects on plants in the near vicinity (e.g. Marsh and Campling 1970). Herbivores can significantly alter the distribution of nutrients over an area by consuming foliage in one place and depositing wastes in other places (Crawley 1983). This spatial transfer of nutrients can influence plant community structure (e.g. Batzli et al. 1980). The plants in my clipping studies did not have the benefit of herbivore-deposited nutrients, but the actual waste deposition by herbivores near particular grazed plants would be highly variable and difficult to predict.

Few direct comparisons between clipping and herbivore defoliation have been made (Capinera and Roltsch 1980 , Hammond and Pedigo 1981, Ostlie and Pedigo 1984, Walmsley et al. 1987). Laboratory studies have shown that the growth of some grasses is different following artificial clipping than after actual grasshopper grazing (Capinera and Roltsch 1980, Walmsley et al. 1987). In these experiments, plant growth was reduced less following light grazing by grasshoppers than following light clipping. Heavy grasshopper grazing 
reduced regrowth more than heavy clipping. The mechanisms involved with these responses were not studied.

Although it is clear that clipping cannot exactly mimic grazing, the objective of my research was to specifically investigate the effects of different foliage removal patterns. The controlled field studies in the preceding chapters demonstrate that the spatial pattern of foliage removal can affect regrowth under a variety of circumstances.

Herbivores and spatial patterns of defoliation of Agropyron desertorum

The clipping treatments used in these experiments represented extremely different spatial patterns of defoliation which could be inflicted on $\underline{A}$. desesertor $\underline{\text { deu }}$ tussocks by actual herbivores. There are a variety of herbivores that defoliate $\underline{A}$. desertorum tussocks throughout the growing season in the Intermountain region.

The most common large grazers of $\underline{A}$. desertorum in the Intermountain region are domestic livestock. Livestock remove tussock foliage from above, sometimes resulting in a defoliation pattern similar to the uniform clipping used in these experiments. Frequently, however, only some of the tillers on the tussock will be defoliated, while others are left intact ("partial defoliation") (Norton and Johnson 1983). A partial defoliation could differ substantially from a uniform defoliation in its effect on canopy light microclimate, foliage age structure, and subsequent tussock 
regrowth.

The regrowth of defoliated tillers on a partially defoliated tussock could be supported by intact tillers through the translocation of current assimilates or stored reserves (e.g. Marshall and Sagar 1965, Gifford and Marshall 1973, welker et al. 1985). However, Archer and Detling (1984) concluded that competition for resources between defoliated and nondefoliated tillers overshadowed any beneficial effects of resource sharing among tillers in two graminoid species they studied. For $\underline{A}$. desertorum tussocks, Olson and Richards (1988) reported that the annual replacement of defoliated tillers was the same if neighboring tillers within the tussock were intact than if those neighboring tillers were defoliated. This suggests that interactions among tillers may be of only minor concern in the response of $\underline{A}$. desertorum tussocks to defoliation.

Large grazers can remove apical meristems from $\underline{A}$. desesertorum after culm elevation in the late spring. The removal of these meristems can substantially reduce the rate of regrowth (Briske 1986, Olson and Richards 1988). Insect herbivores, however, generally leave apical meristems intact while feeding. Thus, the influence of defoliation by large grazers on $\underline{A}$. desertorum regrowth may be very different than that of insect herbivores because of effects on active apical meristems. This is reflected by the large differences in regrowth rates following the -upper and uniform clipping treatments in late May (Fig. 5). 
Two of the principal types of insect herbivores of $\underline{A}$. desertorum are grasshoppers (Orthoptera) and sucking grass bugs of the genera Labops and Irbisia (Hemiptera: Miridae). These insects feed primarily on leaf blades rather than leaf sheaths of tussock grasses ( $J$ Hansen pers. comm.). The clipping patterns used in my experiments that most closely resemble these types of defoliation patterns are the upper and lower leaf-blade-removal treatments.

Grasshopper and grass bug populations both fluctuate greatly from year-to-year. At high densities, grasshoppers or grass bugs can have a large impact on the vegetation of semi-arid rangelands (Todd and Kamm 1974, Blocker 1977, Hewitt 1977, Haws 1978). These insect herbivores can be quite selective in the plant parts they choose for consumption. For example, Irbisia pacifica preferentially feeds on intermediate-aged leaves of $\underline{A}$. dese $\underline{\text { erton }}$ rum, which occur in the middle of the tussock canopy (Hansen 1987). From the results of my experiments, it is likely that midMay removal of middle (or lower) canopy foliage by grass bugs or grasshopppers would be less detrimental to tussock regrowth than the removal of foliage in the upper portion of the tussock canopy by large grazers (compare uniform and - upper treatments in Fig. 1). Prior to culm elongation, selective feeding by insects on upper canopy foliage would probably have the same effect as the removal of the same amount of foliage by a large grazer (note the similarity of growth responses following uniform and-upper treatments in 
Fig. 1).

other characteristics of defoliation may complicate the extrapolation of my experimental results to the regrowth of

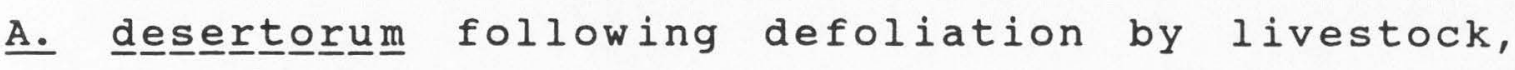
grasshoppers, or grass bugs (see previous section in this chapter). For instance, some aspects of grass bug damage to A. desertorum tussocks are not represented by the leaf-blade clipping treatments in my experiments. Grass bugs remove the contents of leaf mesophyll cells and leave the vascular and structural components of the leaf intact. This may have quite a different effect on plant regrowth than the simple removal of leaf tissue (e.g. these clipping experiments). Large areas of damaged leaf tissue could provide avenues for water loss. Foliage damage by other sucking insects (mites) has been shown to affect leaf transpiration rates (Hammond and Pedigo 1981, DeAngelis et al. 1982, ostlie and Pedigo 1984). The canopy light microclimate (quality and quantity) could also be affected differently by the presence of damaged leaves than by the removal of that leaf tissue from the canopy. The effects of defoliation by sucking insects on canopy light microclimate have not been studied.

Although the intensity of belowground herbivory on $\underline{A}$. desertorum in the Intermountain region may be small (Allen, unpublished data), belowground invertebrates, such as phytophagous nematodes, are often regarded as major consumers of grassland primary production (Blocker 1977 , Dyer et al. 1982). In a pot experiment, the presence of 
nematodes substantially reduced the biomass production of Bouteloua gracilis (Stanton 1983). The photosynthesis and growth of B. gracilis have also been reduced by clipping the roots of plants in hydroponic culture (Detling et al. 1980b). A high intensity of belowground defoliation may reduce the influence of the spatial pattern of aboveground defoliation on the regrowth of $\underline{A}$. desertorum.

Spatial scales of herbivore selectivity

The selection of foliage for consumption by an herbivore can occur at a number of spatial scales. On a large scale, most herbivores display selectivity for certain habitats. The selection of a habitat can be based on many factors in addition to the food resource (e.g. abiotic conditions, exposure to predators, etc.) (Crawley 1983). Within a habitat or foraging area, herbivores usually do not graze individual plants at random (Harper 1977, Norton and Johnson 1986). Certain plant species are preferred over others. On a finer scale, there can also be selection among individuals of the same species (Norton and Johnson 1983, Wambolt et al. 1987, Whitfield et al. 1985) and among parts within a plant (Janzen 1979). Insect herbivores, in particular, are usually quite selective about which plant parts they consume (Hodkinson and Hughes 1982) and where they oviposit within a plant (e.g. Farrar and Bradley 1985, Walker and Aitken 1985). My research focused on the selection of plant parts within a single plant and the 
effect of this selection on that individual plant. This section discusses the influence of other spatial scales of herbivore selectivity on individual plants, populations, and communities.

The selection of some plant species for consumption over others can affect the composition of plant species within a community (crawley 1983). The growth and persistence of preferred species in the community can be directly reduced by defoliation. Additionally, the competitive ability of preferred species may be reduced by foliage removal (Bentley and whittaker 1979, Hodkinson and Hughes 1982, Caldwell et al. 1987). The presence of undefoliated neighbors has been shown to reduce the regrowth of tussock grasses such as Agropyron spicatum (Mueggler 1972) and the annual replacement of defoliated tillers on $\underline{A}$. desertorum tussocks (Olson 1986).

The exclusion of herbivores from a plant community often leads to changes in the species composition of that community (e.g. McNaughton 1979b, Lubchenco 1978, Batzli et al. 1980, Austin et al. 1986, Gibson et al. 1987). These changes in community composition could be due, in part, to alterations in competitive interactions among plant species following herbivore removal.

within a plant population, certain individuals may be selected for consumption, while others are left intact. Factors such as location and cover (Crawley 1983, Lincoln and Mooney 1984), nutritional quality (Zahorik and Haupt 
1977), and secondary chemistry (Yabann et al. 1987) have been correlated with the selection of individual plants. Norton and Johnson (1983) observed that certain individuals of an $\underline{A}$. desertor $\underline{\text { de }}$ m population were left untouched by grazing livestock while others were repeatedly defoliated. In such a situation, the genotype of ungrazed individuals would probably increase in frequency within the population if defoliation is so intense as to have a negative effect on fecundity and survival (Crawley 1983). For example, grazing by slugs was shown to affect the relative proportion of Trifolium repens plants within a population that contain herbivore-deterrent chemicals (Dirzo and Harper 1982).

Herbivores rarely consume the entire plant, but instead, select certain parts for consumption. The selection of plant parts often corresponds with aspects of foliage quality and physical availability. The distribution of secondary metabolites within a plant can often be negatively correlated with the choice of parts for consumption (Mckey 1979, Bryant and Kuropat 1980, Provenza and Malechek 1984). Although grasses lack the carbon and nitrogen-based secondary compounds typically considered to deter herbivores, the silica found in some graminoid leaves may discourage feeding by some herbivores (MCNaughton et al. 1985). In shrubs, the presence of physical deterrents, such as spines or trichomes, can also affect the pattern of foliage removal from a plant (Crawley 1983). Foliage selection by insect herbivores may also be influenced by the 
physical location within the plant canopy, which can affect exposure to predators, parasites and abiotic factors (Crawley 1983, Thompson 1983).

Herbivore selectivity within an individual plant can have implications for plant growth and reproduction (Dirzo 1984). The removal of reproductive structures by an herbivore generally reduces plant fecundity (Harper 1977, Janzen 1979), although Paige and Whitham (1987) have recently presented some evidence to the contrary for Ipoㅡ으노오 aggregata. The effect of removing different vegetative plant parts has been the focus of the research reported in the preceding chapters. The results from these studies (Chapter II), as well as other studies (e.g. Kulman 1965, Dirzo 1984, Mendoza et al. 1987) demonstrate that removal of some vegetative parts affects plant growth more than the removal of others.

Many folivorous insects selectively feed within a leaf, consuming certain tissue or cell types while rejecting others. For instance, leaf miners consume leaf mesophyll tissue and leave behind epidermis and vasculature (Kimmerer and potter 1987). Selection among tissues within a plant part might influence plant response to defoliation but this has not been studied directly. Even without selection for different tissues, the spatial pattern of defoliation within a plant part can influence plant response. Detling et al. (1979) found that net photosynthesis of a grass leaf blade responded differently to defoliation if the blade tip was 
removed than if the same amount of tissue was removed near the base of the blade.

Compensatory photosynthesis : problems of scale

Differences between plants in single-leaf compensatory photosynthesis do not always correspond to differences in the rate of foliage regrowth (Detling and Painter 1983, Nowak and Caldwell 1984). This parallels the general difficulty found in correlating instantaneous rates of single leaf $\mathrm{CO}_{2}$ exchange with growth rates of intact plants (Gifford and Jenkins 1982, Bunce 1986). In order for increased single-leaf photosynthesis to result in increased foliage production, changes in instantaneous single-leaf rates must be expressed as changes in whole-plant daily carbon gain. Additionally, the expression of increased carbon gain as increased foliage regrowth can be complicated by several factors which constrain the production of new foliage. In this section, I discuss the complications involved when scaling up from single-leaf compensatory photosynthesis to whole-plant foliage regrowth.

The expression of instantaneous single-leaf compensatory photosynthesis at the whole-plant level is affected by canopy structure, which influences canopy microclimate and light interception (Monsi et al. 1973). For example, the differential regrowth of two Agropyron smithii populations with similar single-leaf photosynthetic characteristics was probably a result of differences in 
canopy structure and light interception (Detling and Painter 1983). Changes in the age structure of foliage can also influence the expression of single-leaf compensatory photosynthesis as whole-plant photosynthesis. Age may affect the initial photosynthetic ability (Mooney and Gulmon 1982) and the compensatory response (Nowak and Caldwell 1984) of each foliage element. The proportion of heterotrophic to autotrophic tissue of the plant may also affect the expression of single-leaf compensatory photosynthesis at the canopy level.

The relationship between instantaneous rates of wholecanopy photosynthesis and $24-\mathrm{h}$ net carbon gain can also be affected by canopy physical structure and the age structure of plant parts. Canopy structure can affect light interception throughout the range of daily solar zenith angles (Monsi et al. 1973). The age structure of foliage can influence the response of canopy photosynthesis to natural variations in solar irradiance (Chapter IV).

changes in net daily carbon gain can be directly reflected in changes in foliage production only when the production of new foliage is limited by the availability of carbon. other limitations to foliage production, such as morphological constraints (Briske 1986, Richards and Caldwell 1985, watson and Casper 1984), mineral nutrient and water deficits (Fitter and Hay 1981), or air and soil temperatures (e.g. Koerner and Woodward 1987) can sometimes be of overriding importance. The use of carbon storage 
pools and the allocation patterns of carbon within the plant may also affect the relationship of daily carbon gain to current foliage production. The relationship of instantaneous single-leaf compensatory photosynthesis to the regrowth of foliage can be further complicated on longer time scales, requiring the consideration of the demography of plant parts (e.g. Bunce 1986, Olson and Richards 1988). The rate at which new leaves are produced and old leaves are lost will affect the relationship of single-leaf photosynthesis to long-term foliage regrowth because the long-term carbon benefit of a leaf is, in part, a function of leaf longevity (Mooney and Gulmon 1982).

Thus, the existence of single-leaf compensatory photosynthesis does not necessarily translate into compensatory increases in foliage production. However, in this study, compensatory photosynthesis at the canopy level

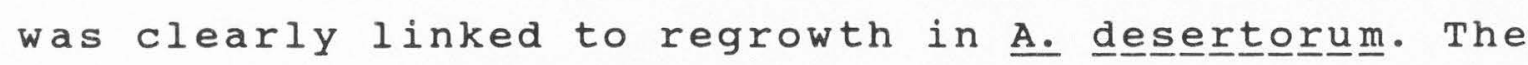
differences in compensatory photosynthesis of entire $\underline{A}$. desertoㅡㅁㅡ tussocks were expressed as differences in regrowth because foliage production was directly limited by current whole-plant assimilation. The effects of defoliation patterns on carbon gain and regrowth were associated with changes in whole-canopy properties (e.g. canopy structure and light interception; see Chapter IV) in addition to changes in the physiological activity of individual leaves (e.g. Nowak and Caldwell 1984). The photosynthetic response of any single leaf to defoliation 
would not necessarily have been representative of wholetussock carbon gain because of the changes in whole-canopy properties (Acock et al. 1978). Therefore, in my study, it is unlikely that regrowth would have corresponded as well with changes in single-leaf photosynthesis as it did with changes in whole-plant photosynthesis. 


\section{REFERENCES}

Acock B, Charles-Edwards DA, Fitter DJ, Hand DW, Ludwig LJ, Warren Wilson $J$, withers AC (1978) The contribution of leaves from different levels within a tomato crop to canopy net photosynthesis: an experimental examination of two canopy models. J Exp Bot 29:815-827

Amthor JS (1984) The role of maintenance respiration in plant growth. Plant Cell Envir 7:561-569

Archer S, Detling JK (1984) The effects of defoliation and competition on regrowth of tillers of two North American mixed-grass prairie graminoids. Oikos 43:351357

Atkinson CJ (1986) The effect of clipping on net photosynthesis and dark respiration rates of plants from an upland grassland, with reference to carbon partitioning in Festuca ovina. Ann Bot 58:61-72

Austin DD, Urness PJ, Riggs RA (1986) Vegetal change in the absence of livestock grazing, Mountain brush zone, Utah. J Range Manage 39:514-517

Balph DF, Malechek JC (1985) Cattle trampling of crested wheatgrass under short-duration grazing. J Range Manage $38: 226-227$

Batzli Go, white RG, Maclean SF Jr, Pitelka FA, collier BD (1980) The herbivore-based trophic system. In: Brown J, Miller PC, Tieszen LL, Bunnell FL (eds) An arctic ecosystem, the coastal tundra at Barrow, Alaska. US IBP synthesis series, vol 12, Dowden, Hutchinson and Ross Publ, stroudsburg, Penn, pp 335-410

Belsky AJ (1986) Does herbivory benefit plants ? A review of the evidence. Amer Natur 127:870-892

Bentley S, whittaker JB (1979) Effects of grazing by a

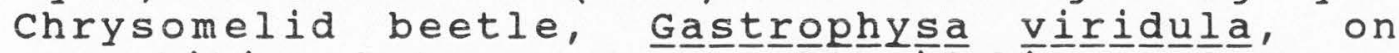

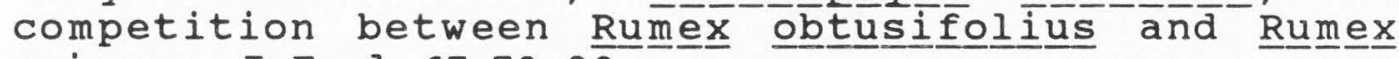
crispus. I Ecol $67: 79-90$

Binnie RC, Chestnut DMB, Murdoch JC (1980) The effect of time of initial defoliation and the height of defoliation on the productivity of perennial ryegrass swards. Grass For Sci 35:267-273

Biscoe PV, Gallagher JN, Littleton EJ, Monteith JL, Scott RK (1975) Barley and its environment IV. Sources of assimilate for the grain. J Appl Ecol 12:295-318 
Blocker HD (1977) The impact of invertebrates as herbivores on arid and semi-arid rangeland in the United states. In: The impact of herbivores on arid and semi-arid rangelands. Proc 2nd US/Aust Rangeland Panel. Aust Range Soc, Perth

Briske DD (1986) Plant response to defoliation : morphological considerations and allocation priorities. In: Joss PJ, Lynch PW, Williams OB (eds) Rangelands: a resource under siege. Proceedings of the 2 nd International Rangeland Congress. Australian Acad Sci, Canberra, pp 425-427

Brown RH, Cooper RB, Blaser RE (1966) Effects of leaf age on efficiency. Crop Sci 6:206-209

Bryant JP, Kuropat PJ (1980) Selection of winter forage by subarctic browsing vertebrates: the role of plant chemistry. Ann Rev Ecol Syst 11:261-285

Bunce JA (1986) Measurements and modeling of photosynthesis in field crops. In: CRC critical reviews in plant sciences. vol 4 issue 1, CRC Press, Boca Raton, FL, pp $47-77$

Caldwell MM (1984) Plant requirements for prudent grazing. In: Developing strategies for rangeland management. Westview Press, Boulder, CO, pp 117-152

Caldwell MM, Richards JH, Johnson DA, Nowak RS, Dzurec RS (1981) Coping with herbivory: photosynthetic capacity and resource allocation in two semiarid Agropyron bunchgrasses. Oecologia (Berlin) 50:14-24

Caldwell MM, Dean TJ, Nowak RS, Dzurec RS, Richards JH (1983a) Bunchgrass architecture, light interception, and water-use efficiency: assessment by fiber optic point quadrats and gas exchange. Oecologia (Berlin) $59: 178-184$

Caldwell MM, Harris GW, Dzurec RS (1983b) A fiber optic point quadrat system for improved accuracy in vegetation sampling. Oecologia (Berlin) 59:417-418

Caldwell MM, Meister H-P, Tenhunen JD, Lange OL (1986) Canopy structure, light microclimate and leaf gas

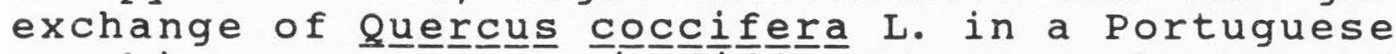
macchia: measurements in different canopy layers and simulations with a canopy model. Trees 1:25-41

Caldwell MM, Richards JH, Manwaring JH, Eissenstat DM (1987) Rapid shifts in phosphate acquisition show direct competition between neighbouring plants. Nature 327:615-616 
Capinera JL, Roltsch WJ (1980) Response of wheat seedlings to actual and simulated migratory grasshopper defoliation. J Econ Entomol 73:258-261

Chazdon RL, Field CB (1987) Photographic estimation of photosynthetically active radiation: evaluation of a computerized technique. Oecologia (Berlin) 73:525-532

Cook CW, stoddart LA (1953) some growth responses of crested wheatgrass following herbage removal. J Range Manage 6:267-270

Cook CW, Stoddart LA, Kinsinger FE (1958) Responses of crested wheatgrass to various clipping treatments. Ecol Mono 28:237-272

Coughenour MB (1984) A mechanistic simulation analysis of water use, leaf angles, and grazing in east African graminoids. Ecol Modelling 26:203-230

Coughenour MB, MCNaughton SJ, Wallace LL (1984) Modelling primary production of perennial graminoids - uniting physiological processes and morphometric traits. Ecol Modelling 23:101-134

Crawley MJ (1983) Herbivory: The dynamics of animal-plant interactions. Studies in ecology, vol 10, Blackwell Sci Publ, Boston

Davidson JL, Milthorpe FL (1966) The effect of defoliation on the carbon balance in Dactylis glomerata. Ann Bot $30: 185-198$

DeAngelis JD, Larson KC, Berry RE, Krantz GW (1982) Effects of spider mite injury on transpiration and leaf water status in peppermint. Environ Entomol 11:975-978

Detling JK, Dyer MI (1981) Evidence for potential growth regulators in grasshoppers. Ecology 62:485-488

Detling JK, Painter EL (1983) Defoliation responses of western wheatgrass populations with diverse histories of prairie dog grazing. Oecologia (Berlin) 57:65-71

Detling JK, Dyer MI, Winn DT (1979) Effect of simulated grasshopper grazing on $\mathrm{CO}_{2}$ exchange rates of western wheatgrass leaves. J Econ Entomol 72:403-406

Detling JK, Dyer MI, Procter-Gregg C, Winn DT (1980a) Plantherbivore interactions: examination of potential effects of bison saliva on regrowth of Bouteloloua gracilis. Oecologia (Berlin) 45:26-31 
Detling JK, Winn DT, Procter-Gregg C, Painter EL (1980b) Effects of simulated grazing by below-ground herbivores on growth, $\mathrm{CO}_{2}$ exchange, and carbon allocation patterns of Bouteloua gracilis. J Appl Ecol 17:771-778

Dirzo R (1984) Herbivory: a phytocentric overview. In: Dirzo $R$, Sarukhan $J$ (eds) Perspectives on plant population ecology. Sinauer Assoc, Sunderland, Mass, pp 141-165

Dirzo R, Harper JL (1982) Experimental studies on slug-plant interactions. III. Differences in the acceptability of individual plants of Trifolium repens to slugs and snails. J Ecol 70:101-117

Dixon WJ (1983) BMDP statistical software. 1983 printing, Univ of Calif Press, Berkeley

Dyer MI, Bokhari UG (1976) Plant-animal interactions: studies of the effects of grasshopper grazing on blue grama grass. Ecology 57:762-772

Dyer MI, Detling JK, Coleman DC, Hilbert DW (1982) The role of herbivores in grasslands. In: Estes JR, Tyrl RJ, Brunken JN (eds) Grasses and grasslands: systematics and ecology. Univ Oklahoma Press, Norman

Faeth SH (1985) Host leaf selection by leaf miners: interactions among three trophic levels. Ecology $66: 870-875$

Farrar RR, Bradley JR (1985) Within-plant distribution of Heliothis spp. (Lepidoptera: Noctuidae) eggs and larvae on cotton in North Carolina. Environ Entomol 14:205-209

Fitter AH, Hay RKM (1981) Environmental physiology of plants. Academic Press, New York

Fliervoet LM, werger MJA (1984) Canopy structure and microclimate of two wet grassland communities. New phytol 96:115-130

Gibson CWD, Brown VK, Jepsen M (1987) Relationships between the effects of insect herbivory and sheep grazing on seasonal changes in an early successional plant community. Oecologia (Berlin) 71:245-253

Geuns JCM (1978) Steroid hormones and plant growth and development. Phytochem 17:1-14

Gifford RM, Marshall C (1973) Photosynthesis and assimilate distribution in Lolium multiflorum Lam. following differential tiller defoliation. Aust J Biol Sci $26: 517-526$ 
Gifford RM, Jenkins CLD (1982) Prospects of applying knowledge of photosynthesis toward improving crop production. In: Govindjee A (ed) Photosynthesis: development, carbon metabolism and plant productivity. vol II, Academic Press, New York, pp 419-457

Gutschick VP, Barron MH, waechter DA, Wolf MA (1985) Portable monitor for solar radiation that accumulates irradiance histograms for 32 leaf-mounted sensors. Agric For Meteorol 33:281-290

Hammond RB, Pedigo LP (1981) Effects of artificial and insect defoliation on water loss from excised soybean leaves. J Kansas Entomol Soc 54:331-336

Hansen JD (1987) Feeding site selection by Irbisia pacifica (Hemiptera: Miridae) on four cool-season western range grasses. J Kansas Entomol Soc 60:316-323

Harper JL (1977) Population biology of plants. Academic Press, New York

Hartnett DC, Bazzaz FA (1986) Leaf demography and plantinsect interactions: a further comment. Amer Natur $127: 561-564$

Haws BA (1978) Economic impacts of Labops hesperius on the production of high quality range grasses. In: Final report of Utah Agric Exp stat to Four Corners Reg Comm. Utah State Univ, Logan

Heichel $\mathrm{GH}$, Turner NC (1983) $\mathrm{CO}_{2}$ assimilation of primary and regrowth foliage of red maple (Acer rubrum L.) and red

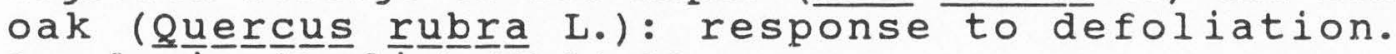
oecologia (Berlin) 57:14-19

Hewitt GB (1977) Review of forage losses caused by rangeland grasshoppers. US Dept Agric Misc Publ 1348, USDA, Washington, D.C.

Hodkinson ID, Hughes MK (1982) Insect herbivory. Outline studies in ecology. Chapman and Hall Publ, New York

Hyder DN (1972) Defoliation in relation to vegetative growth. In: Younger VB, MCKell CM (eds) Biology and utilization of grasses. Academic Press, New York, pp 304-317

Janzen DH (1979) New horizons in the biology of plant defenses. In: Rosenthal GA, Janzen DH (eds) Herbivores: their interaction with secondary plant metabolites. Academic Press, New York, pp 331-350 
Joern A (1982) Vegetation structure and microhabitat selection in grasshoppers (Orthoptera, Acrididae). SW Natur 27:197-209

Joggi D, Hofer U, Nasberger J (1983) Leaf area index, canopy structure and photosynthesis of red clover (Trifolium pratense L.). Plant Cell Envir 6:611-616

Johnson IR, Parsons AJ (1985a) A theoretical analysis of grass growth under grazing. J Theor Biol 112:345-367

Johnson IR, Parsons AJ (1985b) Use of a model to analyse the effects of continuous grazing managements on seasonal patterns of grass production. Grass For Sci 40:449-458

Johnson IR, Thornley JHM (1985) Dynamic model of the response of a vegetative grass crop to light, temperature and nitrogen. Plant Cell Envir 8:485-499

Jones HG (1983) Plants and microclimate. Cambridge Univ Press, Cambridge, pp 162-163

Kimmerer $T W$, potter DA (1987) Nutritional quality of specific leaf tissues and selective feeding by a specialist leafminer. Oecologia (Berlin) 71:548-551

King J, Grant SA, Torvell L, Sim EM (1984) Growth rate, senescence and photosynthesis of ryegrass swards cut to maintain a range of values for leaf area index. Grass For Sci 39:371-380

Koerner $\mathrm{C}(1982) \mathrm{CO}_{2}$ exchange in the alpine sedge Carex curvula as influenced by canopy structure, light and temperature. Oecologia (Berlin) 53:98-104

Koerner C, Woodward FI (1987) The dynamics of leaf extension in plants with diverse altitudinal ranges. II. Field studies in Poa species between 600 and $3200 \mathrm{~m}$ altitude. oecologia (Berlin) 72:279-283

Kulman HM (1965) Effects of artificial defoliation of pine on subsequent shoot and needle growth. Forest Sci $11: 90-98$

Leafe E (1972) Micro-environment, carbon dioxide exchange and growth in grass swards. In: Rees A, Cockshull K, Hand D, Hurd R (eds) Crop processes in controlled environments. Academic Press, London, pp 157-174

Lincoln DE, Mooney HA (1984) Herbivory on Dịplacuㅗㅗ aurantiacus shrubs in sun and shade. Oecologia (Berlin) $64: 173-176$ 
Lubchenco $J$ (1978) Plant species diversity in a marine intertidal community: importance of herbivore food preference and algal competitive abilities. Amer Natur $112: 23-29$

Ludlow MM, Charles-Edwards DA (1980) Analysis of regrowth of a tropical grass/legume sward subjected to different frequencies and intensities of defoliation. Aust $J$ Agric Res 31:673-692

Ludlow MM, Stobbs TH, Davis R, Charles-Edwards DA (1982) Effect of sward structure of two tropical grasses with contrasting canopies on light distribution, net photosynthesis and size of bite harvested by grazing cattle. Aust J Agric Res 33:187-201

Macnicol PK (1976) Rapid changes in the wounding response of leaf discs following excision. Plant Physiol 57:80-84

Marsh R, Campling RC (1970) Fouling of pastures by dung. Herb Abstr 40:123-130

Marshall C, Sagar GR (1965) The influence of defoliation on the distribution of assimilates in Lolium multiflorum Lam. Ann Bot 29:365-370

McKey D (1979) The distribution of secondary compounds within plants. In: Rosenthal GA, Janzen DH (eds) Herbivores: their interaction with secondary plant metabolites. Academic Press, New York, pp 56-134

MCNaughton SJ (1979a) Grazing as an optimization process: grass-ungulate relationships in the serengeti. Amer Natur 113:691-703

McNaughton SJ (1979b) Grassland-herbivore dynamics. In: Sinclair ARE, Norton-Griffiths $M$ (eds) Serengeti, dynamics of an ecosystem. Univ Chicago Press, Chicago, pp 46-81

MCNaughton SJ (1983) Compensatory plant growth as a response to herbivory. Oikos 40:329-336

MCNaughton SJ (1986) On plants and herbivores. Amer Natur $128: 765-770$

McNaughton SJ, Wallace LL, Coughenour MB (1983) Plant adaptation in an ecosystem context: effects of defoliation, nitrogen, and water on the growth of an African $\mathrm{C}_{4}$ sedge. Ecology $64: 307-318$

MCNaughton SJ, Tarrants JL, McNaughton MM, Davis RH (1985) silica as a defense against herbivory and a growth promoter in African grasses. Ecology 66:528-535 
Mendoza A, Pinero D, Sarukhan J (1987) Effects of experimental defoliation on growth, reproduction and survival of Astrocaryum mexicanum. J Ecol 75:545-554

Monsi M, Uchijima Z, oikawa T (1973) structure of foliage canopies and photosynthesis. Ann Rev Ecol Syst 4: 301327

Mooney HA, Gulmon SL (1982) Constraints on leaf structure and function in reference to herbivory. Bioscience $32: 198-206$

Mueggler WF (1972) Influence of competition on the response of bluebunch wheatgrass to clipping. J Range Manage $25: 88-92$

Norton BE, Johnson PS (1983) Pattern of defoliation by cattle grazing crested wheatgrass pastures. In: Smith JA, Hays VW (eds) Proceedings of the XIV International Grassland Congress, Westview Press, Boulder, Colo, pp $462-464$

Norton BE, Johnson PS (1986) Impact of grazing on crested wheatgrass in relation to plant size. In: Johnson KL (ed) Crested wheatgrass: its values, problems and myths; symposium proceedings. Utah State Univ, Logan, Utah, pp 275-279

Nowak RS, Caldwell MM (1984) A test of compensatory photosynthesis in the field: implications for herbivory tolerance. Oecologia (Berlin) 61:311-318.

Nowak RS, Caldwell MM (1986) Photosynthetic characteristics of crested wheatgrass and bluebunch wheatgrass. J Range Manage 39:443-450

Olson BE (1986) Tiller dynamics of Agropyron desertorum in response to grazing and resource manipulation. PhD dissertation, Utah State Univ, Logan

Olson BE, Richards JH (1988) Tussock regrowth after grazing: intercalary meristem and axillary bud activity of tillers of Agropyron desertorum. Oikos 51:(in press)

Ostlie KR, Pedigo LP (1984) Water loss from soybeans after simulated and actual insect defoliation. Environ Entomol 13:1675-1680

Owen DF, wiegert RG (1981) Mutualism between grasses and grazers: an evolutionary hypothesis. Oikos 36:376-378 
Paige KN, Whitham TG (1987) overcompensation in response to mammalian herbivory: the advantage of being eaten. Amer Natur 129:407-416

Parsons AJ, Leafe EL, collett B, Penning PD, Lewis J (1983) The physiology of grass production under grazing. II. Photosynthesis, crop growth and animal intake of continuously-grazed swards. J Appl Ecol 20:127-139

Provenza FD, Malechek JC (1984) Diet selection by domestic goats in relation to blackbrush twig chemistry. J Appl ECol 21:831-841

Reardon PO, Leinweber CL, Merrill LB (1974) Response of sideoats grama to animal saliva and thiamine. J Range Manage 27:400-401

Rhodes I (1969) The yield, canopy structure and light interception of two ryegrass varieties in mixed culture and monoculture. J Br Grassland Soc 24:123-127

Rhodes I (1971) The relationship between productivity and some components of canopy structure in ryegrass (Lolium spp.). II. Yield, canopy structure and light interception. J Agric Sci, Cambridge 77:283-292

Richards JH (1984) Root growth response to defoliation in two Agropyron bunchgrasses: field observations with an improved root periscope. Oecologia (Berlin) 64:21-25

Richards JH, Caldwell MM (1985) Soluble carbohydrates, concurrent photosynthesis and efficiency in regrowth following defoliation: a field study with Agropyron species. J Appl Ecol 22:907-920

Ryle GJA, Powell CE (1975) Defoliation and regrowth in the graminaceous plant: the role of current assimilate. Ann Bot 39:297-310

Sackston WE (1959) Effect of artificial defoliation on sunflowers. Can J Plant Sci 39:108-118

Salihi DO, Norton BE (1987) Survival of perennial grass seedlings under intensive grazing in semi-arid rangelands. J Appl Ecol 24:145-151

Sheehy JE (1977) Microclimate, canopy structure and photosynthesis in canopies of three contrasting temperate forage grasses. III. Canopy photosynthesis, individual leaf photosynthesis, and the distribution of current assimilate. Ann Bot 41:593-604

Smith E (1937) The influence of light and carbon dioxide on photosynthesis. Gen Physiol 20:807-830 
Stanton NL (1983) The effect of clipping and phytophagous nematodes on net primary production of blue grama, Bouteloua gracilis. Oikos 40:249-257

Stickler FC, Pauli AW (1961) Leaf removal in grain sorghum. I. Effects of certain defoliation treatments on yield and components of yield. Agron J 53:99-102

Stowe BB, Hudson VW (1969) Growth promotion in pea stem sections. III. By alkyl nitriles, alkyl acetylenes and insect juvenile hormones. Plant Physiol 44:1051-1057

Sugiyama S, Yoneyama M, Takahashi N, Gotoh K (1985) Canopy structure and productivity of Festuca a arundinacea schreb. swards during vegetative and reproductive growth. Grass For Sci 40:49-55

Tenhunen JD, Weber JA, Yocum CS, Gates DM (1976) Development of a photosynthesis model with an emphasis on ecological applications. II. Analysis of a data set describing the $\mathrm{P}_{\mathrm{m}}$ surface. Oecologia (Berlin) 26:101119

Tenhunen JD, Lange OL, Gebel J, Beyschlag W, Weber JA (1984) Changes in photosynthetic capacity, carboxylation efficiency, and $\mathrm{CO}_{2}$ compensation point associated with midday stomatal closure and midday depression of net

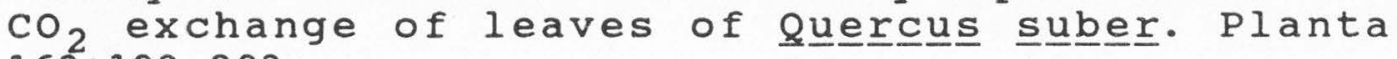
$162: 193-203$

Thompson JN (1983) Selection of plant parts by Depressia multifidae (Lep., Oecophoridae) on its seasonally restricted host plant, Lomatium grayi (Umbelliferae). Ecol Entomol 8:203-211

Thornley JHM (1976) Mathematical models in plant physiology. Academic Press, New York

Todd JG, Kamm JA (1974) Biology and impact of a grass bug Labops hesperius Uhler in oregon rangeland. J Range Manage 27:453-458

voncaemmerer S, Farquhar GD (1981) some relationships between the biochemistry of photosynthesis and the gas exchange of leaves. Planta 153:376-387

Walker GP, Aitken DCG (1985) Oviposition and survival of bayberry whitefly, Parabemisia myricae (Homoptera: Aleyrodidae) on lemons as a function of leaf age. Environ Entomol 14:254-257 
Wallace LL, MCNaughton SJ, Coughenour MB (1984) Compensatory photosynthetic responses of three African graminoids to different fertilization, watering and clipping regimes. Bot Gaz 145:151-156

Walmsley MR, Capinera JL, Detling JK, Dyer MI (1987) Growth of blue grama and western wheatgrass following grasshopper defoliation and mechanical clipping. J Kansas Entomol Soc 60:51-57

Wambolt CL, Kelsey RG, Personius TL, striby KD, MCNeal AF, Havstad KM (1987) Preference and digestibility of three big sagebrush subspecies and black sagebrush as related to crude terpernoid content. In: Provenza FD, Flinders JT, MCArthur ED (eds) Proceedings- symposium on plantherbivore interactions. Snowbird, Utah, Aug 7-9, 1985, US Forest Service, Intermountain Res Station, Gen Tech Rep INT-222, Logan, Utah, pp 71-73

Warren SD, Thurow TL, Blackburn WH, Garza NE (1986) The influence of livestock trampling under intensive rotation grazing on soil hydrologic characteristics. J Range Manage 39:491-495

Warren Wilson J (1960) Inclined point quadrats. New Phytol $59: 1-8$

Warren Wilson $J$ (1963) Estimation of foliage denseness and foliage angle by inclined point quadrats. Aust $J$ Bot $11: 95-105$

Watson MA, Casper BB (1984) Morphogenetic constraints on patterns of carbon distribution in plants. Ann Rev Ecol Syst 15:233-258

Welker JM, Rykiel EJ Jr, Briske DD, Goeschl JD (1985) Carbon import among vegetative tillers within two bunchgrasses: assessment with carbon-11 labelling. oecologia (Berlin) 67:209-212

Whitfield GH, Carruthers RI, Lampert EP, Haynes DL (1985) spatial and temporal distribution of plant damage caused by the onion maggot (Diptera: Anthomyiidae). Environ Entomol 14:262-266

Woledge $J$ (1972) The effect of shading on the photosynthetic rate and longevity of grass leaves. Ann Bot 36:551-561

Woledge $J$ (1977) The effects of shading and cutting treatments on the photosynthetic rates of ryegrass leaves. Ann Bot 41:1279-1286 
Woledge $J$ (1986) The effect of age and shade on the photosynthesis of white clover leaves. Ann Bot 57:257262

Woledge $J$, Leafe EL (1976) Single leaf and canopy photosynthesis in a ryegrass sward. Ann Bot 40:773-783

Woledge J, Parsons AJ (1986a) The effect of temperature on the photosynthesis of ryegrass canopies. Ann Bot $57: 487-497$

Woledge $J$, Parsons AJ (1986b) Temperate grasslands. In: Baker NR, Long SP (eds) Photosynthesis in contrasting environments. Elsevier Science Publishers, New York, New York, pp 173-197

Yabann WK, Burritt EA, Malechek JC (1987) Sagebrush (Artemisia tridentata) monoterpenoid concentrations as factors in diet selection by free-grazing sheep. In: Provenza FD, Flinders JT, McArthur ED (eds) Proceedings- symposium on plant-herbivore interactions. Snowbird, Utah, Aug 7-9, 1985, US Forest Service, Intermountain Res Station, Gen Tech Rep INT-222, Logan, Utah, pp 71-73

Zahorik DM, Haupt KA (1977) The concept of nutritional wisdom: applicability of laboratory learning models to large herbivores. In: Barker LM, Best MR, Domjan M (eds) Learning mechanisms in food selection. Baylor Univ Press, Waco, Texas, pp 45-67. 
APPENDIX 


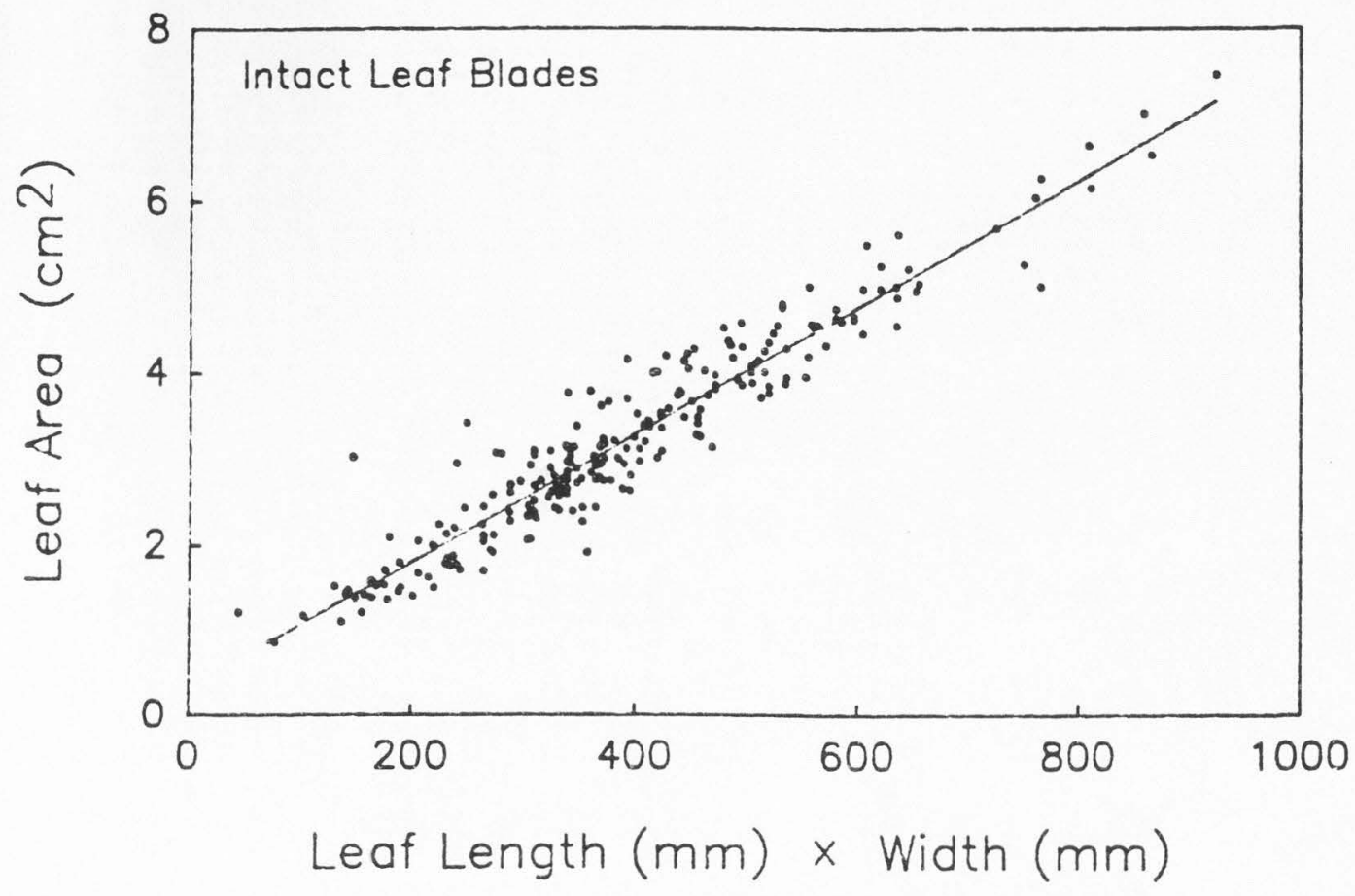

9. 20. Leaf blade area (one side) as a function of the pduct of blade length and maxjmum width for intact leaf ades $\left(y=0.327+0.00741 x ; r^{2}=.91 ; n=234\right)$. Intact af blades were those which had unrolled lamina and were clipped. 


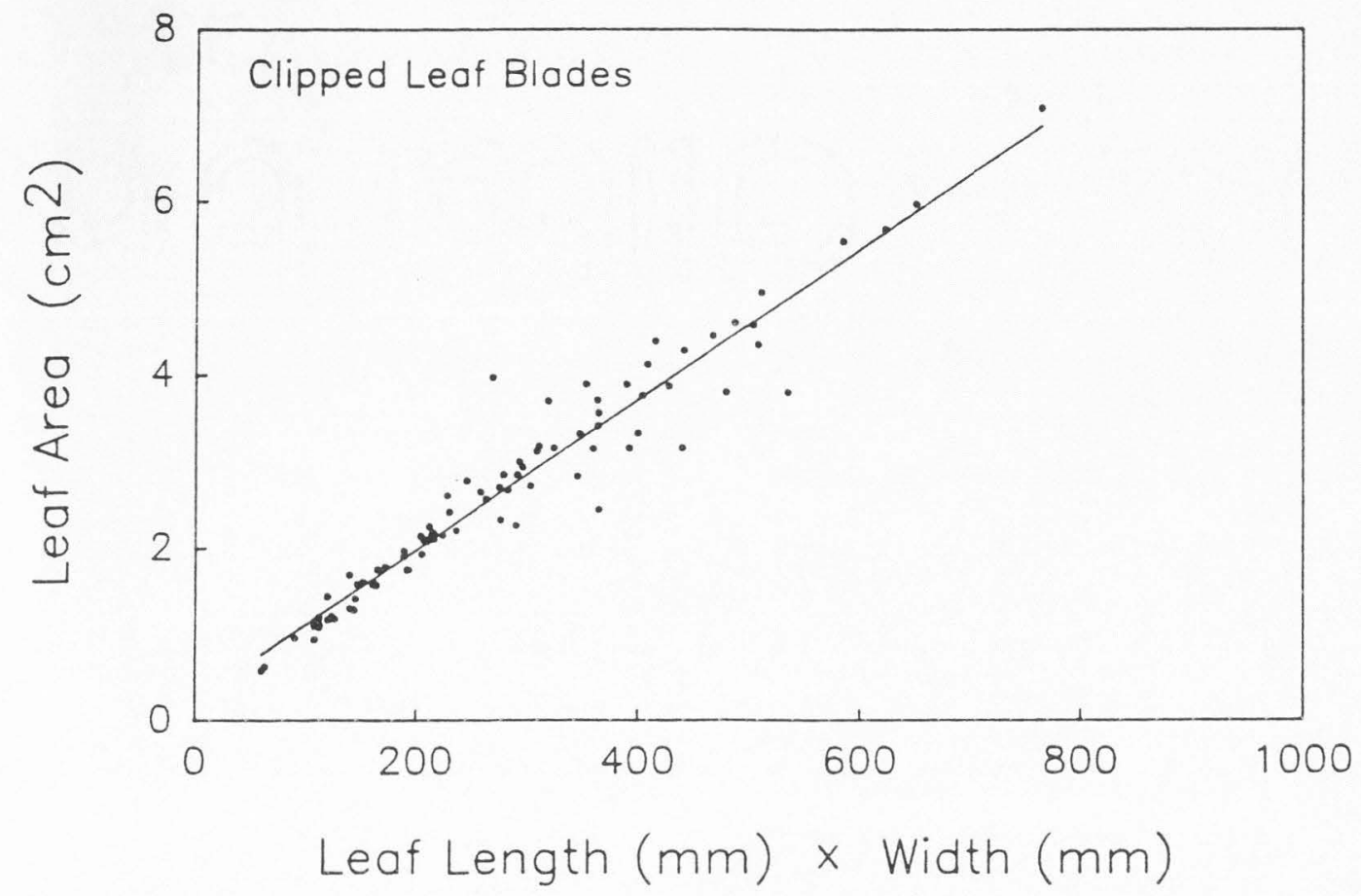

Fig. 21. Leaf blade area (one side) as a function of the product of blade length and maximum width for clipped leaf blades $\left(y=0.247+0.00866 x ; r^{2}=.94 ; n=86\right)$. Clipped blades were those which had unrolled lamina and were partially defoliated. 


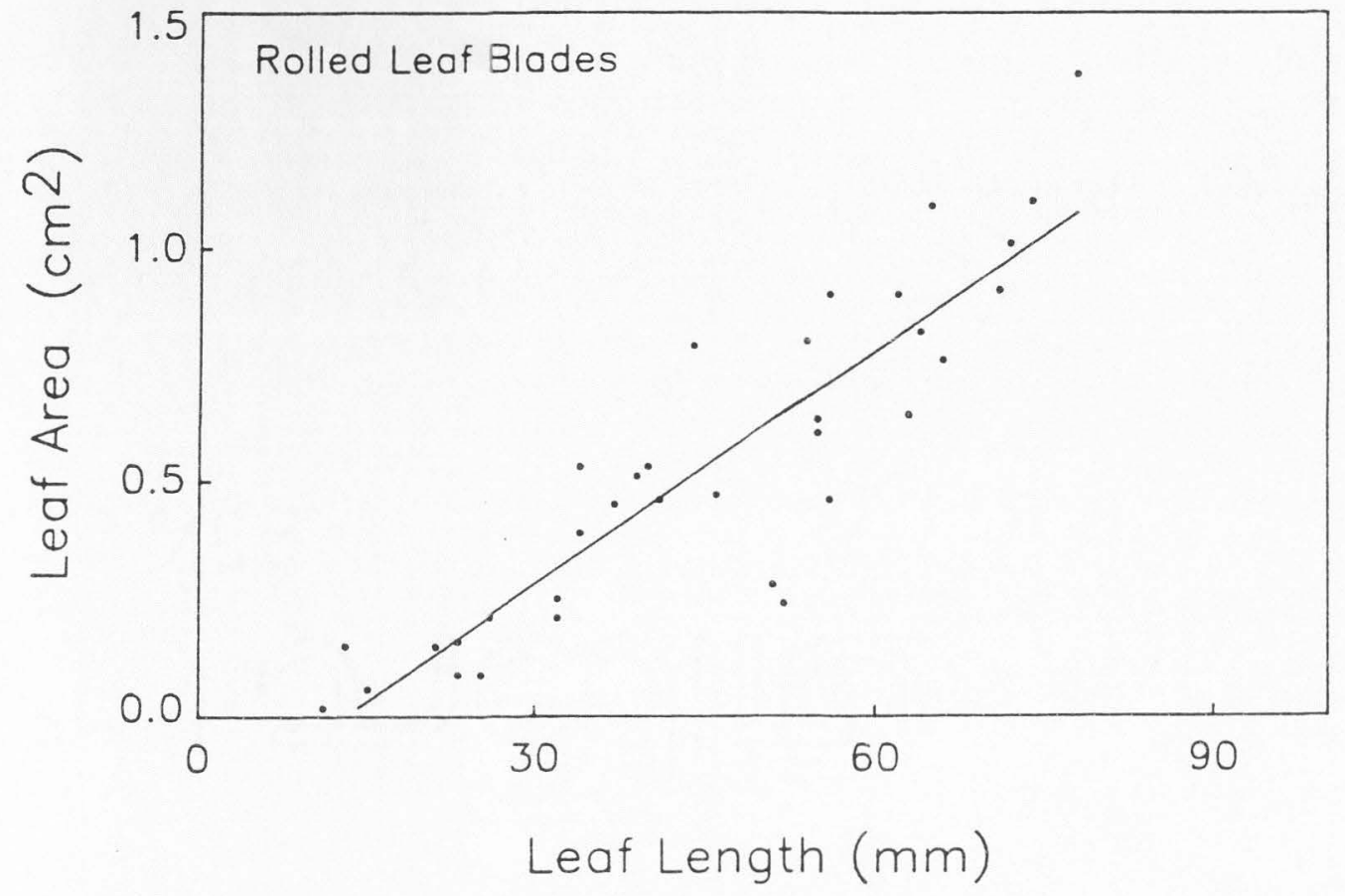

Fig. 22. Leaf blade area (one side) as a function of blade length for rolled leaf blades $(y=-0.214+.0165 x$; $r^{2}=.80 ; n=34$ ). 
VITA

\author{
Warren Glenn Gold \\ Candidate for the Degree of \\ Doctor of Philosophy
}

Dissertation: The Effects of the spatial Pattern of Defoliation on Regrowth of a Tussock Grass

Major Field: Range Ecology

Biographical Information:

Personal Data: Born at Chicago, Illinois, September 29, 1957, son of Raymond and Judith Gold; married Julia Wisselmann December 30, 1985.

Education: Attended Hanford High School, graduated 1975; received Bachelor of Arts degree in Zoology from the University of Washington, 1980; received Bachelor of Science degree in Botany from the University of Washington, 1980; received Master of Science degree in Range Ecology from Utah state University, 1983; completed requirements for the Doctor of Philosophy degree at Utah state University in January 1988, with a major in Range Ecology and area of specialization of plant physiological ecology.

Professional Experience: Utah State University graduate fellow in the Department of Range Science, 19801981; National Science Foundation graduate fellow in the Department of Range Science, Utah state University, 1981-1984; graduate research assistant in the Department of Range Science, Utah state University, 1984-1988. 